Global Cropland-Extent Product at 30-m Resolution (GCEP30) Derived from Landsat Satellite Time-Series Data for the Year 2015 Using Multiple Machine-Learning Algorithms on Google Earth Engine Cloud

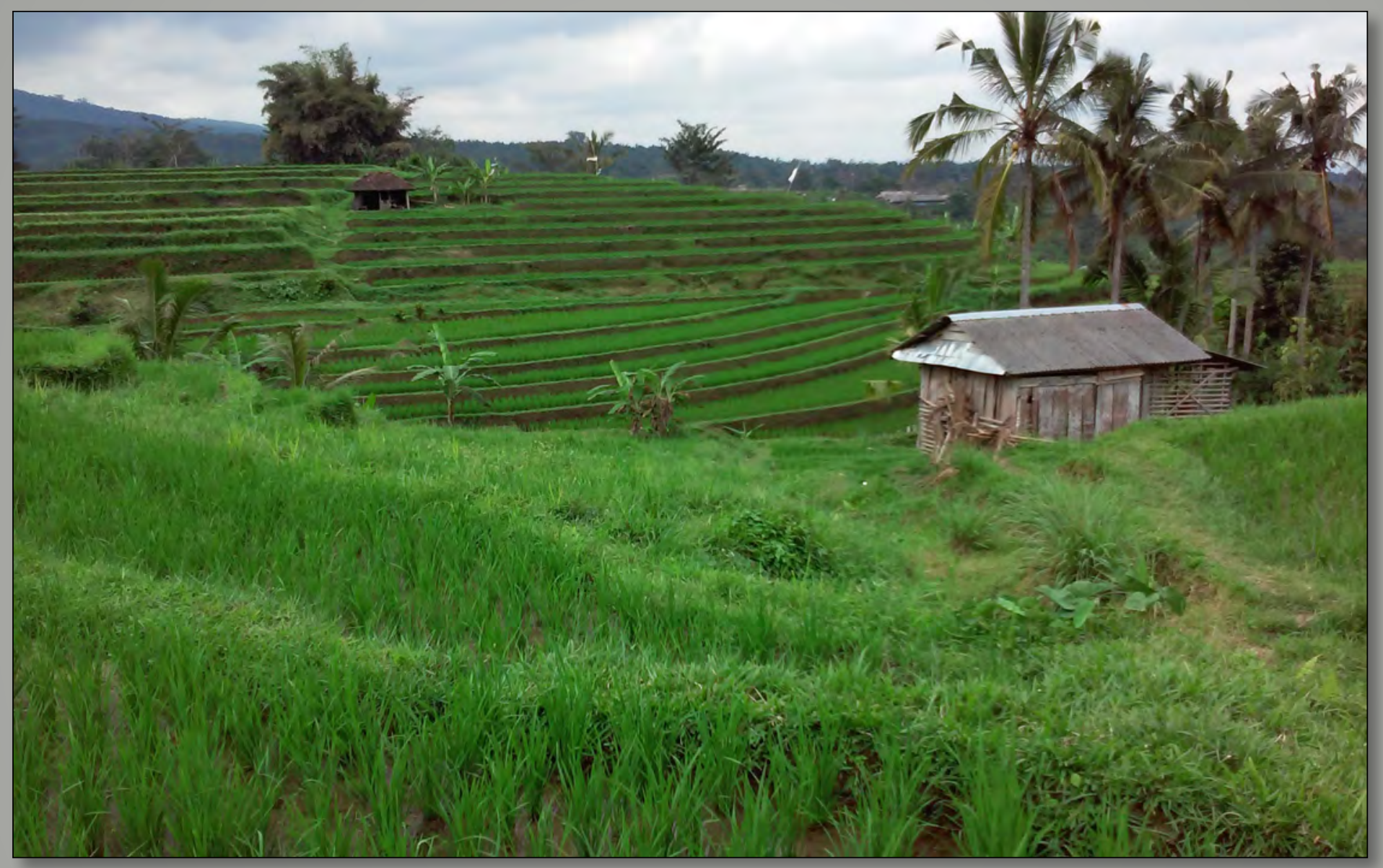

Professional Paper 1868

U.S. Department of the Interior U.S. Geological Survey 
Cover. Terraced rice fields of Jatiluwihkawan, Bali, Indonesia. Photograph by Prasad Thenkabail, U.S. Geological Survey, 2016. 


\section{Global Cropland-Extent Product at 30-m Resolution (GCEP30) Derived from Landsat Satellite Time-Series Data for the Year 2015 Using Multiple Machine-Learning Algorithms on Google Earth Engine Cloud}

By Prasad S. Thenkabail, Pardhasaradhi G. Teluguntla, Jun Xiong, Adam Oliphant, Russell G. Congalton, Mutlu Ozdogan, Murali Krishna Gumma, James C. Tilton, Chandra Giri, Cristina Milesi, Aparna Phalke, Richard Massey, Kamini Yadav, Temuulen Sankey, Ying Zhong, Itiya Aneece, and Daniel Foley

Professional Paper 1868 


\section{U.S. Geological Survey, Reston, Virginia: 2021}

For more information on the USGS—-the Federal source for science about the Earth, its natural and living resources, natural hazards, and the environment-visit https://www.usgs.gov or call 1-888-ASK-USGS (1-888-275-8747).

For an overview of USGS information products, including maps, imagery, and publications, visit https://store.usgs.gov.

Any use of trade, firm, or product names is for descriptive purposes only and does not imply endorsement by the U.S. Government.

Although this information product, for the most part, is in the public domain, it also may contain copyrighted materials as noted in the text. Permission to reproduce copyrighted items must be secured from the copyright owner.

Suggested citation:

Thenkabail, P.S., Teluguntla, P.G., Xiong, J., Oliphant, A., Congalton, R.G., Ozdogan, M., Gumma, M.K., Tilton, J.C., Giri, C., Milesi, C., Phalke, A., Massey, R., Yadav, K., Sankey, T., Zhong, Y., Aneece, I., and Foley, D., 2021, Global cropland-extent product at 30-m resolution (GCEP30) derived from Landsat satellite time-series data for the year 2015 using multiple machine-learning algorithms on Google Earth Engine cloud: U.S. Geological Survey Professional Paper 1868, 63 p., https://doi.org/10.3133/pp1868.

Associated data for this publication:

U.S. Geological Survey and National Aeronautics and Space Administration, 2017, Release of GFSAD 30 meter cropland extent products: U.S. Geological Survey-National Aeronautics and Space Administration Land Processes Distributed Active Archive Center website, accessed June 2021 at https://Ipdaac.usgs.gov/news/release-of-gfsad-30meter-cropland-extent-products/.

ISSN 2330-7102 (online) 


\section{Acknowledgments}

The authors are grateful for the funding received from National Aeronautics and Space Administration's (NASA's) Making Earth System Data Records for Use in Research Environments (MEaSUREs) through NASA Research Opportunities in Space and Earth Science solicitation (June 1, 2013-May 31, 2018). This funding was received through NASA MEaSUREs project grant number NNH13AV82I and U.S. Geological Survey (USGS) sales order number 29039. The USGS provided significant direct and indirect supplemental funding through its National Land Imaging and Land Change Science programs, as well as support from the USGS Land Resources Mission Area, now part of the USGS Core Science Systems. Field work was conducted by various members of the team (Dr. Murali Krishna Gumma [International Crops Research Institute for the Semi-Arid Tropics], Dr. Pardhasaradhi Teluguntla [USGS; Bay Area Environmental Research Institute], Adam Oliphant [USGS], and Dr. Prasad Thenkabail [USGS]). We are thankful for the field support received from persons in various countries: from Dr. Rizatus Shofiyati, Dr. Dedi Nursyamsi, Dr. Wahayu Supriyatna, and Dr. Mochi Sikandar, Indonesian Ministry of Agriculture; Dr. Alfredo Huete, University of Technology, Sydney, Australia; and Dr. Rishiraj Dutta and Dr. Senaka Basnayake, Asian Disaster Preparedness Center. Our thanks go to those who provided us with valuable statistical and other data for comparison with cropland area statistics derived from remote sensing: Dr. Felix T. Portmann and Dr. Stefan Siebert, University of Göttingen, Germany; Dr. Peng Gong, University of California at Berkeley; and Dr. Ryutaro Tateishi, Center for Environmental Remote Sensing, Chiba University, Japan. The global rainfed, irrigated, and paddy cropland data at 500-m resolution (GRIPC500) produced by Dr. Meghan Salmon and Dr. Mark Friedl, Boston University, and others, were used for comparison purposes. Dr. Fabio Grita and Dr. Michela Marinelli, Food and Agricultural Organization of the United Nations (FAO), are acknowledged for their inputs and discussions on their Country Statistics data. We would like to thank Tyler Erickson and Noel Gorelick, Google Inc., for their collaboration in the global food-security support-analysis data (GFSAD) project, especially their participation in some of our biannual workshops held in different parts of the United States; they also provided many insights, as well as special higher speed access to Google Earth Engine. We would like to thank Susan P. Benjamin, Larry Gaffney, David Penisten, and Emily Yamamoto (all USGS) for their support and encouragement. We fondly remember with gratitude the late Edwin Pfiefer (USGS) for his enthusiastic support in the early days of this project. We thank Dr. Thomas Loveland (USGS, retired) and Dr. Trent Biggs (San Diego State University) for their critical reviews and comments on the initial version of the manuscript. Finally, authors would like to thank Taryn Lindquist (USGS) for her outstanding editing.

This is a very large global project run over many years. Many people from around the world have made suggestions or provided other valuable data and suggestions that helped this project in various ways. Our sincere apologies for not listing all important contributions, as it was simply infeasible. 


\section{Contents}

Acknowledgments ……......................................................................................................................ii

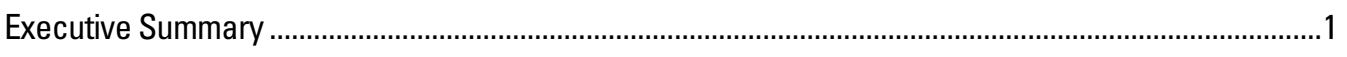



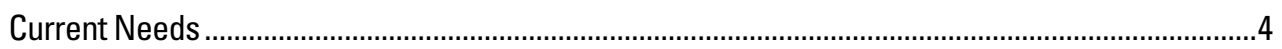

Existing Global Cropland-Extent Products..............................................................................

Technical Advances in Global Cropland-Extent Product...............................................................

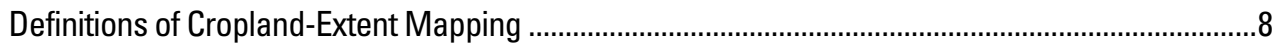



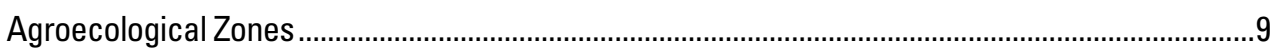

Landsat 30-m-Resolution Time-Series Data—Establishing Analysis-Ready Data (ARD) Cubes ......9

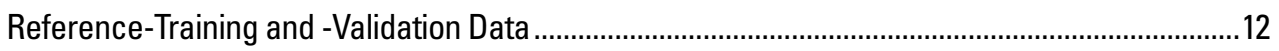

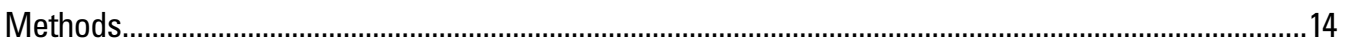

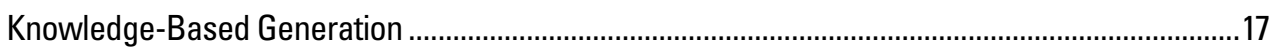

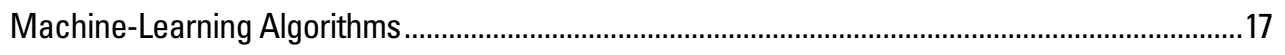

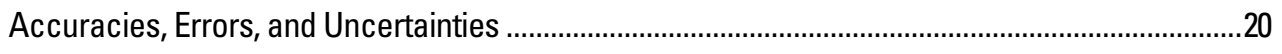

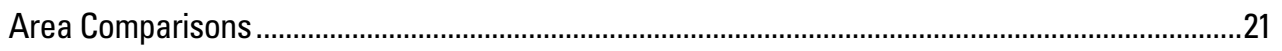

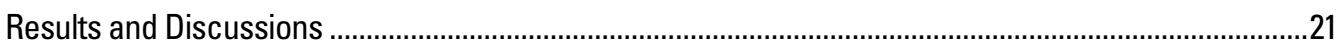

Global Cropland-Extent Map at 30-m Resolution (GCEP30) Derived from Landsat.........................21

Accuracies, Errors, and Uncertainties of Global Cropland-Extent Map at 30-m Resolution

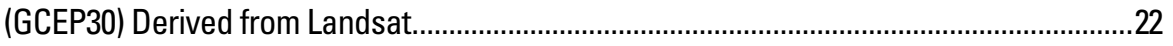

Cropland Areas of the World Derived from GCEP30 ....................................................................28

Cropland Areas of the Countries, Territories, Departments, and Regions Derived from

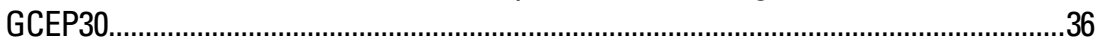

Cropland Areas of the Countries, Territories, Departments, and Regions in Different Continents Derived from GCEP30..............................................................................37

Comparison of GCEP30-Derived Cropland Areas by Continent with Cropland Areas from Other

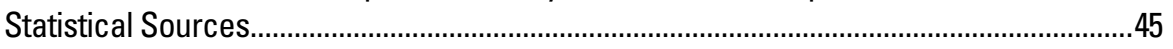

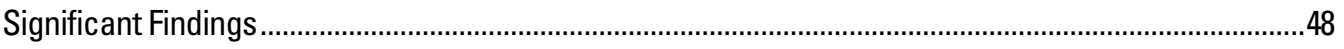

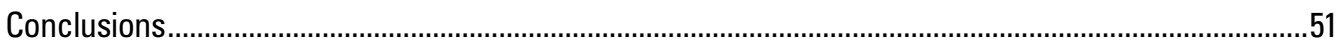

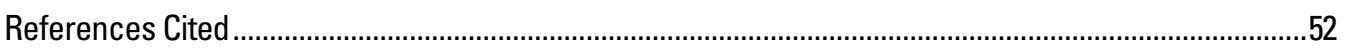

\section{Figures}

1. Photographs and Google Earth imagery showing examples of land covers in Uttar Pradesh, India, which are represented as agricultural cropland in cropland land-cover class, in global cropland-extent product at 30-m resolution (GCEP30) for nominal-year 2015...........................

2. Map showing agroecological zones used in this study .............................................10

3. Diagram illustrating how Landsat $30-\mathrm{m}$ resolution megafile data cube is compiled; example is from region of Australia and New Zealand .................................................10

4. Map showing locations of about 120,000 reference-training and -validation data samples used for machine-learning algorithms and cropland-extent-product validation.....................13

5. Two examples that show how primary spectral-reflectance data can be used to separate croplands from noncroplands: $A$, Plots of spectral-reflectance data across two crop-growing seasons in selected areas in Africa, and $B$, Graph showing profiles of spectral-reflectance time-series signatures of cropland and noncropland, as obtained from different spectral bands across same four seasons in same calendar year 
6. Two examples that show how transformations of spectral-reflectance data can be used to separate croplands from noncroplands: $A$, Screen capture of data portal that provides web access for downloading reference-training and -validation datasets used in machine-learning algorithms, and $B$, Two-dimensional scatter plot showing principal component 2 versus principal component 1 values of spectral-band reflectivity of cropland and noncropland.....

7. Map of global cropland-extent product at 30-m resolution (GCEP30) for nominal-year 2015, showing global distribution of cropland versus noncropland and percentages of cropland and noncropland out of total global cropland area.

8. Screen captures of close-up views of global cropland-extent product at 30-m resolution (GCEP30), showing distribution of cropland as mapped on very high resolution imagery in Paardenberg, South Africa; near Laguna Las Tunas Grandes, Argentina; and in Aksu Prefecture, China...

9. Map showing overall accuracies of agroecological zones for nominal-year 2015, derived from global cropland-extent product at 30-m resolution (GCEP30)...

10. Map showing producer's accuracies of cropland in global cropland-extent product at 30-m resolution (GCEP30) for all 74 agroecological zones.

11. Map showing user's accuracies of cropland in global cropland-extent product at $30-\mathrm{m}$ resolution (GCEP30) for all 74 agroecological zones...

12. Map showing cropland area by continent, calculated using global cropland-extent product at 30-m resolution (GCEP30) for nominal-year 2015, and percentages of cropland area by continent out of total global cropland area .

13. Map showing cropland versus noncropland area by agroecological zone, calculated using global cropland-extent product at 30-m resolution (GCEP30) for nominal-year 2015, and percentages of cropland and noncropland areas out of total global cropland area..

14. Screen captures of close-up views of cropland areas mapped near Rio Paraná, Brazil; Rānchi, India; and Tashkent, Uzbekistan.

15. Map showing net-cropland area by country, as percentage of total global net cropland area, calculated using global cropland-extent product at 30-m resolution (GCEP30) for nominal-year 2015

16. Map showing net-cropland area by country, as percentage of total geographic area of country, calculated using global cropland-extent product at 30-m resolution (GCEP30) for nominal-year 2015.

17. Map showing net-cropland area, in hectares per person, by country, derived using global cropland-extent product at 30-m resolution (GCEP30) for nominal-year 2015.....38

18. Graph comparing net-cropland areas for various countries, showing their areas derived from global cropland-extent product at 30-m resolution (GCEP30) for nominal-year 2015 versus those from Food and Agricultural Organization of the United Nations

19. Graph comparing net-cropland areas for various countries, showing their areas derived from global cropland-extent product at 30-m resolution (GCEP30) for nominal-year 2015 versus those from monthly irrigated and rainfed crop areas (MIRCA) database statistics....46

20. Graph comparing subnational net-cropland areas within various countries, showing areas derived from global cropland-extent product at 30-m resolution (GCEP30) for nominal-year 2015 versus those from national statistics provided by various national agencies.

21. Graph comparing net-cropland areas for districts in India, showing areas derived from global cropland-extent product at 30-m resolution (GCEP30) for nominal-year 2015 versus those from India districts' statistics

22. Screen captures of close-up views of cropland areas mapped in China (east of Weifang; north of Shuozhou; and southeast of Changde), illustrating some causes of cropland decreases in China

23. Screen captures of close-up views of cropland areas mapped in India (Rajasthan; Chhattisgarh; and Kerala), illustrating some causes of cropland increases in India .......51 


\section{Tables}

1. State-of-the-art global cropland-extent mapping products, derived using satellite-image remote sensing.

2. Landsat 30-m-resolution analysis-ready data (ARD) cubes composed for different regions of the world

3. Example of an accuracy confusion error matrix, which has been developed for each of 74 agroecological zones for assessing accuracies of cropland classification so that accuracies can be understood locally as well as globally..

4. Accuracy confusion error matrix for entire global cropland-extent map at 30-m resolution (GCEP30), used for assessing accuracies of cropland classification so that accuracies can be understood locally as well as globally....

5. Accuracy confusion error matrix for global cropland-extent map of Africa, used for assessing accuracies of cropland classification so that accuracies can be understood locally as well as globally.....

6. Accuracy confusion error matrix for global cropland-extent map of Australia, used for assessing accuracies of cropland classification so that accuracies can be understood locally as well as globally...

7. Accuracy confusion error matrix for global cropland-extent map of China, used for assessing accuracies of cropland classification so that accuracies can be understood locally as well as globally...

8. Accuracies of all 74 agroecological zones for global cropland-extent product at $30-\mathrm{m}$ resolution (GCEP30).

9. Cropland areas, by continent, derived from Landsat 30-m-resolution global cropland-extent map for nominal-year 2015.

10. Comparison of cropland areas derived from Landsat 30-m-resolution global cropland-extent map with other measured cropland areas.....

11. Cropland areas for countries, territories, departments, and regions in Africa, derived from Landsat 30-m-resolution global cropland-extent map..

12. Cropland areas for countries, territories, departments, and regions in Asia, derived from Landsat 30-m-resolution global cropland-extent map.

13. Cropland areas for countries, territories, departments, and regions in Australia and Oceania, derived from Landsat 30-m-resolution global cropland-extent map.

14. Cropland areas for countries, territories, departments, and regions in South America, derived from Landsat 30-m-resolution global cropland-extent map ...

15. Cropland areas for countries, territories, departments, and regions in Europe, derived from Landsat 30-m-resolution global cropland-extent map.

16. Cropland areas for countries, territories, departments, and regions in North America, derived from Landsat 30-m-resolution global cropland-extent map.

17. Net and percentage changes in cropland area and population between years 2000 and 2015 in the 10 largest countries in terms of cropland area. 


\section{Conversion Factors}

International System of Units to U.S. customary units

\begin{tabular}{|c|c|c|}
\hline Multiply & By & To obtain \\
\hline \multicolumn{3}{|c|}{ Length } \\
\hline meter (m) & 3.281 & foot (ft) \\
\hline kilometer (km) & 0.6214 & mile (mi) \\
\hline \multicolumn{3}{|c|}{ Area } \\
\hline hectare (ha) & 2.471 & acre \\
\hline square meter $\left(\mathrm{m}^{2}\right)$ & 0.0002471 & acre \\
\hline square meter $\left(\mathrm{m}^{2}\right)$ & 10.76 & square foot $\left(\mathrm{ft}^{2}\right)$ \\
\hline hectare (ha) & 0.003861 & square mile $\left(\mathrm{mi}^{2}\right)$ \\
\hline square kilometer $\left(\mathrm{km}^{2}\right)$ & 0.3861 & square mile $\left(\mathrm{mi}^{2}\right)$ \\
\hline \multicolumn{3}{|c|}{ Mass } \\
\hline kilogram (kg) & 2.205 & pound avoirdupois (lb) \\
\hline
\end{tabular}

\section{Datum}

Horizontal coordinate information is referenced to the World Geodetic System of 1984 (WGS 1984).

\section{Abbreviations}

$\begin{array}{ll}\text { AEZ } & \text { agroecological zone } \\ \text { API } & \text { application program interface } \\ \text { ARD } & \text { analysis-ready data } \\ \text { AWS } & \text { Amazon Web Services } \\ \text { Bha } & \text { billion hectares } \\ \text { BWU } & \text { blue-water use } \\ \text { C1,C2, C3, C4, C5, C6 } & \text { composite time periods (of varying lengths) } \\ \text { ca. } & \text { circa } \\ \text { CGLS-LC100 } & \text { Copernicus global land service land cover } \\ \text { Commun. } & \text { communication } \\ \text { CORINE } & \text { Europe's Coordination of Information on the Environment Land Cover } \\ \text { COVID-19 } & \text { novel coronavirus, year 2019 } \\ \text { DEM } & \text { digital elevation model } \\ \text { EC } & \text { errors of commission } \\ \text { EO } & \text { errors of omission } \\ \text { ESA-S2-LC20 } & \text { European Space Agency Sentinel-2A land cover } \\ \text { ETM+ } & \text { Enhanced Thematic Mapper Plus } \\ \text { EVI } & \text { enhanced vegetation index } \\ \text { FAO } & \text { Food and Agricultural Organization [of the United Nations] } \\ \text { FA02013 } & \text { cropland areas from FA0 from 2013 } \\ \text { FA0-GLC } & \text { FAO global land-cover network }\end{array}$




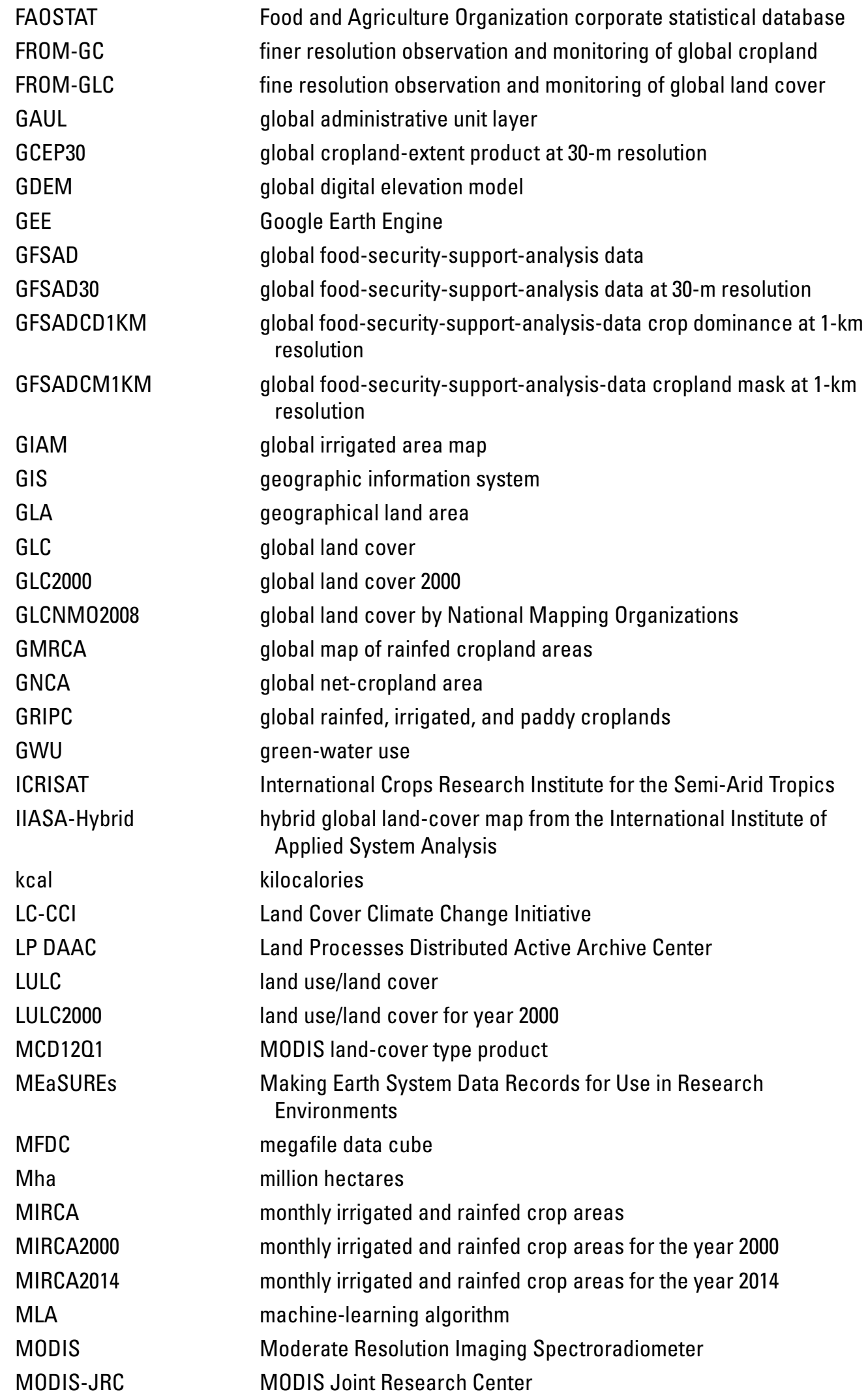




\begin{tabular}{|c|c|}
\hline MODISLC & MODIS land-cover product \\
\hline MVC & maximum- or medium-value composite \\
\hline $\mathrm{N}$ & number of samples \\
\hline $\mathrm{n} / \mathrm{a}$ & not applicable \\
\hline NASA & National Aeronautics and Space Administration \\
\hline NBR & normalized burn ratio \\
\hline NCA & net-cropland area \\
\hline NDVI & normalized difference vegetation index \\
\hline NDWI & normalized difference water index \\
\hline NEX & NASA Earth Exchange \\
\hline NGA & National Geospatial-intelligence Agency \\
\hline NIR & near-infrared \\
\hline no. & number \\
\hline OA & overall accuracy \\
\hline PA & producer's accuracy \\
\hline PC1 & principal component 1 \\
\hline PC2 & principal component 2 \\
\hline$R^{2}$ & $\begin{array}{l}\text { statistical measure in which proportion of variability in independent } \\
\text { variables is explained by dependent variable, such as in linear or } \\
\text { nonlinear regression models }\end{array}$ \\
\hline $\mathrm{RF}$ & random forest \\
\hline RHSEG & recursive hierarchical segmentation \\
\hline SAGE & Center for Sustainability and the Global Environment \\
\hline SD bands & standard deviation bands \\
\hline SD-NDVI & standard deviation of NDVI \\
\hline SI & item number \\
\hline SRTM & Shuttle Radar Topography Mission \\
\hline SVM & support-vector machine \\
\hline SWIR1 & short-wave infrared band 1 \\
\hline SWIR2 & short-wave infrared band 2 \\
\hline TGNCA & total global net-cropland area \\
\hline TIR & thermal infrared \\
\hline TNCA & total net-cropland area \\
\hline UA & user's accuracies \\
\hline UCL & unified cropland layer \\
\hline UN & United Nations \\
\hline USDA & U.S. Department of Agriculture \\
\hline USGS & U.S. Geological Survey \\
\hline USSR & Union of Soviet Socialist Republics \\
\hline VARI & visible atmospherically resistant index \\
\hline VHRI & very high resolution imagery \\
\hline
\end{tabular}





\title{
Global Cropland-Extent Product at 30-m Resolution (GCEP30) Derived from Landsat Satellite Time-Series Data for the Year 2015 Using Multiple Machine-Learning Algorithms on Google Earth Engine Cloud
}

\author{
By Prasad S. Thenkabail, ${ }^{1}$ Pardhasaradhi G. Teluguntla, ${ }^{1,2}$ Jun Xiong, ${ }^{1,2}$ Adam Oliphant, ${ }^{1}$ Russell G. Congalton, ${ }^{3}$ \\ Mutlu Ozdogan, ${ }^{4}$ Murali Krishna Gumma, ${ }^{5}$ James C. Tilton, ${ }^{6}$ Chandra Giri, ${ }^{7}$ Cristina Milesi, ${ }^{6}$ Aparna Phalke, ${ }^{4}$ \\ Richard Massey, ${ }^{8}$ Kamini Yadav, ${ }^{3}$ Temuulen Sankey, ${ }^{8}$ Ying Zhong, ${ }^{9}$ Itiya Aneece, ${ }^{1}$ and Daniel Foley ${ }^{1}$
}

\section{Executive Summary}

Global food and water security analysis and management require precise and accurate global cropland-extent maps. Existing maps have limitations, in that they are (1) mapped using coarse-resolution remote-sensing data of 250 meters (m) $(1$ pixel $=6.25$ hectares [ha]) to $10,000 \mathrm{~m}$ ( 1 pixel $=10,000$ ha $)$ resolutions, resulting in the lack of precise mapping location of croplands and their accuracies; (2) derived by collecting and collating national statistical data that are often subjective, leading to substantial uncertainties in cropland-area estimates, as well as their locations; and (3) extracted from one or more classes of a land use-land cover product in which cropland classes are not the focus of mapping, leading to their mixing with other classes and creating significant errors of omission and commission. These limitations can be overcome by producing high-resolution cropland-extent maps using satellite-sensor data, such as Landsat $30-\mathrm{m}$ ( 1 pixel $=0.09$ ha) resolution or higher. The most fundamental cropland product is the high-resolution cropland-extent map because all higher level cropland products, such as crop-watering method (that is, whether crops are irrigated or rainfed), crop types, cropping intensities, cropland fallows, crop productivity, and crop-water productivity, are all dependent on a precise and accurate cropland-extent product.

\footnotetext{
${ }^{1}$ U.S. Geological Survey.

${ }^{2}$ Bay Area Environmental Research Institute.

${ }^{3}$ University of New Hampshire.

${ }^{4}$ University of Wisconsin-Madison

${ }^{5}$ International Crops Research Institute for the Semi-Arid Tropics.

${ }^{6}$ National Aeronautics and Space Administration.

${ }^{7}$ U.S. Environmental Protection Agency.

${ }^{8}$ Northern Arizona University.

${ }^{9}$ Esri.
}

Given these realities, the overarching goal of this study was to produce a Landsat satellite-derived global cropland-extent product at 30-m resolution (GCEP30). The work, which involved a paradigm shift in how global cropland-extent maps are produced, involved the following five key steps: (1) petabyte-scale computing that involved multiyear, 8- to 16-day, time-series Landsat 30-m resolution data for the global land surface; (2) composition of analysis-ready data (ARD) cubes; (3) creation of a large global-reference data hub for machine learning; (4) use of multiple machine-learning algorithms (MLAs) by writing software and computing in the cloud; and (5) Google Earth Engine (GEE) cloud computing.

The five key steps involved nine distinct phases. First, the world was segmented into 74 agroecological zones (AEZs). Second, Landsat 8- to 16-day data were used to time-composite 10-band (blue, green, red, near-infrared [NIR], short-wave infrared band 1 [SWIR1], short-wave infrared band 2 [SWIR2], thermal infrared [TIR], enhanced vegetation index [EVI], normalized difference water index [NDWI], and normalized difference vegetation index [NDVI]) Landsat 30-m resolution data cubes for every 2- to 4-month time period during 3- to 4-year periods (stated as nominal-year 2015 or, simply, 2015), along with two additional 30-m resolution bands (Shuttle Radar Topography Mission [SRTM] elevation, slope) in each of the 74 AEZs. Third, more than 100,000 reference-training data samples were collected using ground data (some of which were collected using a mobile application), as well as submeter- to 5-m-resolution, very high-resolution imagery (VHRI) sourced from other reliable sources. Fourth, reference-training data were used to create a knowledge base for separating cropland from noncropland. Fifth, MLAs such as the pixel-based supervised random forest (RF) and support-vector machines (SVMs) were written on the GEE using Python and JavaScript. Sixth, object-based recursive hierarchical segmentation (RHSEG) algorithm was used, in addition to MLAs, to overcome uncertainties. Seventh, MLAs used the knowledge base to classify and separate cropland from noncropland. 
Eighth, accuracy assessment was conducted by generating error matrices for each of the 74 AEZs using 19,171 independent validation-data samples. Ninth, cropland areas were computed for all countries of the world and compared with United Nation's (UN's) Food and Agricultural Organization (FAO) and other national statistics.

The outcome was a Landsat-derived global cropland-extent product at 30-m resolution (GCEP30), ${ }^{10}$ which has an overall accuracy of 91.7 percent. For the cropland class, producer's accuracy was 83.4 percent, and user's accuracy was 78.3 percent. GCEP30 calculated (using direct pixel count) the global net-cropland area (GNCA) for the year 2015 as 1.873 billion hectares (Bha) ( 12.6 percent of the Earth's terrestrial area). The continental cropland distribution as a percentage of GNCA was Asia, 33 percent; Europe, 25.5 percent; Africa, 16.7 percent; North America, 14.4 percent; South America, 8.1 percent; and Australia and Oceania, 2.4 percent. The worldwide cropland areas in GCEP30 for 2015 were higher by 236 to 299 million hectares (Mha) compared to national statistics reported elsewhere for the same year (for example, in Food and Agriculture Organization's corporate statistical database [FAOSTAT] and in the monthly irrigated and rainfed crop areas [MIRCA] database). The global cropland area reported for 2015 increased by 344 Mha (22.5 percent), compared to the year 2000. During the same period (2000-2015), the world's population increased by 20 percent. Whereas some of these areal increases are real increases in cropland areas, others are due to the types of data, methods, and approaches used. Using the highest known resolution (compared to previous coarse-resolution global products) enabled this study to capture fragmented croplands. Coarse-resolution data compute areas on the basis of subpixels, which, for a large proportion of certain land use-land cover classes, will show only a certain percentage of the total pixel area as actual area. Subpixel areas can lead to substantial uncertainties in area computation, as determining the exact fraction of cropland areas within a coarseresolution pixel is resource intensive and subject to errors. Other innovations in GCEP30 include reference-data hubs, machine learning, and cloud computing. A comparison of the countrywise statistics on cropland areas reported in FAOSTAT, using GCEP30-derived cropland data, showed that GCEP30 explained the 93 percent variability in FAOSTAT countrywise cropland data. The slope of the predicting line was 0.89 .

Cropland areas in 214 countries, territories, departments, and regions were calculated for the year 2015 using GCEP30, on the basis of UN's global administrative unit layers (GAUL) boundaries (Food and Agricultural Organization of the United Nations [FAO], 2015). The 10 leading countries in terms of cropland area (as a percentage of the GNCA) were India (9.6 percent), United States (8.95 percent), China (8.82 percent), Russia (8.32 percent),

\footnotetext{
${ }^{10}$ The GCEP30 product, which can be browsed at full resolution at www. croplands.org, was released to the public through the joint U.S. Geological SurveyNational Aeronautics and Space Administration's Land Processes Distributed Active Archive Center (LP DAAC) (U.S. Geological Survey and National Aeronautics and Space Administration, 2017; see https://pdaac.usgs.gov/news/ release-of-gfsad-30-meter-cropland-extent-products/). A complete list of citations for the individual map products is provided in the section entitled, "Data."
}

Brazil (3.42 percent), Ukraine (2.32 percent), Canada (2.29 percent), Argentina (2.05 percent), Indonesia (2 percent), and Nigeria (1.91 percent). Together, these 10 countries occupy 50 percent of the global cropland, and they have 52 percent of the global population. Their combined cropland area increased by 2 percent between 2000 and 2015, compared to the substantial increase in population of 517 million (15.5 percent). Together, four countries (India, United States, China, and Russia) encompass 36 percent of the total area. In the United States and Canada, from 2000 to 2015, cropland decreased by about 2 percent, whereas their populations increased by 14 and 13 percent, respectively. The additional food requirements in these 10 countries, which are caused by increased populations, as well as increasing nutritional demands, are met by production increases in existing cropland or through virtual food trade, or both.

More than 18 countries, territories, departments, or regions had 60 percent or more of their geographic area as cropland: three countries (Republic of Moldova, San Marino, and Hungary) had more than 80 percent of the country's area as cropland; four countries (Denmark, Ukraine, Ireland, and Bangladesh), 70 to 80 percent; and 11 countries (Uruguay, Netherlands, United Kingdom, Spain, Lithuania, Poland, Gaza Strip, Czechia, Italy, India, and Azerbaijan), 60 to 70 percent. Europe and South Asia can be considered agricultural capitals of the world, on the basis of their percentages of geographic area as cropland. United States, China, and Russia, which all have high cropland areas, are ranked second, third, and fourth in the world; India is ranked first. However, the amount of cropland as a percentage of the country's geographic area is relatively very low for United States (18.3 percent), China (17.7 percent), and Russia (9.5 percent), whereas it is 60.5 percent for India. Most African and South American countries, territories, departments, or regions have less than 15 percent of their geographic area as cropland.

China and India together house 36 percent of the world's population; however, between 2000 and 2015, the amount of China's cropland area fell by 18.9 percent, owing to urban expansion and the abandonment of farmlands caused by demographic changes (that is, the movement of population from villages to cities). In contrast, China's population grew by 10 percent. The amount of India's cropland increased by 8.5 percent, whereas its population grew by 20 percent.

This study showed that, out of the 10 leading cropland countries, four countries (Ukraine, Nigeria, Russia, and Indonesia) showed an 18 to 31 percent increase in cropland areas, on the basis of GCEP30 by the year 2015, compared to 2000. Nigeria's cropland area increased by 25 percent, and its population increased by 31 percent in the same period. In these countries, food security is maintained by cropland expansion, productivity increases, and virtual food trade. Nevertheless, this trend of increasing net-cropland area and productivity will likely become difficult to maintain, owing to diminishing arable lands and plateauing of 50 years of continual yield increases, requiring policymakers to explore novel and data-supported approaches to solving future food security issues.

The GCEP30 product, which can be browsed at full resolution at www.croplands.org, has been released for public 
download and use through U.S. Geological Survey (USGS)National Aeronautics and Space Administration (NASA) Land Processes Distributed Active Archive Center (LP DAAC) (U.S. Geological Survey and National Aeronautics and Space Administration, 2017; see https://lpdaac.usgs.gov/news/ release-of-gfsad-30-meter-cropland-extent-products/).

\section{Introduction}

Accurate and precise global cropland-extent maps are crucial for understanding, modeling, mapping, and monitoring food and water security. As global population is expected to reach 11 to 12 billion by the year 2100 (Gerland and others, 2014; United Nations [UN], 2019), the demand for agricultural commodities such as food, fodder, and biofuels is expected to increase by 70 to 100 percent by 2050 (Tilman and others, 2011; Kastner and others, 2012; Food and Agricultural Organization of the United Nations [FAO], 2017) and possibly twice that percentage by 2100 (High Level Panel of Experts, 2020). Further, global average nutritional requirements are expected to increase from about 2,285 kilocalories (kcal) in 2010 to 2,538 kcal in 2100 (Depenbusch and Klasen, 2019). An increasing population together with growing calorie intake will mean that the world will need 80 percent more calories by the year 2100 to feed the global population (Depenbusch and Klasen, 2019). Theoretically, this demand can be met either through cropland expansion or cropland intensification. However, of the about 3 billion hectares (Bha) that are suitable for crop production (Molotoks and others, 2018), most estimates show that nearly half is already under cultivation (Thenkabail and others, 2011, 2012; Thenkabail, 2012; Teluguntla and others, 2015). Much of the rest is either in tropical forests or in other ecologically sensitive areas (Smith and others, 2010; Delzeit and others, 2017). Furthermore, nearly 90 percent of all global human water use goes towards producing food from agriculture (Hoekstra and Mekonnen, 2012; Dalin and Konar, 2019; Huang and others, 2019), of which nearly 70 percent is being used by $1.2 \mathrm{Bha}$ of rainfed cropland (that is, green-water use [GWU]) and the remaining 30 percent by 400 million hectares (Mha) of irrigated cropland (that is, blue-water use [BWU]) (Siebert and Döll, 2010; Thenkabail and others, 2010, 2016; Peña-Arancibia and others, 2014; Teluguntla and others, 2016; Huang and others, 2019). Global agricultural crop GWU and BWU will increase by 12 and 70 percent, respectively, by the 2090s, compared to the period between 1970 and 2000 (Huang and others, 2019). Hence, croplands are crucial for crop-water assessments, as well as to manage the world's water resources.

Many other situations arise in which global cropland-extent products are critical. For example, the recent spread of the novel coronavirus (COVID-19) threatens to globally derail supply chains, especially those for global food security. In a globally connected world in which food in supermarkets comes from every corner of the world, the threat of pandemics such as COVID-19 on global food security are real (International Food Policy Research Institute, 2020). The International Food Policy Research Institute's global model calculates that, for every global economic slowdown of 1 percent, the number of people living in poverty (and, with it, the number of food-insecure people) would increase by 2 percent, or by about 14 million persons worldwide (Vos and others, 2020). Against this background, a clear understanding of the global foodsupply chain requires high-resolution global cropland-extent maps that show information such as the location of croplands, their area, and their productivity modeling, mapping, and monitoring, as well as what crops are grown where.

Globalization requires globally coordinated land-use responses (Tramberend and others, 2019). Food-consumption patterns are inextricably linked to land-use and land-cover changes (Osei-Owusu and others, 2019). Cropland dynamics are changing in many ways. Migration from rural to urban areas is taking place rapidly in many parts of the world (for example, China, India, and Southeast Asia). These trends in demographic change are expected to result in nearly 85 percent of the world's population living in cities or towns by the year 2100 (UN, 2018), leading to farmlands either being abandoned or being managed using high-tech industrial farming by converting small, fragmented farms into larger farms. Crop types also are rapidly changing from traditional monocrops such as rice or wheat to more diverse cropping to meet the variety of food demanded by modern, globally connected consumer markets. In the coming decades, a substantial percentage of fertile farmlands will be lost to industrialization, urbanization, and salinization. Although food production can be increased through cropland expansion and intensification, the scope for sustainable expansion is limited owing to ecological and climatic concerns about converting forests and wetlands to cropland. Wu and others (2018) established that an opportunity exists for increasing global cropping intensity in existing cropland by 271 to 736 Mha, depending on various temperature- and precipitation-limiting factors. Adding cropland areas as a result of increasing cropping intensity will compensate for cropland areas lost owing to a wide variety of factors such as salinization, urbanization, industrialization, and rural migration to urban areas. However, sustainable water availability to grow more than one crop in a year in large areas is not yet assured because of the severe stresses on soils and also the need to maintain high levels of fertility, without having a fallow season to replenish nutrients. Global food demand also can be met by virtual land and water accounting. The total virtual land within global agricultural trade increased from 128 Mha in 1986 to 350 Mha in 2016, an average annual growth rate of 5.73 percent (Qiang and others, 2020). Global virtual water transfer constitutes 30 percent of direct freshwater withdrawal (Dalin and others, 2012; Wu and others, 2019), of which agriculture is a major component. As a result of globalization, nearly 35 percent of all food grown worldwide today (2021) is for export markets, a swift increase from about 16 percent in 1995 (Tramberend and others, 2019). This trend will increase in the coming decades, leading to greater global virtual land and water trade from agriculture.

In the past, during the Green Revolution era ( 19502010), the world's population rose from 2.5 billion to about 7 billion; during this time, the world's food security was mainly ensured through a combination of the following factors: (1) cropland expansion from about 300 to about 
1.6 Bha; (2) irrigation expansion from about 50 to about 400 Mha; (3) high-yield, fast-growing, short-duration crops provided by genetic engineering; (4) cropland intensification from single to double or triple cropping, in portions of about 400 Mha of irrigated cropland (and an almost negligible increase in rainfed cropland of about 1.2 Bha); (5) heavy application of supplements such as fertilizers and nitrogen; and (6) improvements in land management (for example, leveling, drainage) (Ramankutty and others, 2008; Pittman and others, 2010; Portmann and others, 2010; Thenkabail and others, 2010, 2011; Foley and others, 2011; Bodirsky and others, 2015; Niedertscheider and others, 2016).

\section{Current Needs}

In the future, farmland dynamics (expansion or contraction) in the 21st century are hard to predict owing to several emerging technologies that will have substantial effect on these changes both spatially and temporally. Ensuring food security for approximately 9.7 million people by the year 2050 and 11 to 12 billion people by the year 2100 will require a paradigm shift in how we use land and water to produce food (FAO, 2017). These measures may include the following:

1. Increased crop-water productivity (that is, more crop per unit of water allocation), as measured in kilograms per cubic meter $\left(\mathrm{kg} / \mathrm{m}^{3}\right)$ (Mekonnen and Hoekstra, 2014; Somkuti and others, 2020);

2. Improved cropland productivity (that is, more crop per unit of land area), as measured in kilograms per square meter $\left(\mathrm{kg} / \mathrm{m}^{2}\right)$ (Kayatz and others, 2019);

3. Adaptation to changing climate (Wassmann and others, 2019) through use of (a) climate-smart agriculture (Campbell and others, 2014; Makate, 2019), (b) extreme-weather agriculture (Gbegbelegbe and others, 2014; Johansson and others, 2015), and (c) drought-tolerant agriculture (Nuccio and others, 2018);

4. Advancement of urban and periurban agriculture (Badami and Ramankutty, 2015);

5. Avoidance of allocating fertile cropland areas to biofuel development or urbanization (Tripathi and others, 2016);

6. Production balance of food crops with that of dairy, meat, and fish (Forster and Radulovich, 2015);

7. Exploration of new sources of food (Forster and Radulovich, 2015);

8. Reduction of food waste (Corrado and Sala, 2018);

9. Creation of food banks during productive years (Wilkinson, 2015);

10. Maintenance of rich biodiversity (Sukara, 2014);
11. Development of plans for virtual cropland (Würtenberger and others, 2006) and virtual water use (Dalin and Konar, 2019; Duarte and others, 2019);

12. Precision smart farming (Relf-Eckstein and others, 2019);

13. Better crop management by means of accurate cropland mapping (Teluguntla and others, 2015, 2017a, 2018; Xiong and others, 2017a, b);

14. Use of geospatial technologies for improved planning (Thenkabail, 2015a, b, c);

15. Increase in global cropland-use intensity through better allocation of nitrogen, fertilizers, and irrigation (Odegard and van der Voet, 2014; Niedertscheider and others, 2016);

16. Increase in cropland-use intensity (Gumma and others, 2014, 2016);

17. Adaptation to low- or zero-carbon agriculture by measures such as increasing no-till cropland areas (Lal and others, 2004; Lal, 2014); and

18. Changes in diet (mainly, less beef production) (FAO, 2017).

This food-security challenge invariably calls for highly comprehensive global food (and water) security support-analysis data (GFSAD), which means that the dynamics of global agricultural land and water in the 21st century will be in a constant state of flux, requiring scientists and policymakers to understand, model, map, and monitor these changes rapidly, routinely, and accurately, year after year, both spatially and temporally. These food (and water) security challenges are most efficiently studied using remote-sensing methods and approaches (Becker-Reshef and others, 2010; Thenkabail, 2012, 2015a, b, c; Fritz and others, 2015).

Since the year 2000, we have seen several remote-sensingderived global cropland-extent maps that use satellite-sensor data (Bartholomé and Belward, 2005; Ramankutty and others, 2008; Thenkabail and others, 2009a; Biradar and others, 2009; BeckerReshef and others, 2010; Pittman and others, 2010; Portmann and others, 2010; Yu and others, 2013a, b, 2018; Teluguntla and others, 2015; Chen and others, 2015, 2017; Salmon and others, 2015; Fritz and others, 2015; Whitcraft and others, 2015a; Waldner and others, 2016; Liu and others, 2018). Cropland classes are in some of the global land use-land cover products (Giri and others, 2005; Herold and others, 2006, 2008; Bicheron and others, 2009; Friedl and others, 2010; Yu and others, 2013a, b; Zhu and Woodcock, 2014; Chen and others, 2015, 2017; Wang and others, 2015; Defourny and others, 2017; Xu and others, 2018; Gong and others, 2019); characteristics of, and years of production for, these croplands and land use-land cover products are provided in table 1. However, these products have significant limitations (Teluguntla and others, 2015; Whitcraft and others, 2015a; Waldner and others, 2016; Xu and others, 2019), leading to uncertainties in the precise locations of cropland areas and in the accuracies of the cropland-extent products and causing substantial errors in cropland areas derived from them. 
Table 1. State-of-the-art global cropland-extent mapping products, derived using satellite-image remote sensing.

[Abbreviations: ca., circa; FROM-GC, finer resolution observation and monitoring of global cropland; FROM-GLC, fine resolution observation and monitoring of global land cover; GFSADCD1KM, global food-security-support-analysis-data crop dominance at 1-km resolution; GFSADCM1KM, global food-security-support-analysis-data cropland mask at 1-km resolution; GIAM, global irrigated area map; GLC, global land cover; GLC2000, global land cover for year 2000; GMRCA, global map of rainfed cropland areas; GRIPC, global rainfed, irrigated, and paddy croplands; LULC, land use/land cover; m, meter; MCD12Q1, MODIS land-cover type product; MIRCA2000, monthly irrigated and rainfed crop areas for year 2000; MODIS, Moderate Resolution Imaging Spectroradiometer; MODIS-JRC, MODIS Joint Research Center; n/a, not applicable; no., number; SAGE, Center for Sustainability and the Global Environment; UCL, unified cropland layer]

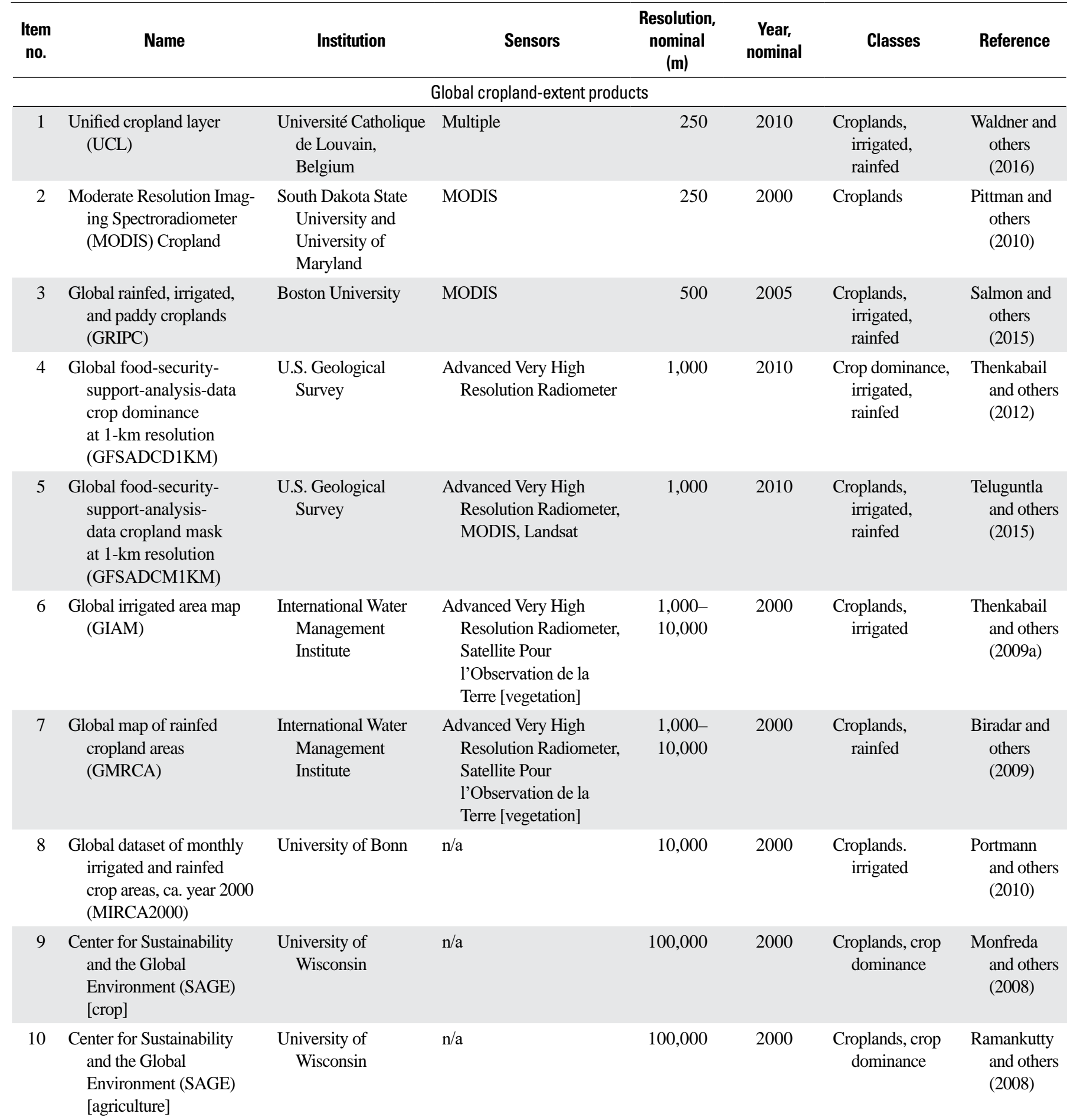


Table 1.-Continued

\begin{tabular}{|c|c|c|c|c|c|c|c|}
\hline $\begin{array}{l}\text { Item } \\
\text { no. }\end{array}$ & Name & Institution & Sensors & $\begin{array}{l}\text { Resolution, } \\
\text { nominal } \\
\text { (m) }\end{array}$ & $\begin{array}{c}\text { Year, } \\
\text { nominal }\end{array}$ & Classes & Reference \\
\hline \multicolumn{8}{|c|}{ Global land-use/land-cover products in which cropland classes exist } \\
\hline 11 & Globeland30 & $\begin{array}{l}\text { National Geomatics } \\
\text { Center of China }\end{array}$ & Landsat 7 & 30 & 2010 & LULC & $\begin{array}{c}\text { Chen and } \\
\text { others } \\
\text { (2015) }\end{array}$ \\
\hline 13 & $\begin{array}{l}\text { Finer resolution observation } \\
\text { and monitoring of global } \\
\text { land cover (FROM- } \\
\text { GLC) }\end{array}$ & $\begin{array}{l}\text { Center for Earth } \\
\text { System Science, } \\
\text { Tsinghua } \\
\text { University }\end{array}$ & Landsat 7 & 30 & ca. 2010 & LULC & $\begin{array}{l}\text { Gong and } \\
\text { others } \\
\text { (2013) }\end{array}$ \\
\hline 14 & $\begin{array}{l}\text { MODIS Joint Research } \\
\text { Center (MODIS-JRC) }\end{array}$ & $\begin{array}{l}\text { Joint Research } \\
\text { Center-Monitor- } \\
\text { ing Agricultural } \\
\text { Resources }\end{array}$ & MODIS, Landsat & 250 & 2009 & LULC & $\begin{array}{l}\text { Vancutsem } \\
\text { and others } \\
\text { (2013) }\end{array}$ \\
\hline 15 & Globcover & $\begin{array}{l}\text { European Space } \\
\text { Agency }\end{array}$ & $\begin{array}{l}\text { Medium-Spectral } \\
\text { Resolution, Imaging } \\
\text { Spectrometer }\end{array}$ & 300 & 2005, 2009 & LULC & $\begin{array}{l}\text { Defourny } \\
\text { and others } \\
\text { (2009) }\end{array}$ \\
\hline 16 & $\begin{array}{l}\text { MODIS land-cover type } \\
\text { product (MCD12Q1) }\end{array}$ & $\begin{array}{l}\text { National Aeronautics } \\
\text { and Space } \\
\text { Administration }\end{array}$ & MODIS & 500 & $\begin{array}{l}2004 \text { to } \\
\text { present } \\
\text { [2021] }\end{array}$ & LULC & $\begin{array}{l}\text { Leroux and } \\
\text { others } \\
\text { (2014) }\end{array}$ \\
\hline 17 & Global land cover (GLC) & Boston University & MODIS & 500 & $\mathrm{n} / \mathrm{a}$ & LULC & $\begin{array}{l}\text { Friedl and } \\
\text { others } \\
(2010)\end{array}$ \\
\hline 18 & DISCover & $\begin{array}{l}\text { U.S. Geological } \\
\text { Survey }\end{array}$ & $\begin{array}{l}\text { Advanced Very High } \\
\text { Resolution Radiometer }\end{array}$ & 1,000 & 1992-93 & LULC & $\begin{array}{l}\text { Loveland } \\
\text { and others } \\
\text { (2000) }\end{array}$ \\
\hline
\end{tabular}

The following are some limitations of existing global cropland-extent products:

Coarse spatial resolution.-Current global cropland-extent maps are 250 - to 10,000-meter (m) (6.25 to 10,000 hectares [ha] per pixel, respectively) spatial resolution, primarily relying on the Moderate Resolution Imaging Spectroradiometer (MODIS) satellite sensors. This low resolution has limitations at farm-level applications, especially when much of the world has individual farm sizes of less than a hectare;

Inadequate temporal and spectral resolutions.- Often, global cropland-extent products are created without having adequate temporal and (or) spectral resolution, which leads to substantial cloud-cover issues such as areas under permanently in cloud or haze cover in the limited number of images available for the area (Whitcraft and others, 2015b) and data of questionable quality. Limited spectral bands and lack of hyperspectral narrow bands limit product accuracy, especially when classifying multiple cropland classes;
Varying definitions. - All studies have different definitions of cropland. For example, some ignore cropland fallows in cropland maps, whereas others include rangelands with cropland;

Varying types of data.-Certain studies use a wide array of ancillary data (for example, elevation, soils), and others only use remote-sensing data. Some studies primarily use normalized difference vegetation index (NDVI) data, and others use data from multiple wavebands;

Varying methods.-Some products are created primarily using geospatial techniques, using national statistics and scaling them; others use a number of different pixel-based classifications; and yet some others use a combination of pixel- and object-oriented classification methods; and

Inadequate reference-training and data validation.Some global cropland-extent products suffer from inadequate reference-training and data validation owing to stiff resource constraints, as well as geopolitical constraints of obtaining data from all 195 countries of the world. 


\section{Existing Global Cropland-Extent Products}

Any one of the factors mentioned above, or combination thereof, could lead to a high degree of uncertainty in cropland-extent products-locally, regionally, and globally. Nabil and others (2020) showed that the overall accuracy of four remote-sensing-based cropland-extent products were less than 65 percent. Substantial differences are evident between different country-level statistics, available through the United Nations' (UN's) Food and Agriculture Organization (FAO) corporate statistical database (FAOSTAT; FAO, 2019b), or national statistics and global cropland-extent maps (Thenkabail and others, 2011; Teluguntla and others, 2015; Liu and others, 2018). Existing cropland-extent maps also disagree with one another, and they underestimate cropland areas relative to official statistics (Fritz and others, 2013). PérezHoyos and others (2017) compared FAO global land cover network (FAO-GLC), Geowiki (hybrid global land-cover map from the International Institute of Applied System Analysis), GLC2000 (Global Land Cover 2000), GLCNMO2008 (global land cover by National Mapping Organizations), GlobCover, Globeland30, LC-CCI (Land Cover Climate Change Initiative) 2010 and 2015, and MODISLC (MODIS land-cover product). The total cropland varied significantly among the most widely used global land-cover datasets, having generally very low full-agreement values from only 1.39 percent (North America) to 11.90 percent (Asia). Similar uncertainties were found in several other studies. For example, the overall accuracies of cropland classification varied between 61.26 and 80.63 percent (Chen and others, 2017) in four global land-cover datasets: MODIS land-cover product (Friedl and others, 2010); global land-cover map of 2009 (GlobCover2009; see Bicheron and others, 2009); finer resolution observation and monitoring of global cropland (FROM-GLC; see Yu and others, 2013a, b; Feng and others, 2014); and 30-m-resolution global land cover dataset (GlobeLand30; see Chen and others, 2015). Xu and others (2019) found great disagreement in spatial details of three land-cover products: the Copernicus global land service land cover (CGLS-LC100, 100-m resolution), European Space Agency Sentinel-2A land cover (ESA-S2-LC20, 20-m resolution), and finer resolution observation and monitoring of global land cover for Africa, version 2 (FROM-GLC-Africa30, 30-m resolution). Furthermore, varying methods and approaches cause their own uncertainties (Matton and others, 2015).

\section{Technical Advances in Global Cropland-Extent Product}

All these uncertainties call for a high-resolution (30-m resolution or better) cropland-extent map of the world. At $30 \mathrm{~m}$ (0.09 ha) per pixel, there are 11.11 data points per hectare, which is a quantum leap in how cropland is mapped relative to much coarser resolution studies that typically mapped cropland in $250-\mathrm{m}$ ( 1 pixel $=6.25 \mathrm{ha}$ ) to $10,000-\mathrm{m}$ (1 pixel $=10,000 \mathrm{ha}$ ) resolution. The need and importance of high-resolution, improved global cropland-extent data for food and water security is well documented (Kaptué Tchuenté and others, 2011; Fritz and others, 2013; See and others, 2015; Lark and others, 2017; Laso Bayas and others, 2017; Liu and others, 2018; Gong and others, 2019; Nabil and others, 2020). Until recently, mapping the world's cropland at 30-m-resolution was a great challenge and hard to bridge in terms of (1) managing and processing massive big data, (2) computational limitations, and (3) lack of adequate high-quality reference-training data that cover large areas to train algorithms and validate products. However, a paradigm shift and the following advances in remote-sensing science (Thenkabail and others, 2021) have made petabyte-scale global computing feasible in a quick timeframe:

Big data in the cloud.-Global computing at 30-m resolution requires petabyte-scale satellite-sensor big-data storage and presents data management issues, which are now addressed as a common service in the cloud. ${ }^{11}$ These cloud-based services eliminate the need to store massive datasets on local servers;

Analysis-ready data (ARD) cubes.-Multisensor data that are harmonized and synthesized (for example, geometrically, radiometrically, atmospherically corrected) and intersensor calibration are resulting in analysis-ready data (ARD) cubes in the cloud. The ARD cubes eliminate the time and resources required by users for data preparation and preprocessing. However, it must be noted that community standards for ARD are still evolving and are yet to happen at the global level. In this project, we created our own version of ARD (discussed later in the methods section);

Machine learning, deep learning, and artificial intelligence.These methods and tools can be applied on petabyte-size global or continental datasets, owing to parallel-computing available in the cloud;

Reference-training and -validation data.-The use of tools such as mobile applications to collect data from anywhere in the world that can instantly be transmitted to a server, the availability of very high, submeter- to 5-m-resolution imagery as reference, and the ability to acquire data from multiple sources (for example, crowdsourcing) all have enabled adequate reference-training data for machine learning and adequate validation data for assessing product accuracies, errors, and uncertainties;

\footnotetext{
${ }^{11}$ Cloud computing refers to the on-demand computing services available on the internet. These services include the storage of data; providing access to data; the ability to code and compute readily available algorithms for machine learning, deep learning, and artificial intelligence (ML-DL-AI); the ability to develop one's own ML-DL-AI algorithms and data by coding, using servers, and networking; and providing mechanisms to store one's data and share data and products. Cloud computing frees one from storing and managing data; rather, data are stored and managed elsewhere. Large clouds such as the Google Earth Engine (GEE) and Amazon Web Services (AWS) are managed in multiple centers throughout the world. An Application Programming Interface (API) helps users to connect with the cloud services and perform computing in the cloud platform. Strength of the cloud is data stability, professional management and protection, speed of computing, and ubiquitous accessibility. Satellite-sensor data such as those used in this study are massively large, petabyte-scale big data, which are harmonized, standardized, and managed in central locations in clouds such as GEE and AWS and are available anywhere in the world to anyone who has a internet connection and an authorized account.
} 
Cloud computing.-Cloud platforms such as Google's Google Earth Engine (GEE), Microsoft's Azure, and Amazon's Amazon Web Services (AWS) enable fast computing using the power of parallel computing;

Cloud-free data.-The availability of near-continuous, 8to 16-day satellite-sensor data such as Landsat and Sentinel in the cloud facilitates time compositing of multidate images; and

Software sharing.-Platforms for processing of imagery in the cloud have made the effort collective, coordinated, multiuser verified, seamless, and proficient.

The overarching goal, therefore, of this study was to develop a Landsat satellite-sensor-based global cropland-extent map product at 30-m resolution (GCEP30), which is the highest commonly available resolution, as well as to derive products for the nominal-year 2015 using machine-learning algorithms on GEE cloud-computing platform. This study used 8- to 16-day timeseries of Landsat 8 and Landsat 7 data for the 2013 through 2016 time period for the entire world. About 36,000 Sentinel images also were used in conjunction with the Landsat data for the African continent. For the rest of the world, only Landsat data were used. These several petabytes of data for the world were computed using multiple machine-learning algorithms (MLAs) such as the pixel-based supervised random forest (RF) and support-vector machines (SVMs) that use a knowledge base generated from reference-training data to separate cropland from noncropland. The world was divided into 74 agroecological zones (AEZs), and the data, methods, techniques, and approaches were analyzed separately for each zone to produce cropland-versus-noncropland products uniformly for the entire world. More than 100,000 reference-training data were used to train MLAs. A total of 19,171 reference-validation samples were used to assess accuracies, errors, and uncertainties in each AEZ. This global synthesis used the team's regional-continental synthesis that is based on the products published by the U.S. Geological Survey (USGS)-National Aeronautics and Space Administration (NASA) Land Processes Distributed Active Archive Center (LP DAAC) (U.S. Geological Survey and National Aeronautics and Space Administration [USGS and NASA], 2017; see https://lpdaac.usgs.gov/news/ release-of-gfsad-30-meter-cropland-extent-products/).

\section{Definitions of Cropland-Extent Mapping}

For the purpose of this study, net cropland extent mapped was defined as the sum of the following agricultural croplands (fig. 1):

- Cropland that is cultivated and harvested for food, feed, and (or) fiber, one or more times during a 12-month period;

- Cropland that is left fallow, even when equipped for agriculture; and

- Cropland that is permanently cropped with plantations (for example, orchards, vineyards, coffee, tea, and rubber).

Notably, pastureland is not part of the cropland, except for alfalfa in the United States and some other countries.
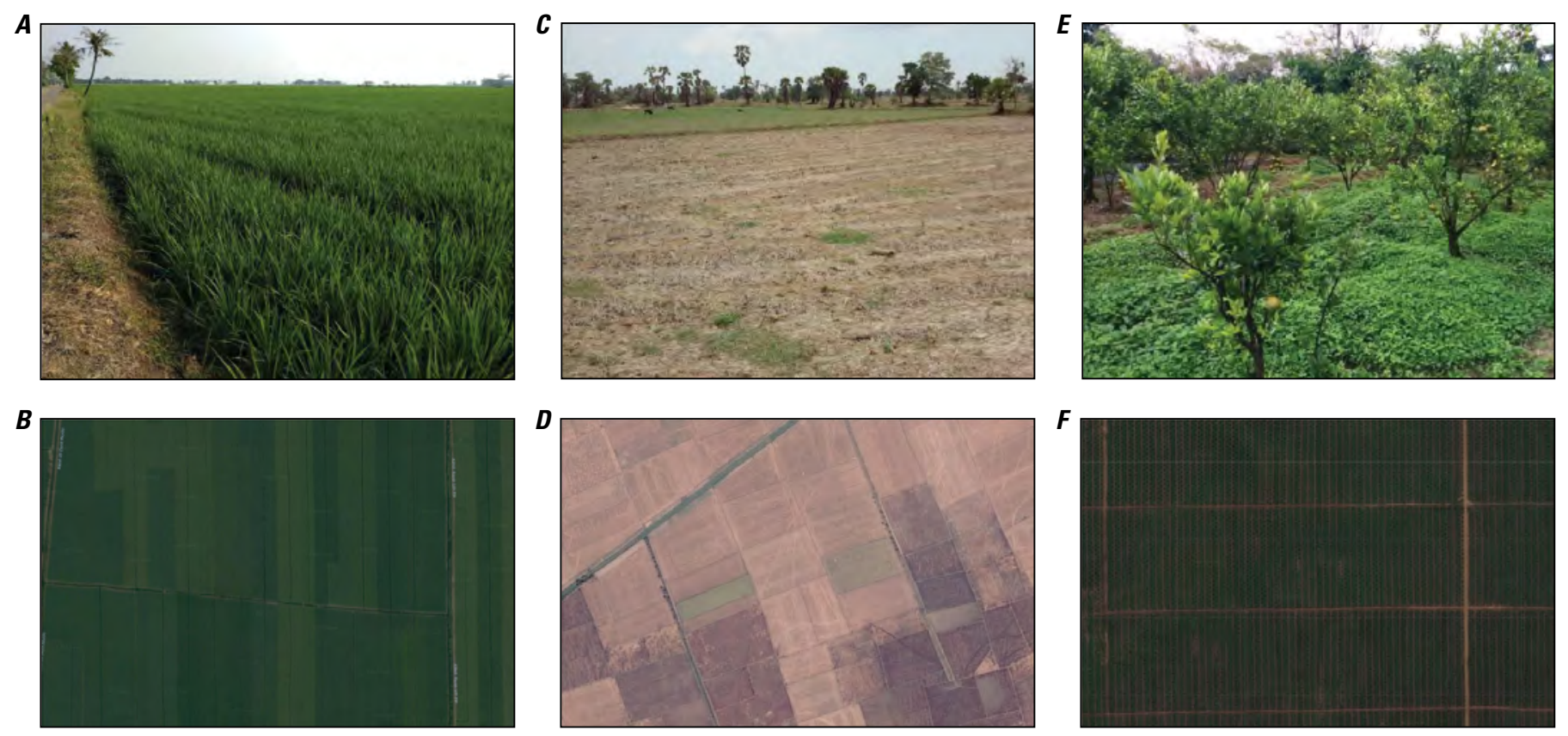

Figure 1. Photographs and Google Earth imagery showing examples of land covers in Uttar Pradesh, India, which are represented as agricultural cropland in cropland land-cover class, in global cropland-extent product at 30-m resolution (GCEP30) for nominal-year 2015. Photographs taken by Murali Krishna Gumma, International Crops Research Institute for the Semi-Arid Tropics (ICRISAT), August 2015. Google Earth images used with permission. $A$, Photograph of cropland. B, Google Earth image of same area as $A$, dated August 2015. $C$, Photograph of cropland fallows. D, Google Earth image of same area as $C$, dated November 2015. E, Photograph of plantation. $F$, Google Earth image of same area as $E$, dated August 2015. 
This definition was applied consistently for mapping GCEP30, using Landsat data for the nominal-year 2015. The study provides the following:

- Global cropland-extent ${ }^{12}$ product (GCEP30); and

- Global net-cropland areas (GNCAs), derived from the GCEP30.

When cropland (represented by a pixel) was planted and harvested at least once in a 12-month period, then that pixel is counted as GNCA (note that this study did not account for cropping intensity [that is, if the same cropland area was planted and harvested more than once in a year], as this was beyond the scope of this study). When land was equipped for cropping but not cropped anytime during a 12-month period, it was considered as cropland fallows and was counted as GNCA. A wide array of plantations or permanent crops (that is, those that remain cropped throughout a 12-month period) were also considered as GNCAs.

Defining mapping is crucial to understanding what is mapped, as well as for comparisons with other cropland-extent maps, in order to avoid differences across cropland-extent maps and the areas derived from them. For example, some cropland-extent maps include standing crops and not cropland fallows, whereas some include only annual crops and not plantations, and some include rangeland and grassland. In this study rangeland, grassland, and pastureland were not classified as cropland.

The Landsat-derived GCEP30 produced in this study and the GNCAs derived from it will follow a clear definition as shown in figure 1.

\section{Data}

This section discusses the global Landsat 8 and Landsat 7 time-series 30-m-resolution data, followed by reference-training and -validation data used to produce global cropland-extent products.

\section{Agroecological Zones}

Mapping cropland extent across the globe is a significant undertaking, owing to the enormous diversity in agriculture across the globe. Precipitation and temperature vary widely across the globe, as some continental regions have a short, narrow growing season, and other, more tropical regions have a warm and moist climate that is suitable for growing crops all year. This climatic diversity is an immense asset in ensuring food security because unmet fulfillment of the demand for food caused by crop failure often is a localized phenomenon and usually can be offset by surplus food grown in unaffected areas. Additionally, global-transportation and -trade agreements enable fresh produce to be available throughout the year. Crop types and farming practices also can vary widely;

\footnotetext{
${ }^{12}$ Cropland extent is the spatial distribution of cropland areas.
}

for example, a rice paddy in one area may appear as a flooded wetland in another. Owing to such diversity, applying the same model across the globe would be problematic.

To account for such differences, and also to divide the workload responsibility, the globe was divided into 13 regions, and each was mapped by remote-sensing specialists who have expertise in their particular region. The 13 regions are 1, Australia and New Zealand; 2, China; 3, Southeast Asia, which includes Korea, Japan, and island nations in the Pacific Ocean; 4, South Asia, which includes Afghanistan and Himalayan countries; 5, Africa, which includes island nations near the African continent; 6, Europe; 7, Central Asia and Russia; 8, Middle East; 9, South America; 10, North America; 11, Central America and the Caribbean; 12, Alaska and Iceland; and 13, Mongolia.

These 13 regions were further divided into subregions (fig. 2), on the basis of UN FAO's AEZs (Fischer and others, 2000). To aid in cropland classification, the AEZs, which are based on growing-degree days, soils, and terrain and elevation data, were adjusted slightly to align with political boundaries, as well as to keep them compact (and to minimize boundaries between AEZs). In total, $74 \mathrm{AEZs} \mathrm{were} \mathrm{created} \mathrm{for} \mathrm{the} \mathrm{world}$ (fig. 2); each AEZ had separate input imagery, training data, and accuracy assessment, as will be discussed in depth in the sections that follow.

Products for the 13 regions have been merged into the following seven subproducts, which can be downloaded from the LP DAAC (https://lpdaac.usgs.gov/news/ release-of-gfsad-30-meter-cropland-extent-products/):

- Africa (Xiong and others, 2017a)

- Australia, New Zealand, China, and Mongolia (Teluguntla and others, 2017a)

- Europe, Middle East, Russia, and Central Asia (Phalke and others, 2017)

- North America (Massey and others, 2017a)

- South America (Zhong and others, 2017)

- Southeast and Northeast Asia (Oliphant and others, 2017)

- Southern Asia, Afghanistan, and Iran (Gumma and others, 2017)

\section{Landsat 30-m-Resolution Time-Series Data- Establishing Analysis-Ready Data (ARD) Cubes}

Landsat 8 and Landsat 7 time series of 30-m-resolution, atmospherically corrected surface-reflectance data were seamlessly organized for the entire terrestrial area of the world on GEE cloud platform. Every 8-day image of the globe for between 2 and 6 years (for example, 2013-15) from Landsat 8 and Landsat 7 satellites (table 2) were organized as ARD cubes (fig. 3) for each of the 74 AEZs (fig. 2) on GEE. The ARD cubes consist of at least 


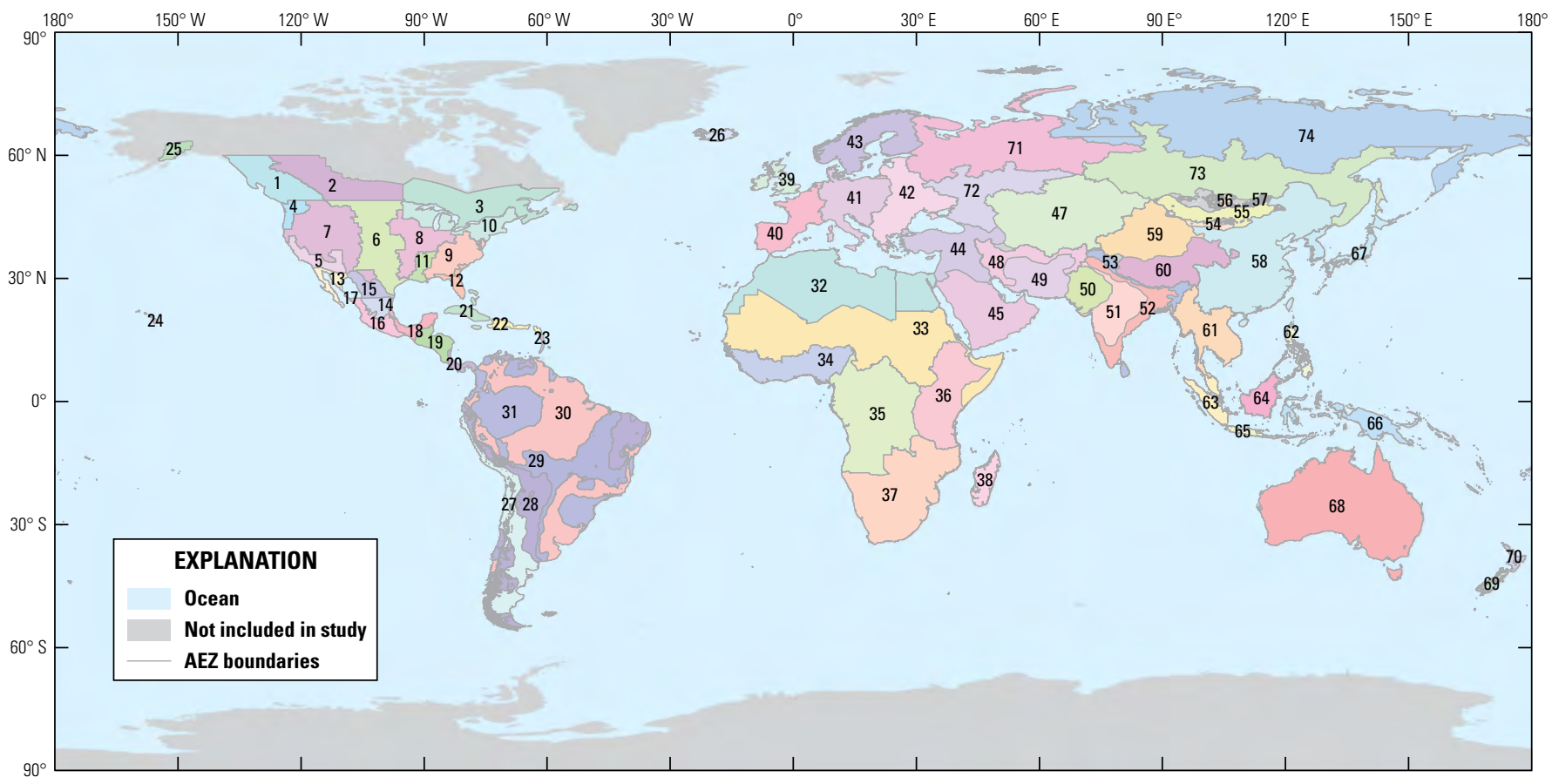

Figure 2. Map showing agroecological zones (AEZs) used in this study. AEZs are modified from global AEZs of Food and Agricultural Organization of the United Nations and the International Institute of Applied System Analysis (2012) on the basis of global digital elevation model (GDEM) (National Aeronautics and Space Administration and others, 2019) and also considering climate and agricultural patterns (FA0, 2019a).
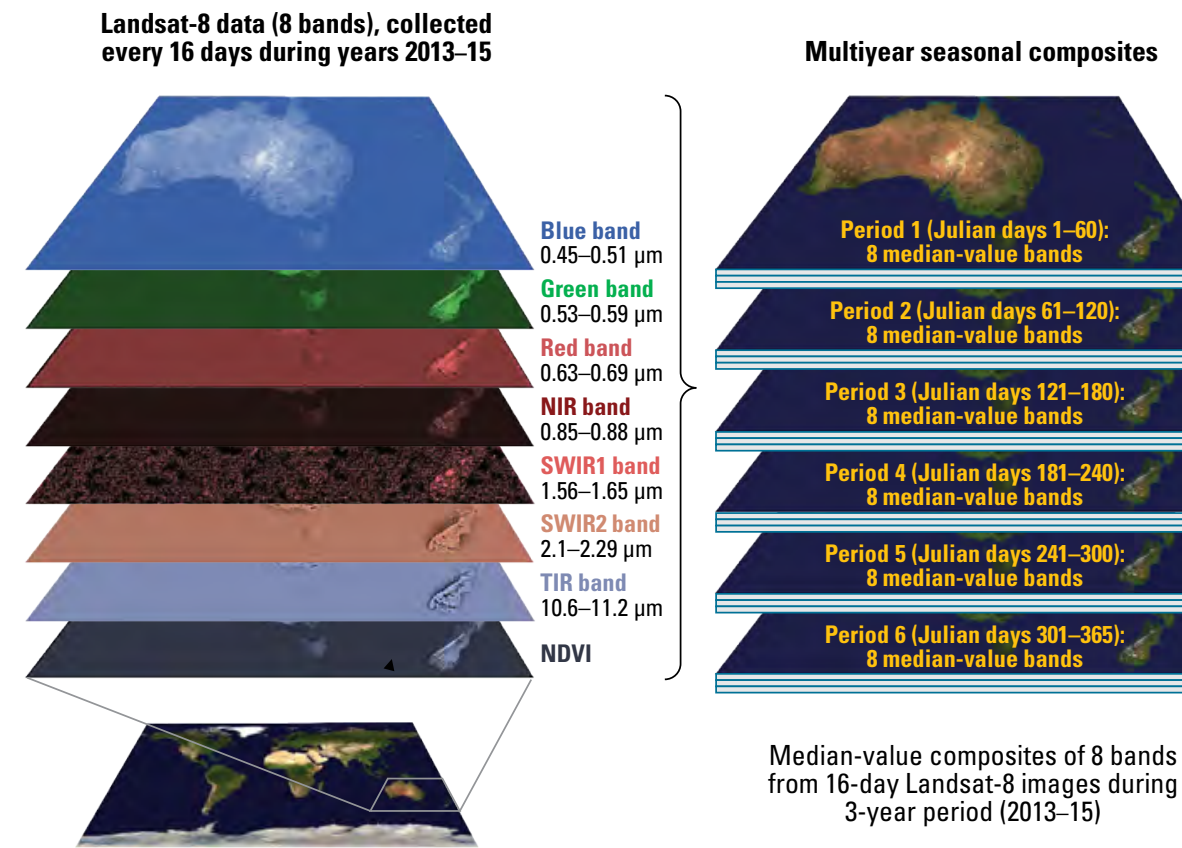

Figure 3. Diagram illustrating how Landsat 30-m resolution megafile data cube (MFDC) is compiled; example is from region of Australia and New Zealand. In this example, total of eight Landsat-8 bands (blue, green, red, near-infrared [NIR], short-wave infrared band 1 [SWIR1], short-wave infrared band 2 [SWIR2], thermal infrared [TIR], and normalized difference vegetation index [NDVI]) for each 16-day interval were used for three years (2013-15). Each band was temporally composited for six time periods, each of which was for two-month interval during three-year period (2013-15): for period 1 (Julian days 1-60), all eight bands were composited, taking for each band a maximum- or medium-value composite of all images available; this process was repeated for other time periods, resulting in total of 48 bands. To this were added Shuttle Radar Topography Mission (SRTM) elevation and slope bands, resulting in 50-band MFDC. Other abbreviations: $\mathrm{m}$, meter; $\mu \mathrm{m}$, micrometer. 
Table 2. Landsat 30-m-resolution analysis-ready data (ARD) cubes composed for different regions of the world.

[Bands: EVI, enhanced vegetation index; NDVI, normalized difference vegetation index; NDWI, normalized difference water index; NIR, near-infrared; SD bands, standard-deviation bands; SWIR1, short-wave infrared band 1; SWIR2, short-wave infrared band 2; TIR, thermal infrared. Other abbreviations: ARD, analysis-ready data; $\mathrm{C1}$, C2, C3, C4, C5, C6, composite time periods of varying lengths [see footnote below]; m, meter; MFDC, megafile data cube (total no. of bands in MFDC for China is 32 [8 bands, composited for 4 time periods, C1-C4]); NBR, normalized burn ratio; no., number; SD-NDVI, standard deviation of NDVI; VARI, visible atmospherically resistant index. Data used in cropland versus noncropland classifications in Google Earth Engine cloud using machine-learning algorithms. Landsat 30-m-resolution 16-day time-series data were composited over 2- to 6-month time periods (for example, January-February or January-February-March, or January-February-March-April; and similarly for May-June, May-June-July, and so forth) and during 2 to 5 years (for example, 2013-16 means that 2- to 6-month time periods were composited over four years) by obtaining their maximum-value composites during that time period for each of 10 bands (blue, green , red, NIR, SWIR1, SWIR2, TIR, EVI, NDWI, NDVI), which resulted in 12- to 68-band ARD cubes for different study areas of world]



${ }^{1} \mathrm{C}$, composite number for time period (for example, $\mathrm{C} 1$ = composite 1); C1, 1-60 = composite 1, Julian days 1 to 60 (given that Landsat 8 is acquired during every 16 days, there will be four images in first 60 days); then each band (for example, blue) is derived using maximum value from these four images. 
seven Landsat bands (blue, green, red, NIR, ${ }^{13}$ SWIR1, $1{ }^{14}$ SWIR2,,${ }^{15}$ and $\mathrm{TIR}^{16}$ ), three vegetation indices (EVI, ${ }^{17} \mathrm{NDWI},{ }^{18}$ and $\mathrm{NDVI}^{19}$ ), and sometimes additional bands such as $\mathrm{SRTM}^{20}$-derived elevation and slope data (table 2; figs. 2, 3). For example, for the AEZs in Australia and New Zealand (fig. 3), the 10-band data (blue, green, red, NIR, SWIR1, SWIR2, TIR, EVI, NDWI, and NDVI) were temporally composited to get maximum- or median-value composites (MVCs) during three to six time periods per year. Each year was divided into six time periods (January-February, March-April, May-June, July-August, September-October, and November-December), each time period lasting about 60 days. During each 60-day period, eight Landsat images (from Landsat 8 and Landsat 7) are produced, each having 10 bands (blue, green, red, NIR, SWIR1, SWIR2, TIR, EVI, NDWI, and NDVI). Each band is temporally composited over the 60-day time period, using seven or eight Landsat images, to arrive at 10-band MVCs (fig. 3). The same process is repeated for all six time periods (fig. 3) to get a total of 60 MVC bands for the year. In addition, SRTM elevation and slope bands were added to AEZs 68, 69, and 70 (Australia and New Zealand; fig. 3), for a total of 62 bands. The same process was adopted for all 74 AEZs (fig. 2) to derive ARD cubes (fig. 3) by different groups within the team (table 2). Thus, the number of bands composited varied in different AEZs, depending on which region or continent they are located in (table 2).

Table 2 shows that data were composited sometimes for two years and sometimes for five. The choice of the number of years studied varied by continent to accommodate for reference-training data availability. Similarly, sometimes the time periods of composition varied from two to six years, in order to accommodate cloud-cover issues. Africa, for example, had only two time periods (1-180 days and 181-365 days), whereas Australia and New Zealand had six time periods. Ideally, the longer the time period, the greater the phenology variations within a year (or a 12-month period). However, when cloud cover is heavy or coverage of images is less frequent, a longer time period is preferred to ensure cloud-free, or nearly cloud-free, wall-to-wall coverage of entire regions or continents. Further, processing, which involves writing application program interface (API) scripts in Python or JavaScript in GEE for cloud-smoothing, takes temporal images and fills in data for cloud-, haze-, or noise-affected pixels. Generic scripts written to smooth cloud-, haze-, or noise-affected pixels using "peak counting" APIs (Xiong and others, 2017a, c; Teluguntla and others, 2018; Oliphant and others, 2019) were found to

\footnotetext{
${ }^{13} \mathrm{NIR}=$ near-infrared.

${ }^{14}$ SWIR1 $=$ short-wave infrared band 1.

${ }^{15}$ SWIR2 $=$ short-wave infrared band 2.

${ }^{16} \mathrm{TIR}=$ thermal infrared.

${ }^{17} \mathrm{EVI}=$ enhanced vegetation index.

${ }^{18} \mathrm{NDWI}=$ normalized difference water index.

${ }^{19} \mathrm{NVDI}=$ normalized difference vegetation index.

${ }^{20}$ SRTM = Shuttle Radar Topography Mission.
}

be superior to the widely used $\mathrm{F}_{\text {mask }}^{21}$ script (Zhu and others, 2015; Qiu and others, 2017). The "peak counting” involves filling in data missing in an image as a result of cloud cover by taking spectral reflectivity or NDVI data of temporal images before and after the image that had the cloud-cover issue (see Xiong and others, 2017c). The ultimate goal was to produce temporally composited images during time periods to achieve cloud-free, or nearly cloud-free, images through APIs.

Our assessments showed that, in all 74 AEZs (fig. 2), the ARD cubes (fig. 3; table 2) were cloud free, or nearly cloud free, as a result of the intelligent processing chain developed in this project by taking advantage of two Landsat satellites (Landsat 8 and Landsat 7), by time-compositing over time periods, as well as by writing APIs to eliminate noisy or cloudy pixels. Using these measures, cloud cover in the ARD cubes (fig. 3) was invariably always less than 1 percent of the total area of the AEZs (fig. 2) and, hence, negligible. This was possible by taking a large number of time-series images that were temporally composited over adequate time periods and then using cloud-smoothing "peanb/k counting" algorithms (Xiong and others, 2017c) to overcome any cloud-cover issues that still exist after developing MVCs, resulting in ARD.

The ARD data, in summary, had the following characteristic processes: (1) time-series 10-band (blue, green, red, NIR, SWIR1, SWIR2, TIR, EVI, NDWI, and NDVI) Landsat 8 and Landsat 7 data for a chosen two- to five-year period (table 2); (2) time-compositing Landsat 8 and Landsat 7 images over two to six time periods in a 12-month period; (3) developing MVC data cubes (fig. 3) for each of 74 AEZs (fig. 2); (4) using atmospherically corrected surface-reflectance Landsat 8 and Landsat 7 data; and (5) applying "peak counting" algorithms to overcome cloud, haze, and noise effects. The final 23- to 68-band (table 2) data cube formed the ARD for further analysis of global cropland extent.

\section{Reference-Training and -Validation Data}

High-quality reference-training and -validation data are crucial for a highly accurate and low-uncertainty cropland-extent product. These reference-data samples must be spatially well distributed, must avoid autocorrelation, and must be of sufficient sample size (Congalton and others, 2014). The project involved a detailed design and implementation of reference training and validation obtained from multiple sources. More than 120,000 sample locations (fig. 4) were collected from one of the following three main sources:

1. Very high resolution imagery (VHRI)-derived reference data.-VHRI (at submeter to 5-m resolution) were available from the National Geospatial-Intelligence Agency (NGA). Interpretation of these more than 45,000 sample locations (fig. 4) for the world led to their categorization as either cropland or noncropland. The

\footnotetext{
${ }^{21}$ The $\mathrm{F}_{\text {mask }}$ script is used to identify cloud-contaminated pixels; however, it often has significant uncertainties in removing the driest pixels.
} 
process of VHRI-derived sample-location collection involved the following steps:

- More than 250,000 sample locations were randomly distributed across the world. Note that many of these sample locations may not have had VHRI; such sample locations were dropped;

- A trained interpreter zoomed in to each sample location using VHRI and visually interpreted whether the location was a cropland or noncropland within a $90 \times 90-\mathrm{m}$ area. This process also involved dropping uncertain or impure sample locations (for example, edge pixels, pixels that had cloud or haze issues, and pixels about which the interpreter was not fully certain [that is, interpreter uncertainty]);

- A second interpreter independently interpreted the sample locations; and

- A third interpreter retained only the sample locations that had been interpreted similarly by the two interpreters; sample locations that had a mismatch in interpretations were dropped.

2. Ground-reference data.-These consisted of more than 14,000 sample locations (fig. 4) across the world. A substantial proportion of ground-reference-data samples were collected by our team members (Teluguntla and others, 2018; Gumma and others, 2019; Oliphant and others, 2019), with or without using our ground-data application, Global Croplands Mobile Application (available at https://croplands.org/mobile). Each sample location had the following:

- Coordinates;

- Date of collection;

- Interpretation as either cropland or noncropland;

- Crop type(s); and

- Interpretation as either irrigated, rainfed, or supplemental irrigation.

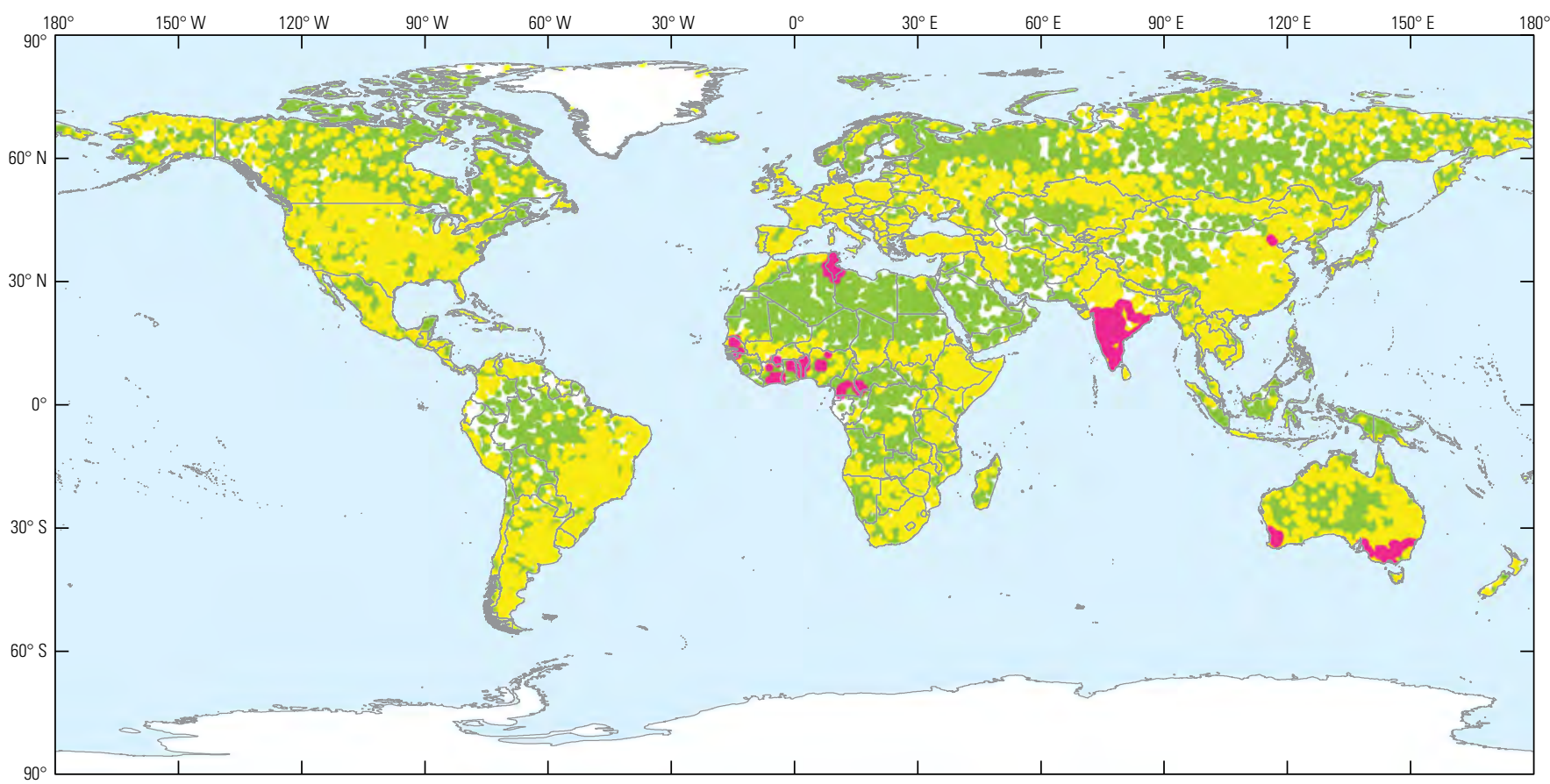

EXPLANATION

Data localities

- Ground-data and mobile-application reference-training and -validation data $(N=>14,000)$

- Secondary reference-training and -validation data $(N=>41,000)$

- Very high resolution reference-training and -validation data $(\mathrm{N}=>45,000)$

Country boundary

Figure 4. Map showing locations of about 120,000 reference-training and -validation data samples used for machine-learning algorithms and cropland-extent-product validation. About 120,000 original data samples of ground data, which were sourced from various campaigns, were collected using our mobile application (see https://www.croplands.org/mobile), in addition to data from very high resolution imagery (VHRI) gathered at submeter- to 5- $\mathrm{m}$ resolution from satellite-sensor data (IKONOS, Quickbird, and GeoEye). Of these 120,000 samples, about 100,000 were used for training machine-learning algorithms, and 19,171 samples (locations not shown here) were used for accuracy assessments. Abbreviation: $\mathrm{N}$, number of data samples. Country boundaries from Food and Agricultural Organization of the United Nations (2015). 
3. Secondary data.-Secondary data, which were acquired from a wide variety of highly reliable sources in a few countries or regions, are data that were either available publicly or were shared by our partners. The data were sourced from cropland data layers from (a) U.S. Department of Agriculture (USDA) (available at https:// www.nass.usda.gov/Research_and_Science/Cropland/ Release/) (Han and others, 2012; Vancutsem and others, 2013; Lark and others, 2017); (b) Agriculture and Agri-Food Canada (available at http://www.agr.gc.ca/ atlas/aci/); and (c) CORINE ${ }^{22}$ (available at https://land. copernicus.eu/pan-european/corine-land-cover) (Fritz, 2017). Furthermore, our partnerships with CGIAR (https://www.cgiar.org/) and the International Crops Research Institute for the Semi-Arid Tropics (ICRISAT; https://www.icrisat.org/) centers yielded significant ground data for many countries in Africa, Southeast Asia, and South Asia. Overall, more than 53,000 samples (fig. 4) of secondary data were collected for various parts of the world.

Out of approximately 120,000 samples, more than 100,000 training samples that were web enabled, searchable, and downloadable (https://croplands.org/app/data/search) were used for training MLAs. An additional 19,171 samples (independent of the training data samples) were used for validation of cropland-extent products (Congalton and others, 2017; Yadav and Congalton, 2018, 2019). In addition to the 19,171 validation samples, as many additional samples as necessary were developed for each region or continent (table 2) for class identification and labeling using VHRI to ensure that cropland is best identified and, thus, separated from noncropland.

\section{Methods}

We adopted a set of novel methods and approaches (fig. 5) in this complex project that involved the following:

- Multisensor time-series Landsat 8 and Landsat 7 seamless big-data integration in the cloud.-We acquired Landsat 8 and Landsat 7 time-series big data for multiple years (see section above entitled, "Landsat 30-m-Resolution Time-Series DataEstablishing Analysis-Ready Data (ARD) Cubes"; see also, table 2). We then harmonized and standardized the data by using radiometric and geometric corrections, top-of-the-atmosphere reflectance, atmospheric-corrected surface reflectance, and cloud, haze, and noise removal. The final data are in surface-reflectance time-series product seamlessly stitched for the entire world in the GEE cloud. Many processes already had been performed by the GEE team (Gorelick and others, 2017); the remaining

\footnotetext{
${ }^{22} \mathrm{CORINE}=$ Europe's Coordination of Information on the Environment Land Cover.
}

were performed by our team (Xiong and others, 2017c; Massey, 2017; Massey and others, 2017a, b, 2018; Teluguntla and others, 2018; Oliphant and others, 2019; Gumma and others, 2019). Our team wrote software for the data for the years of interest (table 2) and processed them for cloud removal (see section above entitled, "Landsat 30-m-Resolution Time-Series Data—Establishing Analysis-Ready Data (ARD) Cubes"), resulting in ARD cubes (fig. 2).

- Agroecological zone (AEZ) segments of the world.-We divided the world into 74 AEZs for the study (fig. 2), refining them for local climate and soil conditions on the basis of their original global agroecological zones (Food and Agricultural Organization of the United Nations and the International Institute of Applied System Analysis, 2012).

- Analysis-ready data (ARD) cubes. - In each of the 74 AEZs (fig. 2), we composed ARD (fig. 3) of Landsat imagery (Egorov and others, 2019; Zhu, 2019; Potapov and others, 2020) and other data for further processing.

- Machine-learning reference-training and -validation data hub for global agriculture.-Overall, we gathered more than 120,000 reference-training and -validation data (https://croplands.org/app/data/ search), of which more than 100,000 samples were used as reference-training data for machine learning and 19,171 reference data were used for validation of the products (Congalton and others, 2017). We distributed these samples, without autocorrelation, across the 74 AEZs.

- Knowledge-based generation for MLAs.-Using reference data on the ARD cubes, we generated a knowledge base (see, for example, fig. 6) to train MLAs (Xiong and others, 2017c; Teluguntla and others, 2018; Oliphant and others, 2019).

- MLAs and deep-learning algorithms.-We selected appropriate MLAs and deep-learning algorithms (see section below, entitled "Knowledge-Based Generation," for details) and used the knowledge base to classify ARD cubes.

- Cloud computing on GEE.-We wrote software and computed MLAs on the GEE cloud (Gorelick and others, 2017) to classify and discern cropland from noncropland.

- Accuracy error matrices. -We assessed accuracies using error matrices that produced overall accuracies, producer's accuracies (or errors of omissions), and user's accuracies (or errors of commission) (Olofsson and others, 2014; Congalton and others, 2014, 2017; Yadav and Congalton, 2018, 2019; Yadav, 2019). 

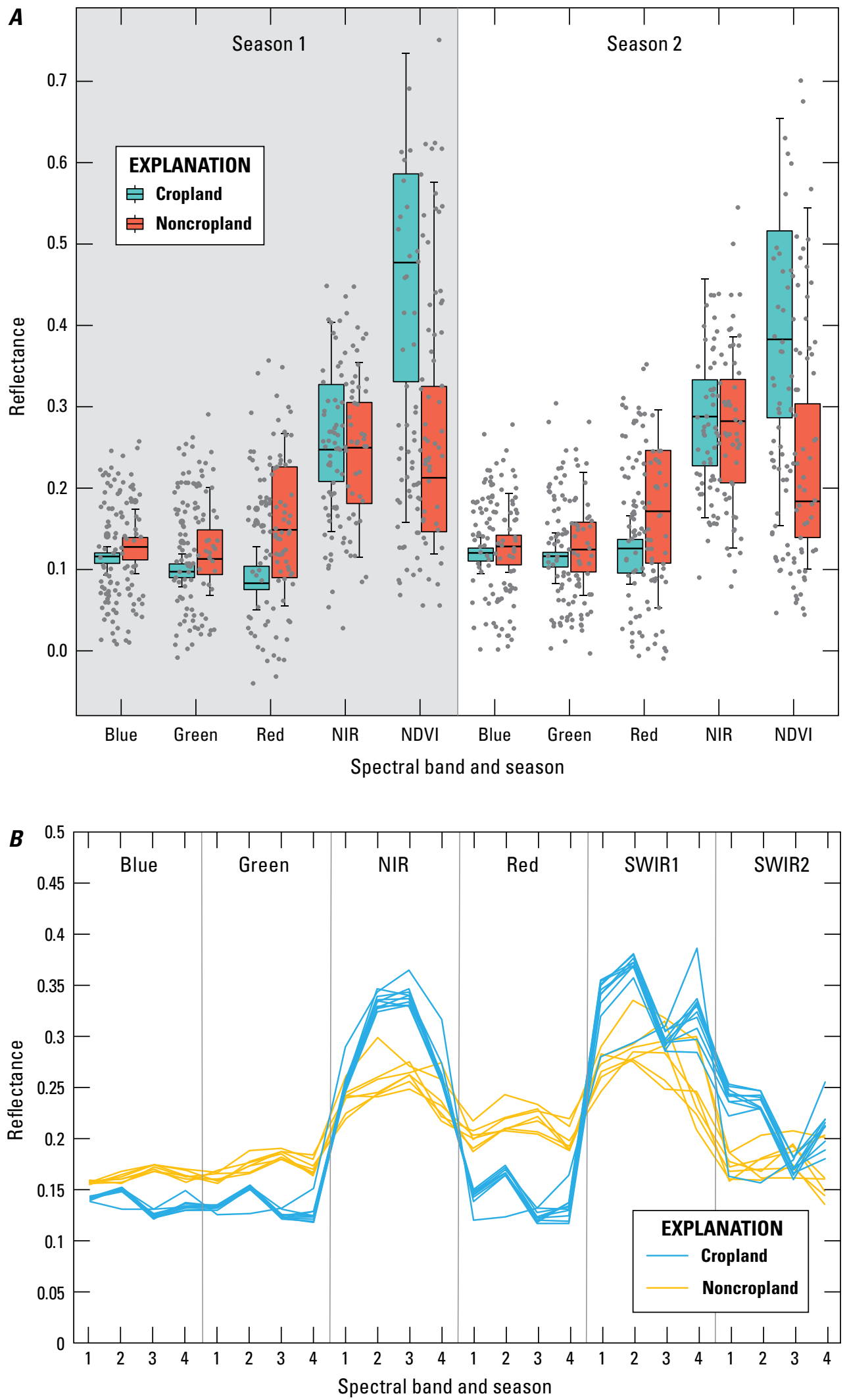

Figure 5. Two examples that show how primary spectral-reflectance data can be used to separate croplands from noncroplands. $A$, Plots of spectral-reflectance data (black dots) in blue, green, red, near-infrared (NIR), and normalized difference vegetation index (NDVI) spectral bands, which are used to separate cropland (red) from noncropland (green) across two crop-growing seasons (seasons 1, 2) in selected areas in Africa. Top and bottom of each box shows 75th- and 25th-percentile values, respectively, and middle shows mean value; error bars show 95th-percentile values. Negative values result from sensor noise or overcorrection in atmospheric-correction algorithms and can be ignored. Each of five spectral bands shows different levels of separability of cropland from noncropland in each season; using multiple bands from multiple seasons offers greater opportunity for separability of cropland from noncropland. This knowledge can be encoded to train machine-learning algorithms (MLAs) used to classify and separate croplands from noncroplands. $B$, Graph showing profiles of spectral-reflectance timeseries signatures of cropland (blue lines) and noncropland (gold lines), as obtained from different spectral bands (blue, green, near-infrared [NIR], red, and short-wave infrared bands 1 [SWIR1] and 2 [SWIR2]). Each spectral band is shown across the same four seasons $(1,2,3,4)$ in the same calendar year. 



Figure 6. Two examples that show how transformations of spectral-reflectance data can be used to separate croplands from noncroplands. $A$, Screen capture of data portal (see https://croplands.org/app/data/search) that provides web access for downloading reference-training and -validation datasets used in machine-learning algorithms; this example shows selection of year-2015 imagery for rice for area in southwestern Mali, West Africa (see Google Earth image in upper right corner). Plot in lower right corner ("NDVI Temporal Profile") contains profiles (green lines) of normalized difference vegetation index (NDVI) time-series signatures at selected locations in the imagery. Profiles show that NDVI begins to rise around June, reaches its peak in September or October, and starts to fall in November, which matches phenology of crop growth that coincides with rainy season (June-0ctober) and, thus, indicates cropland. Note that differences in NDVI magnitude indicate different levels of plant health and (or) vigor at specific locations. $B$, Two-dimensional scatter plot showing principal component 2 (PC2) versus principal component 1 (PC1) values of spectral-band reflectivity of cropland (red dots) and noncropland (green triangles), illustrating how principal-component analysis of spectral-band reflectivity can be used to separate cropland areas from noncropland areas. 


\section{Knowledge-Based Generation}

The knowledge base (see, for example, fig. 6) was generated using reference-training data (see https://croplands.org/app/ data/search) in each of the 74 AEZs (fig. 2) by overlaying the reference-training data in each AEZ (no. 2, in the above section) on the ARD cube of each AEZ (no. 3, in the above section), which resulted in cropland being separated from noncropland (fig. 6) in one or more bands in time-series Landsat 8 and Landsat 7 data. The knowledge base was improved continually by adding and deleting certain sample points that were causing confusion or by mixing between cropland and noncropland. Finally, the retained knowledge base was the one that provided the greatest separability in multiple bands and multiple dates (fig. 6). This knowledge base was then fed to MLAs (see section below) by creating software and computing in the GEE cloud.

\section{Machine-Learning Algorithms}

Machine-learning algorithms (MLAs), which are becoming increasingly popular for classifying very large areas of remotely sensed imagery, include methods such as artificial neural networks, decision trees, support-vector machines (SVMs), and random forests (RFs). MLAs use knowledge (see, for example, fig. 6) to separate cropland classes (Egorov and others, 2015; Xiong and others, 2017c; Teluguntla and others, 2018; Gumma and others, 2019; Oliphant and others, 2019) from other land cover-land use classes by classifying imagery; either supervisedor unsupervised-classification approaches can be adopted. A wide array of MLAs was tested and adopted during this project:

- Random forest (Gislason and others, 2006; Tatsumi and others, 2015; Xiong and others, 2017c; Teluguntla and others, 2018; Oliphant and others, 2019; Phalke and others, 2020);

- Automated cropland-mapping algorithm (Thenkabail and Wu, 2012; Wu and others, 2014a, b; Xiong and others, 2017c; Xie and others, 2019);

- Automated cropland-classification algorithm (Thenkabail and others, 2010; Teluguntla and others, 2017b);

- Spectral-matching technique (Thenkabail and others, 2007b; Velpuri and others, 2009; Dheeravath and others, 2010; Massey, 2017; Teluguntla and others, 2017b);

- Support-vector machine (Mountrakis and others, 2011; Zheng and others, 2015; Xiong and others, 2017c);

- Decision tree (Friedl and Brodley, 1997; DeFries and Chan, 2000; Banfield and others, 2007; Gumma and others, 2011a, b, c, 2019; Brown and others, 2013; Waldner and others, 2015; Massey and others, 2018);

- Linear-discriminant analysis (Imani and Ghassemian, 2015; Phalke and Özdoğan, 2018);
- Principal-component analysis (Jensen, 2007);

- K-means, isoclass clustering (Jensen, 2007; Zhong and others, 2014; Duveiller and others, 2015; Zhang and others, 2015a, 2017);

- Classification and regression tree (Deng and Wu, 2013; Vancutsem and others, 2013; Egorov and others, 2015);

- Tree-based regression algorithm (Ozdogan and Gutman, 2008);

- Phenology-based methods (Dong and others, 2015);

- Fourier harmonic analysis (Geerken and others, 2005; Qiu and others, 2014; Zhang and others, 2015b); and

- Hierarchical image segmentation (Tilton and others 2012; Xiong and others, 2017c).

These MLAs were successfully implemented by writing software and computing in the GEE cloud (Gorelick and others, 2017) and (or) NASA Earth Exchange (NEX) (Nemani and others, 2011), resulting in cropland-extent products for each AEZ, which were later combined to form one seamless global cropland-extent product (fig. 7). However, four key MLAs were used across all AEZs to delineate cropland from noncropland: two pixel-based nonparametric supervised classifiers (random forest [RF] and support-vector machines [SVMs]), an object-oriented classifier, and recursive hierarchical segmentation.

A random forest $(\mathrm{RF})$ is an ensemble classifier that generates a set of multiple decision trees and then votes for the most popular class, using a randomly selected subset of training samples and variables. The RF uses hundreds of classifiers that are built into RF classification, and their decisions are combined, usually by plurality vote, using the premise that accuracy is greater from combining ensemble classifiers than it is from any single ensemble classifier, thereby avoiding conflicts among the feature subsets (Tian and others, 2016). The RF classifier uses bootstrap aggregating (bagging) to form an ensemble of decision trees by searching random subspaces from the given features and the best splitting of the nodes by minimizing the correlation between the decision trees (Xiong and others, 2017c). It provides a means of averaging predictions of multiple decision trees, trained on different subsets of the same data, in order to overcome the problem of overfitting ${ }^{23}$ by individual decision trees (Shah and others, 2019; Kranjčić and others, 2019). Nevertheless, overfitting does occur, resulting in errors of commission (for

\footnotetext{
${ }^{23}$ Overfitting can happen when too many parameters are incorporated into a model, causing the results of an analysis to correspond too closely to a particular dataset and fail to fit other data. Overfitting can also happen when too much data (or too many bands of data) are used in an analysis. For example, analyzing a greater number of spectral bands does not always provide greater clarity. Typically, when many bands are analyzed, the first few bands explain most or all the variability; additional bands either become redundant or explain only a very small (and, often, insignificant) additional variability. One must find the balance between what is optimal and what is beyond optimal; beyond optimal leads to overfitting.
} 





example, mapping noncropland as cropland); to correct for data overfitting, an SVM classifier that has a linear kernel is used in the problematic areas to replace the RF results (Xiong and others, 2017c). However, the overfitting problem can be kept to a minimum in both RF and SVM by carefully selecting pure reference samples and avoiding samples that have any degree of uncertainty. Therefore, it must be noted that purity of samples is more favored than the number of samples. The best approach involves a perfect balance among the number of samples $(n=250$ is adequate for an AEZ), the purity of the samples (best to include the samples in which we have perfect or near-perfect confidence), and the spacing of the samples (spatially well spread out sampling avoids autocorrelation). Furthermore, best results are obtained by limiting classifications within specific AEZs (fig. 2) rather than performing classification across all AEZs because, through iterative processes, we add and subtract reference samples to ensure optimal classification results.

A support-vector machine (SVM) is especially attractive when sample sizes are smaller. It can achieve good classification accuracy when only a few samples exist (Mountrakis and others, 2011), but the samples must be accurate and pure. Also, the SVM has low sensitivity to Hughes phenomenon ${ }^{24}$ (Melgani and Bruzzone, 2002), thus, not requiring feature reduction for data-dimensionality reduction. In contrast, RF ensemble decision trees require as large a sample size as possible to ensure the ensemble process has many trees from which to make best decisions for a class, which is problematic when obtaining large and well-distributed samples in a resource-constrained environment. In this project, the sample size for cropland versus noncropland was large, accurate, and well distributed, making $\mathrm{RF}$ an ideal classifier; however, RF still results in overfitting in many places, leading to higher user's accuracies (that is, larger errors of commission). As a result, this produces higher producer's accuracies (that is, lower errors of omission), which is deceptive in the sense that, in the process, significant areas that are not cropland are mapped as cropland (increasing errors of commission). But an ideal classification result is one in which a good balance between producer's and user's accuracies exists (or when omission and commission errors are kept to a minimum and, thus, balance out). This project adopted the following approach:

- Use RF MLAs to classify and discern cropland from noncropland;

\footnotetext{
${ }^{24}$ The Hughes phenomenon — also known as the curse of high-dimensionality data - occurs when, as the number of bands in classifications increases, the classification accuracies increase as well, until a point when any further increase in the number of bands either makes accuracies asymptotic or accuracies begin to decrease. A greater number of bands can provide greater numbers of classesand also greater numbers of accuracies — only when the number of training and validation samples is adequate. However, when bands are many and classes are many, the training and validation samples also need to increase exponentially, which is not always possible owing to resource needs, logistical issues, and timeliness of gathering data over large geographic extents. Without such rich training and validation data, more bands of data may be a curse, rather than a boon. Therefore, researchers have often opted to reduce data dimensionality by eliminating redundant bands for a given application and retaining nonredundant bands, which provides an optimal solution (Thenkabail and others, 2021).
}

- Address any overfitting issues by running SVM MLA classification; and

- Synthesize the final classification result using both RF and SVM classifier outputs, comparing them, and ensuring removal of any overfitting, thereby reducing errors of commission to a minimum and balancing the errors of omission and commission to the optimum.

Furthermore, despite the best efforts, the results of pixel-based classifications (RF, SVM), in practice, inevitably include "salt and pepper" noise and disjointed farm fragments (Xiong and others, 2017c). In these cases, object-based classifications such as the Recursive Hierarchical Segmentation (RHSEG) (Tilton and others, 2012) can improve "salt and pepper" effects and increase classification accuracies more than can pixel-based image classifications, which ignore similarity of adjoining pixels (Xiong and others, 2017c). Object-oriented image segmentation gathers several similar, neighboring pixels together as objects, and the RHSEG image classification categorizes or labels the objects, which would then be further labelled as cropland or noncropland in the integration step with pixel-based classification (Xiong and others, 2017c).

The typical process of pixel-based MLAs and object-based RHSEG classifiers used in this study involved the following 12 key steps (fig. 5):

1. Start with a known AEZ (fig. 2) when using Landsat 8 and Landsat 7 ARD data cube (fig. 3);

2. Choose reference-training data (https://croplands.org/ app/data/search);

3. Generate a knowledge base to separate cropland from noncropland (fig. 6);

4. Create pixel-based supervised MLAs such as RF and SVMs in the GEE cloud, using Python and JavaScript;

5. Run pixel-based MLAs using the ARD data cube in the GEE cloud for each AEZ;

6. Evaluate cropland and noncropland classes to ensure accurate classification;

7. If classification accuracies are not sufficiently high, further evaluate the reference-training data and subtract samples that cause problems or add additional samples to improve the classification accuracies;

8. Reiterate steps 4 to 6 ;

9. Optimize classification results of RF and SVM by removing any overfitting issues;

10. Run object-oriented RHSEG algorithm to classify the same area as above, to ensure "salt and pepper" noise is removed and to find any possible additional improvement to the RF and SVM classifier results; 
11. Synthesize the pixel-based-classifier (RF, SVM) results with object-based-classifier (RHSEG) results into a unified classification result; and

12. Stop when adequate overall producer's and user's accuracies are achieved.

\section{Accuracies, Errors, and Uncertainties}

Accuracies were evaluated by an independent accuracyassessment team (see Congalton and others, 2017; Yadav and Congalton, 2018, 2019), who had access to 19,171 validation samples that were blinded for the producers. The validation samples were different from the training samples and were not used in training the MLAs or in class identification.

Accuracies were assessed by generating traditional error matrices (Congalton and Green, 2009; Congalton, 2015). An error matrix (table 3) derives both accuracies and errors and is expressed as a percentage. Overall accuracy is obtained by dividing the correctly classified samples (found along the diagonal of an error matrix) by the total number of reference-validation samples $(\mathrm{N})$ used in the error matrix (table 3). Overall accuracy is map accuracy, as it considers all classes in the map. For example, in a total of 600 reference-validation samples $(\mathrm{N}=600)$ in table 3 , the correctly classified samples in the map that are found along the diagonal total to 550, resulting in an overall accuracy of 92 percent.

Every error matrix provides two other accuracies (table 3), producer's accuracy and user's accuracy (Story and Congalton, 1986), which are calculated for every individual class in the map:

- Producer's accuracy is the number of correctly classified samples for each class divided by the total number of samples in the corresponding column. Producer's accuracy is also an accuracy from the map producer's perspective in which a land-cover class such as cropland on the ground is shown as cropland on the map, and it avoids capturing noncropland as cropland. However, in the process, producer's accuracy omits some cropland that should have been, but was not, mapped as cropland.

- User's accuracy is the number of correctly classified samples for each class divided by the total number of samples in the corresponding row. User's accuracy is also an accuracy from the map user's perspective in which a land-cover class such as cropland on the map will be present on the ground, hence, referring to reliability. When user's accuracy is high, the class in consideration, such as cropland mapped as cropland, is also high. However, in the interest of getting every pixel of a class correct, the likelihood that a noncropland pixel is mapped as a cropland pixel often increases as well.

In addition, every error matrix provides two types of errors (table 3), errors of omissions and errors of commissions. These errors, which are calculated for every individual class in the map, are inverse of the producer's and user's accuracies, in that, if a sample is committed to an incorrect map class, it is omitted from the correct one:

- Errors of omission reflect an underestimation of the class - that is, the recognition that some of the class is not mapped into that class - hence, omitted errors. Errors of omissions (EO) are assessed for each class: $\mathrm{EO}$ (as a percentage $)=100-$ producer's accuracies (PA, as a percentage), or EO $=100-\mathrm{PA}$. In table 3 , 20 cropland samples are assigned as noncropland, whereas 230 samples are correctly assigned as cropland. Therefore, producer's accuracy for the cropland class is 92 percent, and the error of omission for the cropland class is 8 percent.

Table 3. Example of an accuracy confusion error matrix, which has been developed for each of 74 agroecological zones for assessing accuracies of cropland classification so that accuracies can be understood locally as well as globally.

$[\mathrm{N}$, number of reference-validation samples; values in blue-shaded cells are numbers of correctly classified pixels. Errors of commission $(\%)=100-$ user's accuracy $(\%)$. Errors of omission $(\%)=100-$ producer's accuracy $(\%)$. Overall accuracy $(\%)=$ total number of correctly classified samples divided by total number of samples (for example, $550 \div 600=92 \%$ ). --, not applicable]

\begin{tabular}{|c|c|c|c|c|c|}
\hline \multirow[b]{2}{*}{ Class } & \multicolumn{3}{|c|}{ Reference-validation data } & \multicolumn{2}{|c|}{ Accuracies } \\
\hline & Cropland (N) & Noncropland (N) & Total (N) & $\begin{array}{c}\text { User's accuracy } \\
(\%)\end{array}$ & $\begin{array}{c}\text { Errors of } \\
\text { commission (\%) }\end{array}$ \\
\hline Noncropland & 20 & 320 & 340 & 94 & 6 \\
\hline Total & 250 & 350 & 600 & -- & -- \\
\hline Producer's accuracy (\%) & 92 & 91 & -- & -- & -- \\
\hline \multirow[t]{2}{*}{ Errors of omission (\%) } & 8 & 9 & -- & -- & -- \\
\hline & & Overall accuracy (\%) & 92 & -- & -- \\
\hline
\end{tabular}


- Errors of commission reflect an overestimation of the class - that is, the recognition that some areas of another class are mapped as this class-hence, committed errors. Errors of commission (EC) are assessed for each class: $\mathrm{EC}$ (as a percentage) $=100$ - user's accuracies (UA, as a percentage), or EC $=100-\mathrm{UA}$. In table 3, 30 noncropland samples are assigned as cropland, whereas 230 samples are correctly assigned as cropland. Therefore, user's accuracy for the cropland class is 88 percent, and the error of commission for the cropland class is 12 percent.

When developing algorithms, it is essential to keep both producer's accuracies versus user's accuracies and errors of omission versus errors of commission in balance (optimal). Increasing one accuracy often leads to a decrease in another accuracy; similarly, a reduction in one error leads to an increase in another error.

In this study, error matrices were run for each of the 74 AEZs, using reference validation data of 19,171 samples $(\mathrm{N}=19,171)$, by an independent group (Congalton and others, 2017). These validation data were not available to Congalton and others (2014), who were the producers of the mapping product. During initial evaluations, as well as during various team meetings, Congalton and others (2014) established that about 250 samples per class per AEZ provided optimal accuracies. Having quality validation datasets that have samples that are spatially well distributed was more important than simply having a large sample size. Beyond 250 samples per class per AEZ, the accuracies plateaued. In some regions of the world (Gumma and others, 2019), accuracy assessments were conducted separately from the global effort, as a result of product refinements at a later date.

\section{Area Comparisons}

Once the cropland-extent product was produced with sufficient accuracies (see previous section), cropland areas were computed for various administrative or other types of units. Because the global cropland-extent product is at 30-m (GCEP30) spatial resolution, even areas of very small administrative units such as villages can be computed; however, we calculated areas of administrative units for which we have comparative areas from other international and national sources. The GCEP30 cropland-extent product represents net-cropland areas (NCAs) for the countries and global net-cropland areas (GNCAs).

GNCAs or NCAs, which are simply referred to as cropland areas, are calculated for both countries and subnational areas (for example, territories, departments, provinces, or districts), and they are compared with corresponding statistics from other conventional sources. First, national cropland-area statistics were compared with corresponding data from UN FAOSTAT (FAO, 2019b; see, for example, http://www.fao.org/faostat/en/\#home). Countrywise, cropland areas were also compared with global dataset of monthly irrigated and rainfed crop areas (MIRCA)
(Portmann and others, 2010; also, additional data from Stefan Siebert [coauthor of Portmann and others, 2010], University of Göttingen, Germany, written commun., 2016), global irrigated area map (GIAM) (Thenkabail and others, 2011), global map of rainfed cropland areas (GMRCA) (Biradar and others, 2009), and global rainfed, irrigated, and paddy croplands (GRIPC) (Salmon and others, 2015). In addition, we compared subnational cropland statistics of a number of countries, such as China, India, Indonesia, Thailand, Philippines, and South Korea, with corresponding national statistics.

\section{Results and Discussions}

The global food-security-support-analysis data at 30-m resolution (GFSAD30) project (www.usgs.gov/wgsc/gfsad30) produced the first global cropland-extent product at 30-m resolution (GCEP30; fig. 7) on the basis of data and methods described in the sections above entitled, "Data" and "Methods." This section presents the GCEP30 map product; discusses the accuracies, errors, and uncertainties of GCEP30; compares areas of all the countries of the world, as well as areas of subnational administrative units where comparisons are possible; and compares spatial extent of cropland mapped by GCEP30 with a few other well-established products at coarser resolution. It must be noted that recent global nominal-30-m-resolution landcover products include cropland versus other land-cover classes such as fine resolution observation and monitoring of global land cover (FROM-GLC), 30-m-resolution global land-cover dataset (Globeland30), and finer resolution observation and monitoring of global cropland (FROM-GC) (table 1); however, none are exclusively for cropland. Other products have cropland classes as one of the classes, often mixed with grazing land or pastureland and, sometimes, rangeland or grassland, which leads to uncertainties in both the precision and accuracies of the cropland class.

\section{Global Cropland-Extent Map at 30-m Resolution (GCEP30) Derived from Landsat}

The GCEP30 product (fig. 7) was composed by putting together regional and continental products made available in USGS' and NASA's Land Processes Distributed Active Archive Center (LP DAAC) (USGS and NASA, 2017; see https://lpdaac.usgs.gov/news/release-of-gfsad-30metercropland-extent-products/; see also, table 3 of this report for references). The full-resolution view of the GCEP30 product (fig. 7) is available at www.croplands.org. The 30-m-resolution GCEP30 is the first Landsat-satellite-derived, high-resolution, global cropland-extent map (GCEP30), and it is the highest known resolution global cropland-extent product ever mapped. The product is derived using multiyear data (table 2) for the years around and including 2015: GCEP30 is referred to as the nominal-year 2015 or, simply, a year-2015 product. The GCEP30 cropland-extent product (fig. 7; see 
also, USGS and NASA, 2017; https://pdaac.usgs.gov/news/ release-of-gfsad-30-meter-cropland-extent-products/; www. croplands.org) allows the user to zoom into in any place in the world (fig. 8) and view in full resolution; it has cropland as per the definition (fig. 1). However, in five countries (Argentina, Australia, Brazil, Kazakhstan, and New Zealand), the GCEP30 has croplands and managed pasturelands included. Because these two land-cover classes often are adjacent to each other and represent large areas, we retained managed pasturelands along with cropland extent for these five countries. However, the cropland areas reported for all countries (excluding these five countries) only consist of cropland (that is, they do not include managed pasturelands).

Figure 8 illustrates examples of the zoomed-in view of GCEP30 and compares it to the submeter- to 5-m-resolution background imagery. In figure 8, cropland is captured in detail, mapping small and large farms anywhere in the world. The reference submeter- to 5-m-resolution image is compared to the zoomed-in view of GCEP30 in three distinct areas of the world: Paardenberg, South Africa; near Laguna Las Tunas Grandes, Argentina; and Aksu Prefecture, China. These views illustrate the level of detail in separating cropland from noncropland.

Mapping cropland in such great detail (figs. 7, 8) and accuracies (see next section below) is the first step towards accurately mapping all higher level cropland-extent products such as crop types, irrigated versus rainfed crops, cropping intensities, crop productivities, and crop-water productivities. For all these higher level products, the baseline data are the cropland-extent product such as GCEP30. The real strength of the GCEP30 product is that it captures fragmented farms and small farms equally as well, given its high resolution of $30 \mathrm{~m}$ per pixel. The ability to view the entire world's cropland in full resolution enables us to zoom in to any individual farm or group of farms and study their within- and across-season (or within- and across-year) dynamics. Such a product will help us study croplands in terms of their geolocation, farm size (small or big), and distribution across countries, regions, continents, and the world. Notably, croplands in figure 7 for some countries (for example, in Bangladesh, India, and a number of European countries) seem to cover the entire country, or most of it; however, when you zoom in (fig. 8), areas of cropland are clearly distinguished from noncropland areas.

\section{Accuracies, Errors, and Uncertainties of Global Cropland-Extent Map at 30-m Resolution (GCEP30) Derived from Landsat}

Comprehensive accuracy assessments were performed for each of the 74 AEZs (Congalton and others, 2017), and, for every AEZ, an error matrix produced overall accuracies, producer's accuracies, and user's accuracies. The accuracies reported in Congalton and others (2017) are represented in three global cropland-extent maps: overall accuracies (fig. 9), producer's accuracies (fig. 10), and user's accuracies (fig. 11).

For the entire world, the global cropland-extent product at 30-m resolution (GCEP30; fig. 7) has an overall accuracy of 91.7 percent (table 4; see also, fig. 9). For the cropland class, the producer's accuracy is 83.4 percent (errors of omission, 16.6 percent)
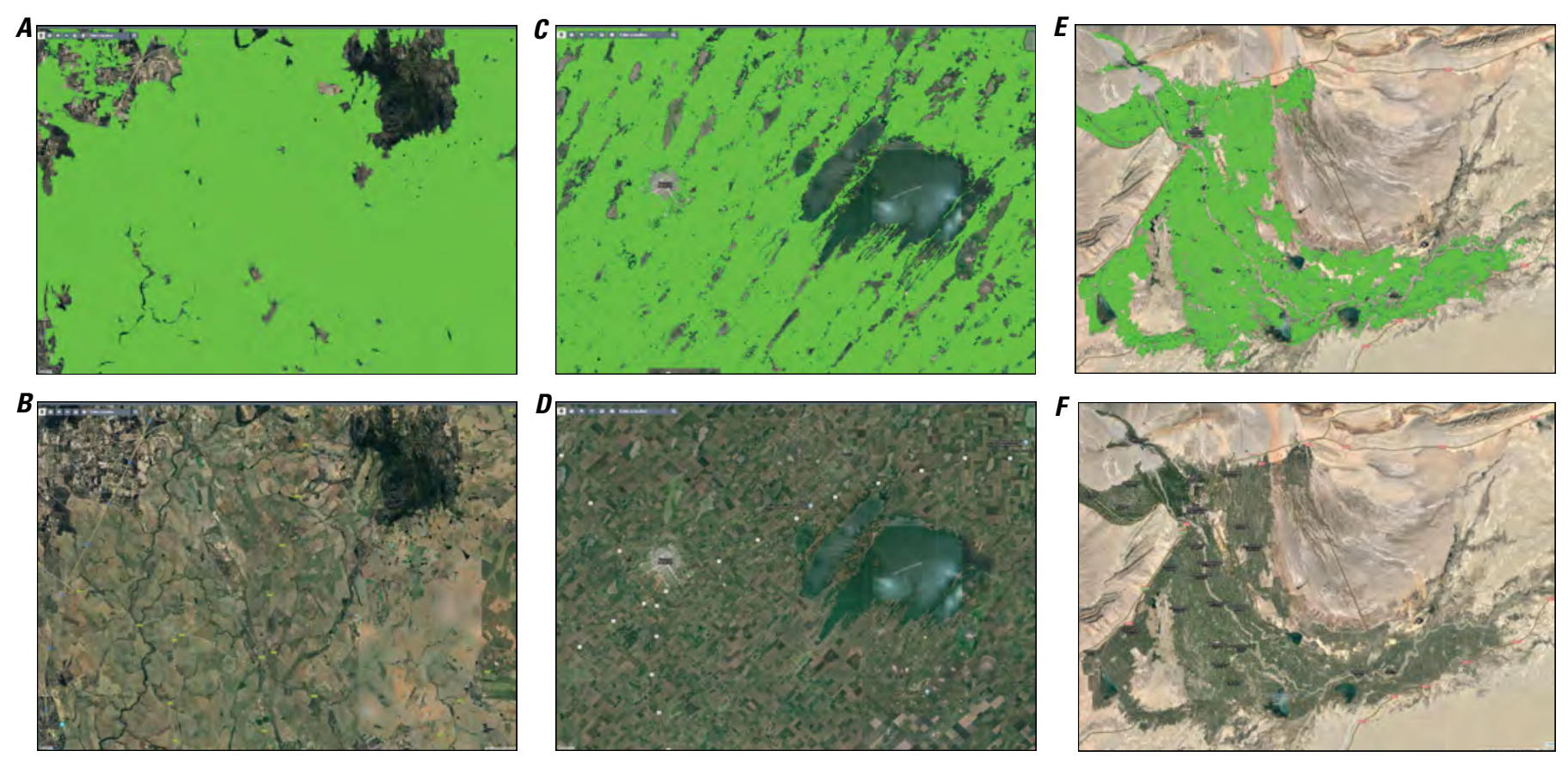

Figure 8. Screen captures of close-up views of global cropland-extent product at 30-m resolution (GCEP30; see fig. 7), showing distribution of cropland (green shading) as mapped on submeter- to 5-m-resolution very high resolution imagery (VHRI). Views are of mapped (top) and unmapped (bottom) images of Paardenberg, South Africa $(A, B$, respectively); near Laguna Las Tunas Grandes, Argentina ( $C, D$, respectively); and Aksu Prefecture, China ( $E, F$, respectively). Base map images from Google Earth (used with permission). 




Figure 9. Map showing overall accuracies of agroecological zones (AEZs) for nominal-year 2015. Accuracies derived from global cropland-extent product at 30-m resolution (GCEP30).

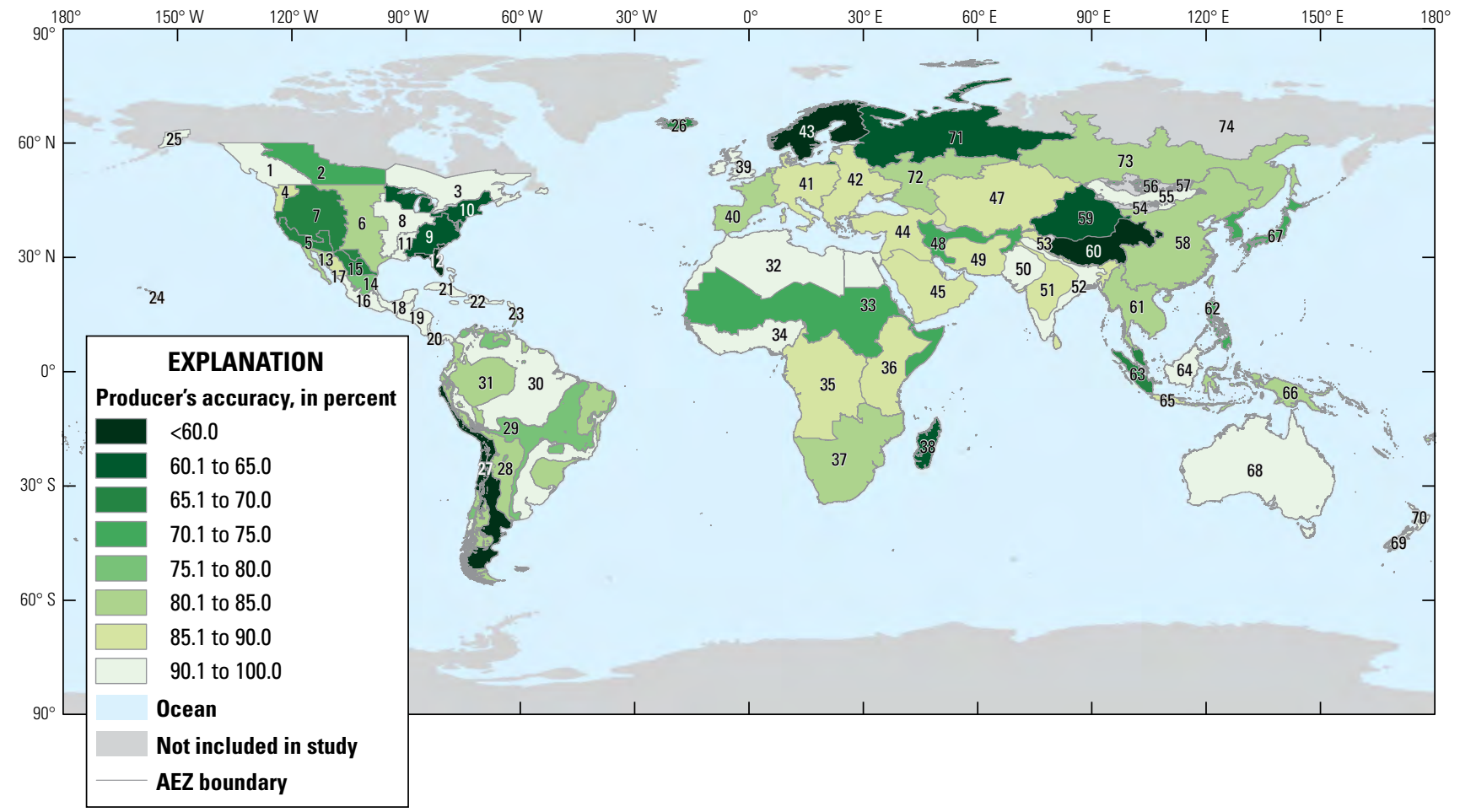

Figure 10. Map showing producer's accuracies of cropland in global cropland-extent product at 30-m resolution (GCEP30) for all 74 agroecological zones (AEZs). Note that errors of omission $(\%)=100$ - producer's accuracy (\%). 


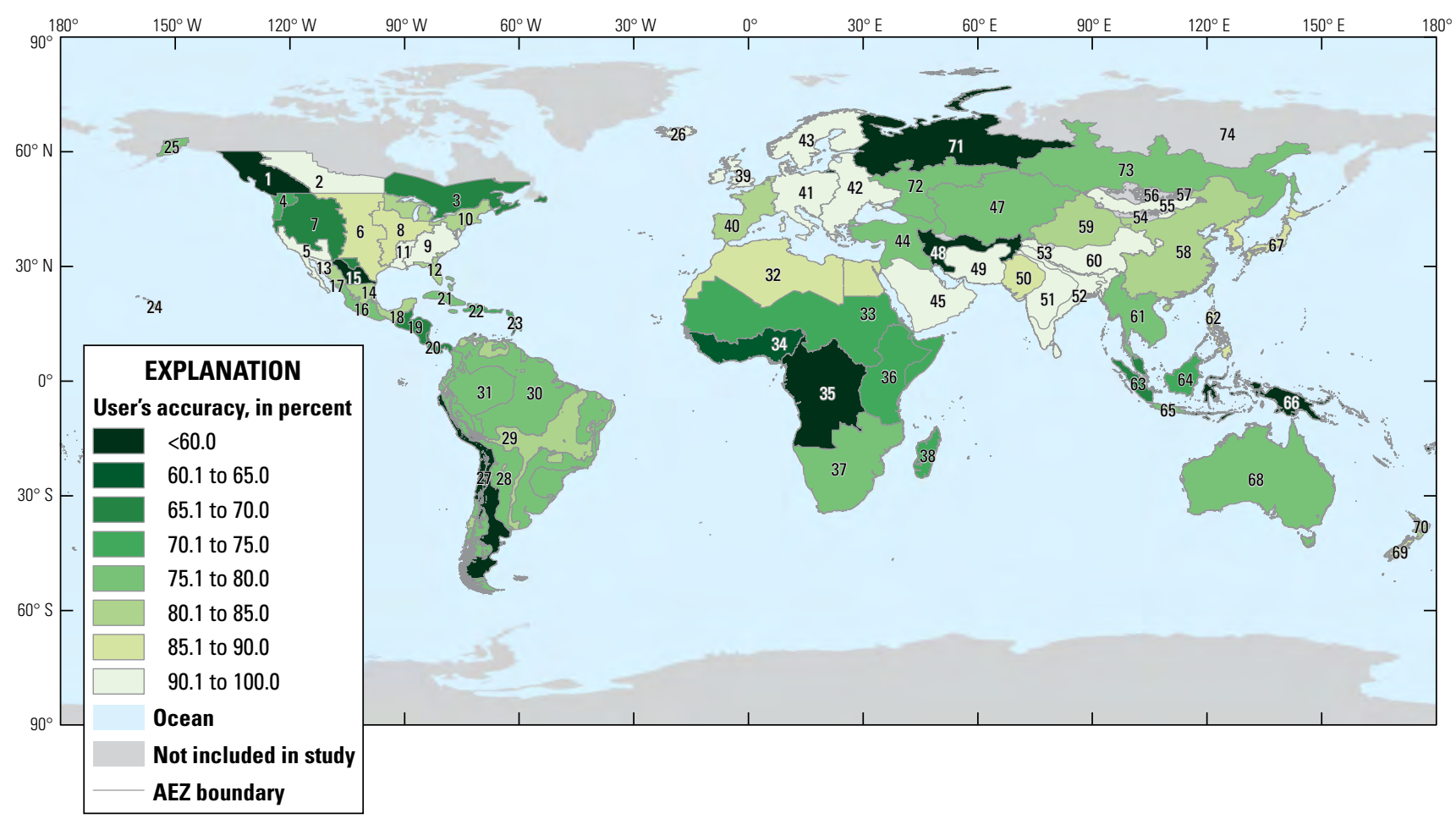

Figure 11. Map showing user's accuracies of cropland in global cropland-extent product at 30-m resolution (GCEP30) for all 74 agroecological zones (AEZs). Note that errors of commission $(\%)=100-$ user's accuracy $(\%)$.

(table 4; see also, fig. 10), and the user's accuracy is 78.3 percent (errors of commission, 21.7 percent) (table 4; see also, fig. 11). The above results mean that, for the entire global cropland-extent product, 16.6 percent of the cropland is missing, and 21.7 percent of noncropland is mapped as cropland.

The overall accuracies for much of the world is more than 85 percent (fig. 9), which demonstrates the high degrees of accuracy with which cropland is distinguished from noncropland. Only five of 74 AEZs (AEZ nos. 40, 50, 51, 52, and 72) have relatively lower overall accuracies of around 75 percent (fig. 9).

For the cropland class, the producer's accuracies of an overwhelming proportion of the world is above 85 percent (errors of omission, less than 15 percent) (fig. 10). The user's accuracies of an overwhelming proportion of the world are also above 85 percent (errors of commission, less than 15 percent) (fig. 11). Sometimes when capturing as much cropland as possible (to keep omission errors of cropland class low or producer's accuracies high), a significant amount of noncropland gets mapped as cropland (to keep commission errors of cropland class low or user's accuracies high). Ideally, in every AEZ, the goal must be to obtain a balance between producer's and user's accuracies, retaining both as high as possible, or keeping both omission and commission errors as low as possible.

We also have shown a few error matrices to illustrate how accuracy error matrices work. For the entire continent of Africa, the overall weighted accuracies are 94.5 percent, with an Fscore ${ }^{25}$ of 0.76 . For the cropland class, the producer's accuracy is 85.9 percent (errors of omission, 14.1 percent), and the user's accuracy is 68.5 percent (errors of commission, 31.5 percent) (table 5). Both producer's accuracies and overall accuracies of Africa are high. However, for the cropland class to achieve high producer's accuracies, the user's accuracies had to be compromised. The MLAs are written in such a way as to best balance producer's and user's accuracies. However, because the goal here is to capture as much cropland as possible, compromises need to be made at times to achieve high producer's accuracies for the cropland class by having lower user's accuracies - it is always a trade-off.

This issue is even more dramatic in Australia (table 6), which has excellent overall accuracies (97.6 percent) and producer's accuracies (98.8 percent); indeed, only 1.2 percent of cropland is missing (errors of omission) in the GCEP30 (fig. 7). However, this was possible by having a higher error of commissions of 21 percent (that is, more noncropland was mapped as cropland, leading to a user's accuracy of 79 percent) (table 6). If we tweak the MLAs, it is possible to increase the user's accuracies of Australia significantly, but that can happen only with a decrease in the producer's accuracies, which means we will be missing some of the cropland.

A greater balance of producer's and user's accuracies exists for China, which has a producer's accuracy of 80 percent (errors of omission, 20 percent), a user's accuracy of 84.2 percent 
Table 4. Accuracy confusion error matrix for entire global cropland-extent map at 30-m resolution (GCEP30), used for assessing accuracies of cropland classification so that accuracies can be understood locally as well as globally.

[GCEP30 accuracy assessment is from Congalton and others (2017). N, number of reference-validation samples; values in blue-shaded cells are numbers of correctly classified pixels. Errors of commission (\%) $=100$ - user's accuracy $(\%)$. Errors of omission $(\%)=100-$ producer's accuracy $(\%)$. Overall accuracy $(\%)=$ total number of correctly classified samples divided by total number of samples (for example, $17,581 \div 19,171=91.7 \%$ ). --, not applicable]

\begin{tabular}{|c|c|c|c|c|c|}
\hline \multirow[b]{2}{*}{ Class } & \multicolumn{3}{|c|}{ Reference-validation data } & \multicolumn{2}{|c|}{ Accuracies } \\
\hline & Cropland (N) & Noncropland (N) & Total (N) & $\begin{array}{c}\text { User's accuracy } \\
(\%)\end{array}$ & $\begin{array}{c}\text { Errors of } \\
\text { commission (\%) }\end{array}$ \\
\hline Cropland & 3,339 & 924 & 4,263 & 78.3 & 21.7 \\
\hline Noncropland & 666 & 14,242 & 14,908 & 95.5 & 4.5 \\
\hline \multirow[t]{2}{*}{ Total } & 4,005 & 15,166 & 19,171 & -- & -- \\
\hline & \multicolumn{2}{|c|}{ Correctly classified (diagonal total) } & 17,581 & -- & -- \\
\hline \multicolumn{6}{|c|}{ Accuracies } \\
\hline Producer's accuracy (\%) & 83.4 & 93.9 & -- & -- & -- \\
\hline \multirow[t]{2}{*}{ Errors of omission $(\%)$} & 16.6 & 6.1 & -- & -- & -- \\
\hline & & Overall accuracy (\%) & 91.7 & -- & -- \\
\hline
\end{tabular}

Table 5. Accuracy confusion error matrix for global cropland-extent map of Africa (all zones), used for assessing accuracies of cropland classification so that accuracies can be understood locally as well as globally.

[N, number of reference-validation samples; values in blue-shaded cells are numbers of correctly classified pixels. Errors of commission ( $\%)=100-$ user's accuracy ( $\%)$. Errors of omission $(\%)=100$ - producer's accuracy $(\%)$. Overall accuracy $(\%)=$ total number of correctly classified samples divided by total number of samples (for example, $1,640 \div 1,750=93.7 \%)$. --, not applicable]

\begin{tabular}{|c|c|c|c|c|c|}
\hline \multirow[b]{2}{*}{ Class } & \multicolumn{3}{|c|}{ Reference-validation data } & \multicolumn{2}{|c|}{ Accuracies } \\
\hline & Cropland (N) & Noncropland (N) & Total (N) & $\begin{array}{c}\text { User's accuracy } \\
(\%)\end{array}$ & $\begin{array}{c}\text { Errors of } \\
\text { commission (\%) }\end{array}$ \\
\hline Noncropland & 29 & 1,464 & 1,493 & 98.1 & 1.9 \\
\hline \multirow[t]{2}{*}{ Total } & 205 & 1,545 & 1,750 & -- & -- \\
\hline & \multicolumn{2}{|c|}{ Correctly classified (diagonal total) } & 1,640 & -- & -- \\
\hline Producer's accuracy (\%) & 85.9 & 94.8 & -- & -- & -- \\
\hline \multirow[t]{3}{*}{ Errors of omission (\%) } & 14.1 & 5.2 & -- & -- & -- \\
\hline & & Overall accuracy $(\%)$ & 93.7 & -- & -- \\
\hline & & Weighted accuracy (\%) & 94.5 & & \\
\hline
\end{tabular}

Table 6. Accuracy confusion error matrix for global cropland-extent map of Australia, used for assessing accuracies of cropland classification so that accuracies can be understood locally as well as globally.

$[\mathrm{N}$, number of reference-validation samples; values in blue-shaded cells are numbers of correctly classified pixels. Errors of commission ( $\%)=100-$ user's accuracy $(\%)$. Errors of omission $(\%)=100$ - producer's accuracy (\%). Overall accuracy $(\%)=$ total number of correctly classified samples divided by total number of samples (for example, $878 \div 900=97.6 \%$ ). --, not applicable]

\begin{tabular}{|c|c|c|c|c|c|}
\hline \multirow[b]{2}{*}{ Class } & \multicolumn{3}{|c|}{ Reference-validation data } & \multicolumn{2}{|c|}{ Accuracies } \\
\hline & Cropland (N) & Noncropland (N) & Total (N) & $\begin{array}{c}\text { User's accuracy } \\
(\%)\end{array}$ & $\begin{array}{c}\text { Errors of } \\
\text { commission (\%) }\end{array}$ \\
\hline Noncropland & 1 & 799 & 800 & 99.9 & 0.1 \\
\hline \multirow[t]{2}{*}{ Total } & 80 & 820 & 900 & -- & -- \\
\hline & \multicolumn{2}{|c|}{ Correctly classified (diagonal total) } & 878 & -- & -- \\
\hline Producer's accuracy (\%) & 98.8 & 97.4 & -- & -- & -- \\
\hline \multirow[t]{2}{*}{ Errors of omission (\%) } & 1.2 & 2.6 & -- & -- & -- \\
\hline & & Overall accuracy (\%) & 97.6 & -- & -- \\
\hline
\end{tabular}


(errors of commission, 15.8 percent), and an overall accuracy of 94 percent (table 7). On the global producer's accuracy map (fig. 10), in AEZ 60, which is in China, producer's accuracy is quite low (less than 60 percent). However, 95 percent of China's agriculture is in AEZ 58; 3 percent is in AEZ 59; and less than 2 percent is in AEZ 60 (fig. 10). Therefore, the high producer's and user's accuracies in AEZ 58 of more than 80 percent (fig. 10) is the most important factor. Indeed, this is the case throughout the world where overall accuracies (fig. 9), producer's accuracies (fig. 10), and user's accuracies (fig. 11) in GCEP30 (fig. 7) were high for all AEZs that have a high percentage of cropland. Typically, in some AEZs that have a very low percentage of cropland areas, the producer's or user's accuracies are somewhat low (figs. 10,11). Error matrices for all 74 AEZs are provided in table 8 , and they are mapped in figures 9,10 , and 11 .

Table 7. Accuracy confusion error matrix for global cropland-extent map of China, used for assessing accuracies of cropland classification so that accuracies can be understood locally as well as globally.

$[\mathrm{N}$, number of reference-validation samples; values in blue-shaded cells are numbers of correctly classified pixels. Errors of commission $(\%)=100-$ user's accuracy (\%). Errors of omission (\%) $=100$ - producer's accuracy $(\%)$. Overall accuracy $(\%)=$ total number of correctly classified samples divided by total number of samples (for example, $1,853 \div 1,972=94 \%$ ). --, not applicable]

\begin{tabular}{|c|c|c|c|c|c|}
\hline \multirow[b]{2}{*}{ Class } & \multicolumn{3}{|c|}{ Reference-validation data } & \multicolumn{2}{|c|}{ Accuracies } \\
\hline & Cropland (N) & Noncropland (N) & Total (N) & $\begin{array}{c}\text { User's accuracy } \\
(\%)\end{array}$ & $\begin{array}{c}\text { Errors of } \\
\text { commission (\%) }\end{array}$ \\
\hline Noncropland & 68 & 1,581 & 1,649 & 95.9 & 4.1 \\
\hline \multirow[t]{2}{*}{ Total } & 340 & 1,632 & 1,972 & -- & -- \\
\hline & \multicolumn{2}{|c|}{ Correctly classified (diagonal total) } & 1,853 & -- & -- \\
\hline Producer's accuracy $(\%)$ & 80.0 & 96.9 & -- & -- & -- \\
\hline \multirow[t]{2}{*}{ Errors of omission $(\%)$} & 20.0 & 3.1 & -- & -- & -- \\
\hline & & Overall accuracy $(\%)$ & 94.0 & -- & -- \\
\hline
\end{tabular}

Table 8. Accuracies of all 74 agroecological zones for global cropland-extent product at 30-m resolution (GCEP30).

[Agroecological zones (AEZs) from Congalton and others (2017). GCEP30 (global cropland-extent map at 30-m resolution) shown in figure 7 (available at full resolution at www.croplands.org). Other abbreviation: no., number]

\begin{tabular}{|c|c|c|c|c|c|c|}
\hline Region & AEZ no. & $\begin{array}{c}\text { Producer's } \\
\text { accuracy of } \\
\text { cropland class (\%) }\end{array}$ & $\begin{array}{c}\text { Errors of omission } \\
\text { of cropland class } \\
(\%)\end{array}$ & $\begin{array}{c}\text { User's accuracy } \\
\text { of cropland } \\
\text { class }(\%)\end{array}$ & $\begin{array}{c}\text { Errors of } \\
\text { commission of } \\
\text { cropland class (\%) }\end{array}$ & $\begin{array}{c}\text { Overall } \\
\text { accuracy } \\
(\%)\end{array}$ \\
\hline Canada & 1 & 100.0 & 0.0 & 33.3 & 66.7 & 99.2 \\
\hline Canada & 3 & 100.0 & 0.0 & 66.7 & 33.3 & 98.8 \\
\hline United States & 4 & 85.7 & 14.3 & 72.0 & 28.0 & 96.0 \\
\hline United States & 7 & 69.2 & 30.8 & 69.2 & 30.8 & 96.8 \\
\hline United States & 8 & 90.9 & 9.1 & 89.9 & 10.1 & 92.4 \\
\hline United States & 9 & 61.5 & 38.5 & 94.1 & 5.9 & 95.6 \\
\hline United States & 10 & 62.2 & 37.8 & 84.8 & 15.2 & 91.2 \\
\hline United States & 11 & 91.4 & 8.6 & 91.4 & 8.6 & 96.0 \\
\hline Central America & 15 & 70.0 & 30.0 & 58.3 & 41.7 & 93.5 \\
\hline Central America & 16 & 91.4 & 8.6 & 76.8 & 23.2 & 91.3 \\
\hline Central America & 17 & 88.0 & 12.0 & 84.6 & 15.4 & 97.2 \\
\hline Central America & 18 & 94.0 & 6.0 & 81.0 & 19.0 & 93.9 \\
\hline Central America & 19 & 94.2 & 5.8 & 65.7 & 34.3 & 84.8 \\
\hline Central America & 20 & 100.0 & 0.0 & 69.3 & 30.7 & 90.7 \\
\hline Central America & 21 & 90.9 & 9.1 & 79.5 & 20.5 & 89.8 \\
\hline
\end{tabular}


Table 8.-Continued

\begin{tabular}{|c|c|c|c|c|c|c|}
\hline Region & AEZ no. & $\begin{array}{c}\text { Producer's } \\
\text { accuracy of } \\
\text { cropland class (\%) }\end{array}$ & $\begin{array}{c}\text { Errors of omission } \\
\text { of cropland class } \\
(\%)\end{array}$ & $\begin{array}{l}\text { User's accuracy } \\
\text { of cropland } \\
\text { class }(\%)\end{array}$ & $\begin{array}{c}\text { Errors of } \\
\text { commission of } \\
\text { cropland class (\%) }\end{array}$ & $\begin{array}{c}\text { Overall } \\
\text { accuracy } \\
(\%)\end{array}$ \\
\hline Central America & 22 & 96.0 & 4.1 & 70.3 & 29.7 & 86.7 \\
\hline Central America & 23 & 79.1 & 20.9 & 61.8 & 38.2 & 87.8 \\
\hline United States & 24 & 90.0 & 10.0 & 81.8 & 18.2 & 95.2 \\
\hline United States & 25 & 100.0 & 0.0 & 80.0 & 20.0 & 99.6 \\
\hline Iceland & 26 & 68.4 & 31.6 & 100.0 & 0.0 & 97.6 \\
\hline South America & 27 & 50.0 & 50.0 & 37.5 & 62.5 & 96.8 \\
\hline South America & 28 & 83.3 & 16.7 & 75.8 & 24.2 & 94.8 \\
\hline South America & 29 & 79.6 & 20.4 & 81.3 & 18.8 & 92.4 \\
\hline South America & 30 & 90.9 & 9.1 & 78.4 & 21.6 & 94.0 \\
\hline South America & 31 & 80.8 & 19.2 & 77.8 & 22.2 & 95.6 \\
\hline Africa & 32 & 91.5 & 8.5 & 89.6 & 10.4 & 96.4 \\
\hline Africa & 33 & 72.4 & 27.6 & 72.4 & 27.6 & 93.6 \\
\hline Africa & 34 & 94.9 & 5.1 & 63.8 & 36.2 & 90.8 \\
\hline Africa & 35 & 88.9 & 11.1 & 53.3 & 46.7 & 96.8 \\
\hline Africa & 36 & 89.8 & 10.2 & 72.1 & 27.9 & 91.3 \\
\hline Africa & 37 & 84.6 & 15.4 & 80.0 & 20.0 & 94.8 \\
\hline Africa & 38 & 60.7 & 39.3 & 70.8 & 29.2 & 92.8 \\
\hline United Kingdom, Ireland & 39 & 92.3 & 7.7 & 91.2 & 8.8 & 88.8 \\
\hline East Europe & 40 & 82.2 & 17.8 & 84.3 & 15.7 & 79.2 \\
\hline Mid Europe & 41 & 87.8 & 12.2 & 92.3 & 7.7 & 87.2 \\
\hline West Europe & 42 & 87.3 & 12.7 & 93.0 & 7.1 & 87.2 \\
\hline North Europe & 43 & 40.5 & 59.5 & 93.8 & 6.3 & 90.8 \\
\hline North Middle East & 44 & 89.7 & 10.3 & 79.8 & 20.2 & 87.2 \\
\hline South Middle East & 45 & 88.9 & 11.1 & 100.0 & 0.0 & 99.6 \\
\hline Central Asia & 47 & 90.0 & 10.0 & 76.6 & 23.4 & 94.0 \\
\hline South Asia, Iran, Afghanistan & 48 & 71.2 & 28.8 & 56.8 & 43.2 & 80.4 \\
\hline South Asia, Iran, Afghanistan & 49 & 89.3 & 10.7 & 92.6 & 7.4 & 87.8 \\
\hline South Asia, Iran, Afghanistan & 50 & 91.6 & 8.4 & 89.7 & 10.3 & 88.0 \\
\hline South Asia, Iran, Afghanistan & 51 & 87.6 & 12.4 & 97.9 & 2.1 & 87.1 \\
\hline South Asia, Iran, Afghanistan & 52 & 93.7 & 6.3 & 98.2 & 1.8 & 93.5 \\
\hline South Asia, Iran, Afghanistan & 53 & 86.9 & 13.1 & 92.3 & 7.7 & 85.5 \\
\hline Mongolia & 54 & 0.0 & 100.0 & 0.0 & 100.0 & 0.0 \\
\hline Mongolia & 55 & 100.0 & 0.0 & 100.0 & 0.0 & 100.0 \\
\hline Mongolia & 56 & 73.3 & 26.7 & 91.7 & 8.3 & 97.5 \\
\hline Mongolia & 57 & 54.5 & 45.5 & 75.0 & 25.0 & 96.5 \\
\hline China & 58 & 83.3 & 16.7 & 84.2 & 15.8 & 91.6 \\
\hline China & 59 & 65.0 & 35.0 & 81.3 & 18.8 & 97.7 \\
\hline China & 60 & 28.6 & 71.4 & 100.0 & 0.0 & 97.1 \\
\hline South East Asia & 61 & 83.3 & 16.7 & 80.0 & 20.0 & 85.6 \\
\hline South East Asia & 62 & 73.2 & 26.8 & 85.4 & 14.6 & 91.2 \\
\hline South East Asia & 63 & 67.2 & 32.8 & 69.2 & 30.8 & 83.2 \\
\hline South East Asia & 64 & 97.2 & 2.8 & 72.6 & 27.4 & 88.8 \\
\hline South East Asia & 65 & 87.3 & 12.8 & 76.7 & 23.3 & 84.0 \\
\hline South East Asia & 66 & 83.3 & 16.7 & 58.8 & 41.2 & 96.4 \\
\hline South East Asia & 67 & 73.7 & 26.3 & 85.7 & 14.3 & 91.2 \\
\hline Australia & 68 & 98.8 & 1.3 & 79.0 & 21.0 & 97.6 \\
\hline New Zealand & 69 & 92.3 & 7.7 & 87.8 & 12.2 & 96.8 \\
\hline New Zealand & 70 & 91.4 & 8.6 & 80.4 & 19.6 & 90.0 \\
\hline Russia & 71 & 63.6 & 36.4 & 53.9 & 46.1 & 96.0 \\
\hline Russia & 72 & 80.9 & 19.1 & 75.2 & 24.8 & 76.0 \\
\hline Russia & 73 & 80.8 & 19.2 & 77.8 & 22.2 & 95.6 \\
\hline Russia & 74 & 0.0 & 100.0 & 0.0 & 100.0 & 100.0 \\
\hline
\end{tabular}




\section{Cropland Areas of the World Derived from GCEP3O}

The Landsat-satellite-data-derived global cropland-extent product at 30-m resolution (GCEP30) has numerous applications that vary from producing maps, computing areas, and providing the baseline to derive higher level cropland products such as irrigated versus rainfed cropland, cropping intensities, crop types, and several crop-productivity and crop-water-productivity products (for example, biomass and yield). One of its most important applications is to compute areas of nations, subnations, and much smaller units such as cropland areas of a village. We computed net-cropland areas (NCAs) of various administrative units of the entire world, using pixel counts. Areas also are computed using independent reference data in which case, uncertainty estimates will be required. However, the direct pixelcount approach to area calculations, along with the accuracy error matrices that are based on independent data, is widely recognized as the most reliable. Because this product is produced using Landsat 30-m-resolution ( 1 pixel $=0.09$ ha) data, direct pixel counts is the correct approach for area estimation. In coarseresolution studies such as MODIS 250-m resolution, for example, each pixel is 6.25 ha, and a 1-km-size pixel represents 100 ha. In such situations, areas are best calculated by using subpixelsized areas as actual areas (Thenkabail and others, 2007a) or by using independent reference data. The NCAs include, as per their definition (fig. 1), standing annual crops that are cultivated at least once annually, plus cropland fallows that are equipped for cropping but are not cultivated even once during a year, plus permanent crops such as the plantations; they do not consider cropping intensities.

In this study, the GNCAs of the GCEP30 (fig. 7) were calculated as 1,873,336,858 ha (or 1.873 Bha; table 9), which is about 12.6 percent of the Earth's terrestrial area. Of the 1.873 Bha, the continent areas were Asia, 33 percent; Europe, 25.5 percent; Africa, 16.7 percent; North America, 14.4 percent; South America, 8.1 percent; and Australia and Oceania, 2.4 percent (fig. 12; see also, table 9 ). The cropland-area distributions also are shown by AEZ (fig. 13), in order to visualize AEZs that have varying degrees of cropland.

The GNCAs of nominal-year 2015, calculated using GCEP30, were compared with (1) the global areas (table 10), as reported by MIRCA (updated for year 2015 from data originally in Portmann and others, 2010; also, some additional statistics for year 2015 were from Stefan Siebert [coauthor of Portmann and others, 2010], University of Göttingen, written commun., 2016), and (2) UN FAO for the year 2015 (FAO2015) (FAO, 2019b). The GNCAs, as determined by GCEP30, were higher than MIRCA by 19 percent, and were higher than FAO2015 by 14.4 percent. Both MIRCA and FAO2015 (table 10) were primarily derived from national statistics and some remote sensing or other spatial-data interpolations. In summary, results showed that worldwide cropland areas in GCEP30 for the year 2015 were higher by 236 Mha (14.4 percent), compared to FAO, and 299 Mha (19 percent), compared to MIRCA (table 10). These differences are because of the type of data used, the methods used, the approach to area estimates, and the year for which these estimates were made.



Figure 12. Map showing cropland area (in million hectares [Mha]) by continent, calculated using global cropland-extent product at 30-m resolution (GCEP30) for nominal-year 2015. Also shown are percentages (in parentheses) of cropland area by continent out of total global cropland area, which is 1.873 billion hectares. Continent boundaries from Food and Agricultural Organization of the United Nations (2015). 


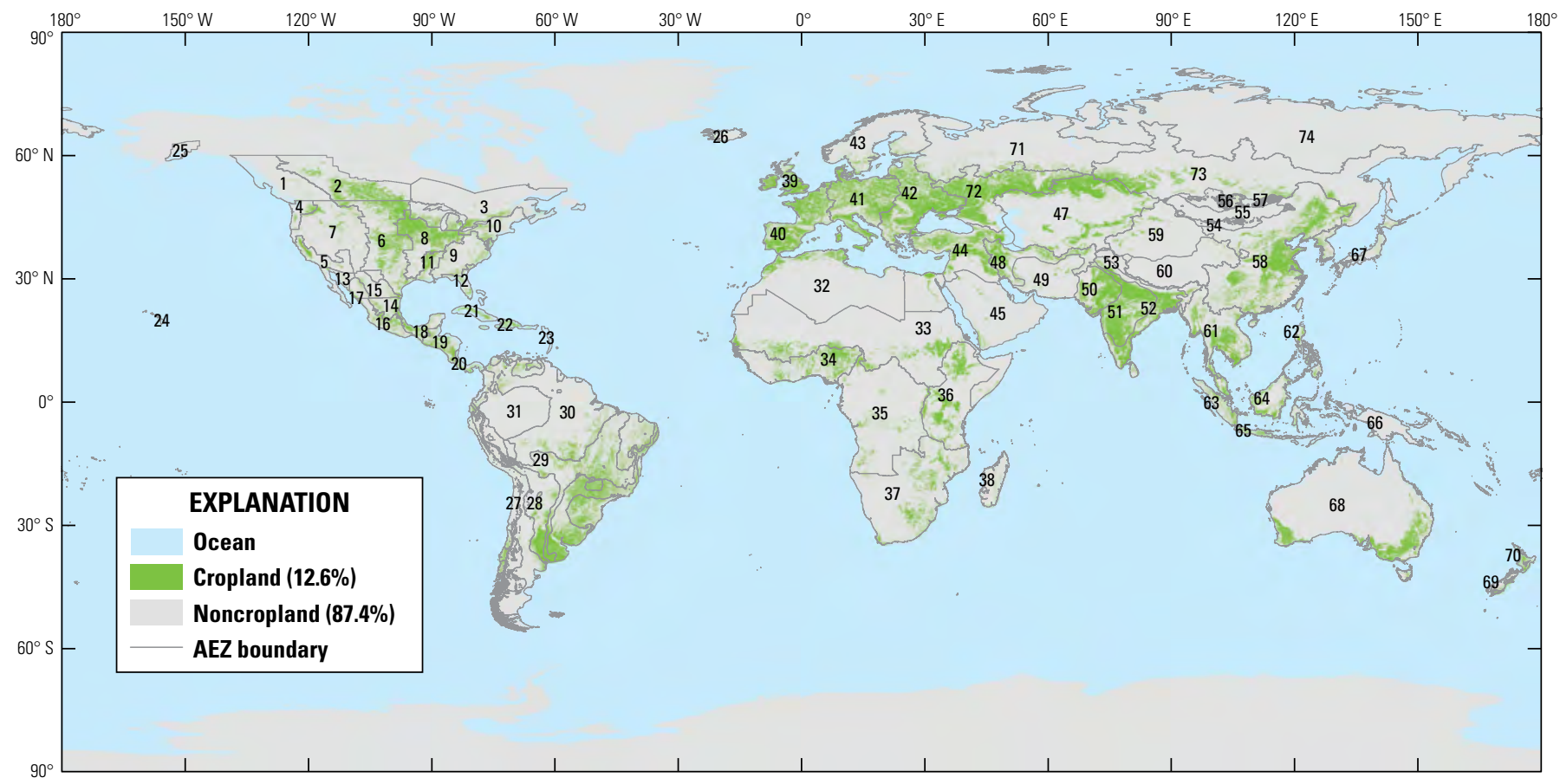

Figure 13. Map showing cropland versus noncropland area by agroecological zone (AEZ), calculated using global cropland-extent product at 30-m resolution (GCEP30) for nominal-year 2015. Also shown are percentages (in parentheses) of cropland and noncropland areas out of total global cropland area, which is 1.873 billion hectares.

Table 9. Cropland areas, by continent, derived from Landsat 30-m-resolution global cropland-extent map for nominal-year 2015.

[Areas are based on pixel-counts. Abbreviations: GCEP30, global cropland-extent product at 30-m resolution; ha, hectare; no., number; SI, item number]

\begin{tabular}{ccllc}
\hline Rank & SI no. & Continent & GCEP30 cropland area (ha) & $\begin{array}{c}\text { Percentage of GCEP30 total global } \\
\text { cropland area (\%) }\end{array}$ \\
\hline 1 & 2 & Asia & $617,512,213$ & 33.0 \\
\hline 2 & 4 & Europe & $477,535,357$ & 25.5 \\
\hline 3 & 1 & Africa & $313,103,091$ & 16.7 \\
\hline 4 & 5 & North America & $269,065,358$ & 14.4 \\
\hline 5 & 6 & South America & $151,996,990$ & 8.1 \\
\hline 6 & 3 & Australia, Oceania & $44,123,848$ & 2.4 \\
\hline Total & & & $1,873,336,858$ & 100.0 \\
\hline
\end{tabular}

${ }^{1}$ From this study. Derived from GCEP30 data for nominal year 2015, except for Argentina, Australia, Brazil, Kazakhstan, and New Zealand. For these five countries, GCEP30 has cropland extent plus managed pastures because these countries have large areas of croplands that are adjacent to, and intermingle with, managed pastures; however, cropland areas reported for all countries (including these five countries) in this table and elsewhere in this report do not include managed pastures. 


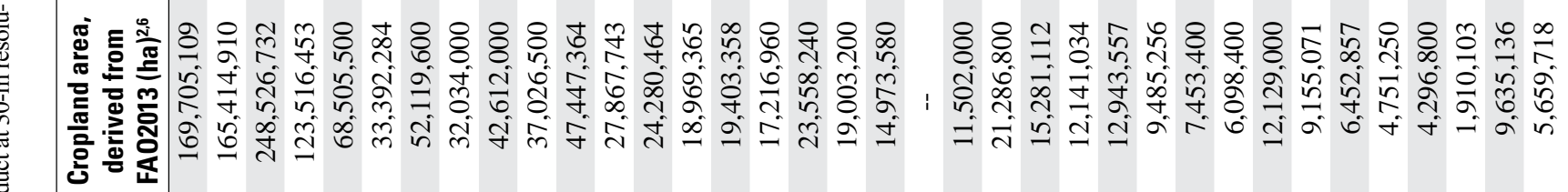

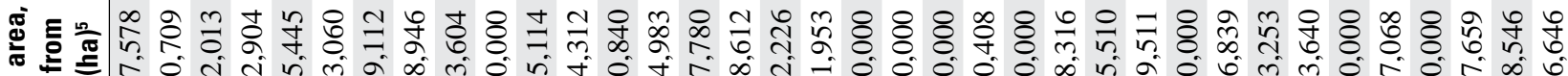

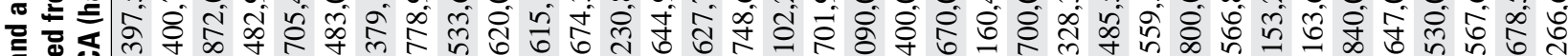

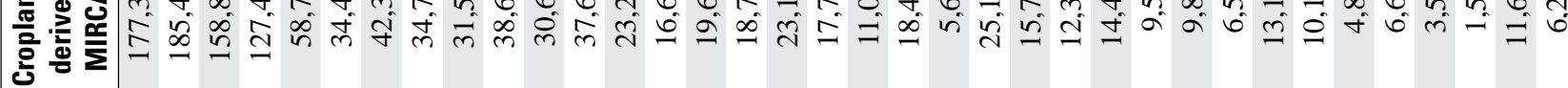



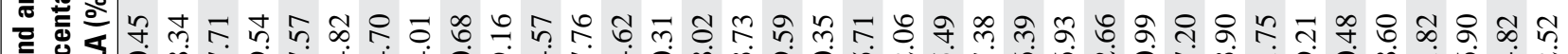
言 흔

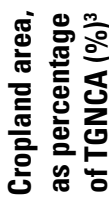

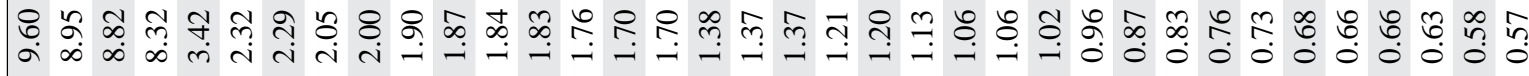

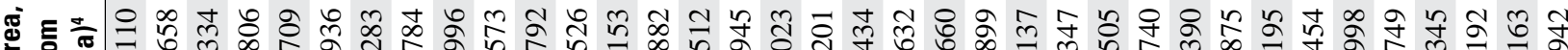

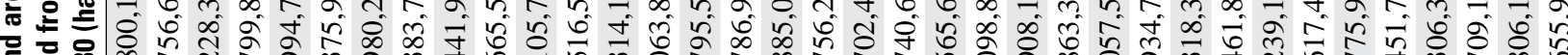

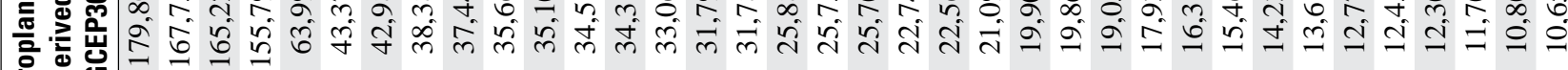
눤

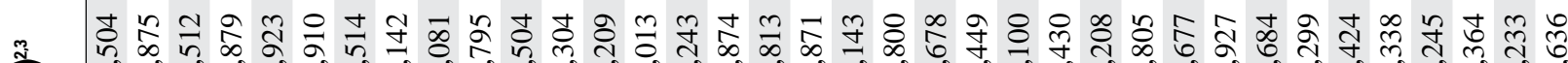
ज की

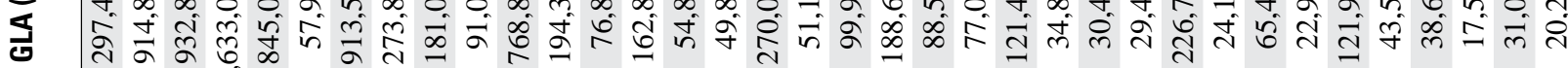


ङु fं

항

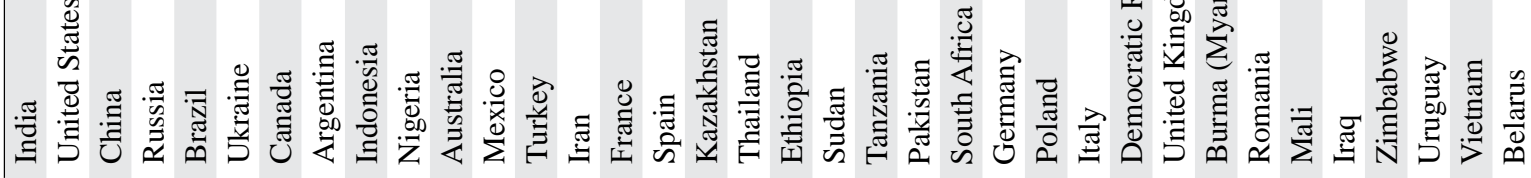

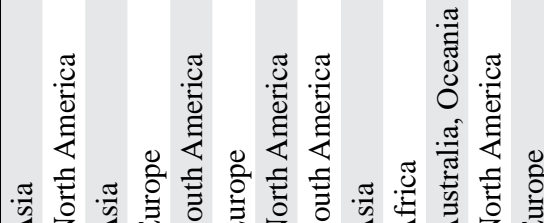

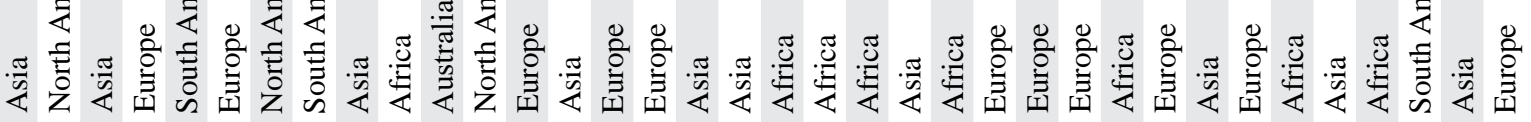

$\neg$ - 



至

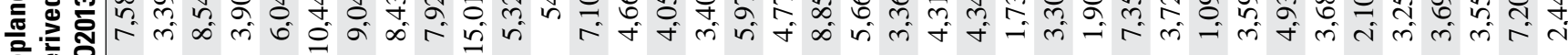
휸 형

๘ँ ๘


원

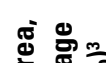

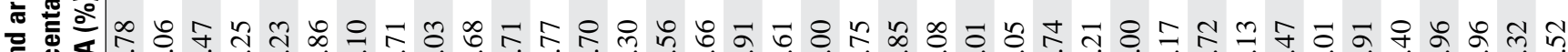

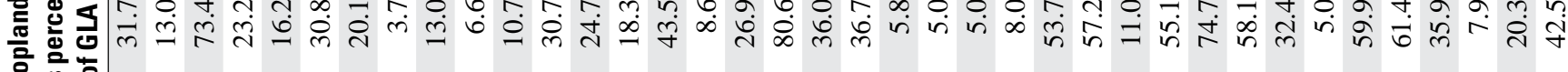
은 은



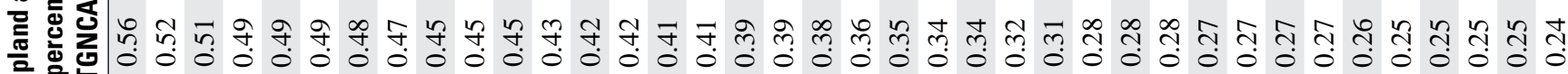

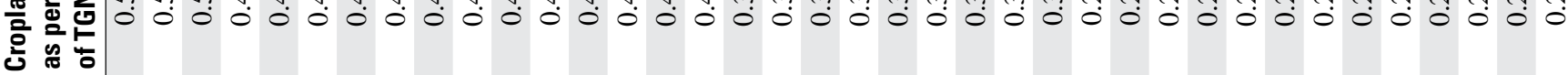

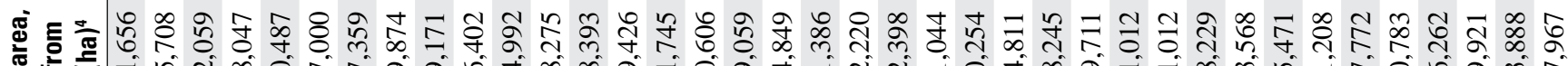

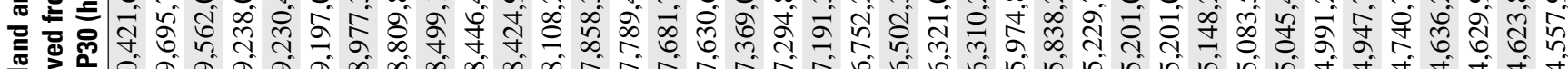

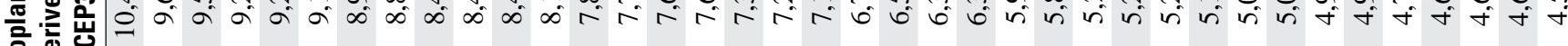
은 웡

霜 可





항

立

迹

产

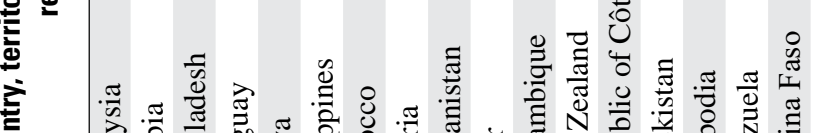

言

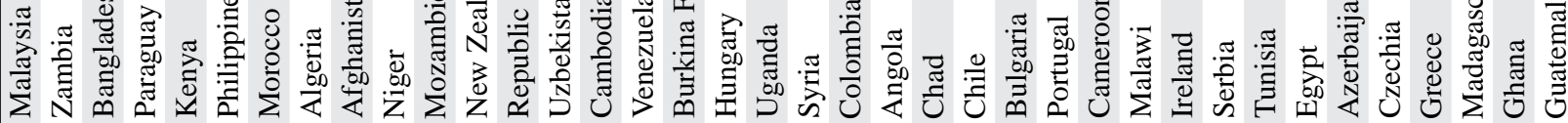





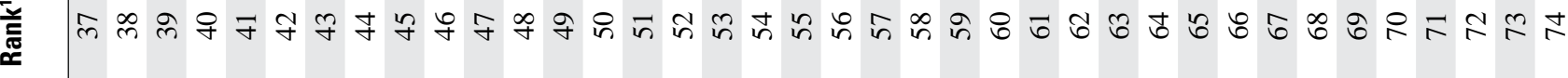




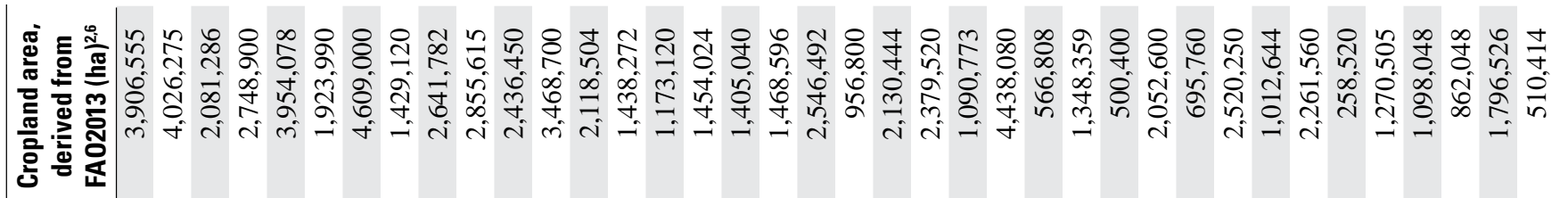

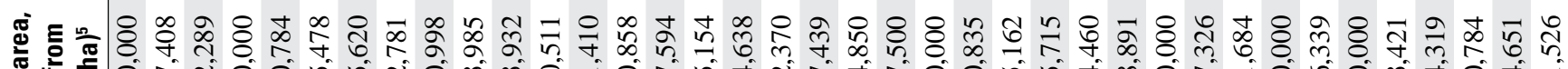








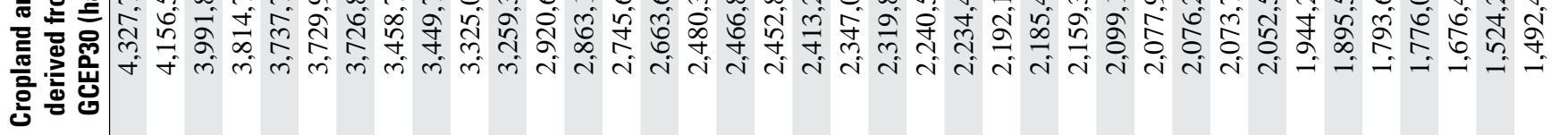
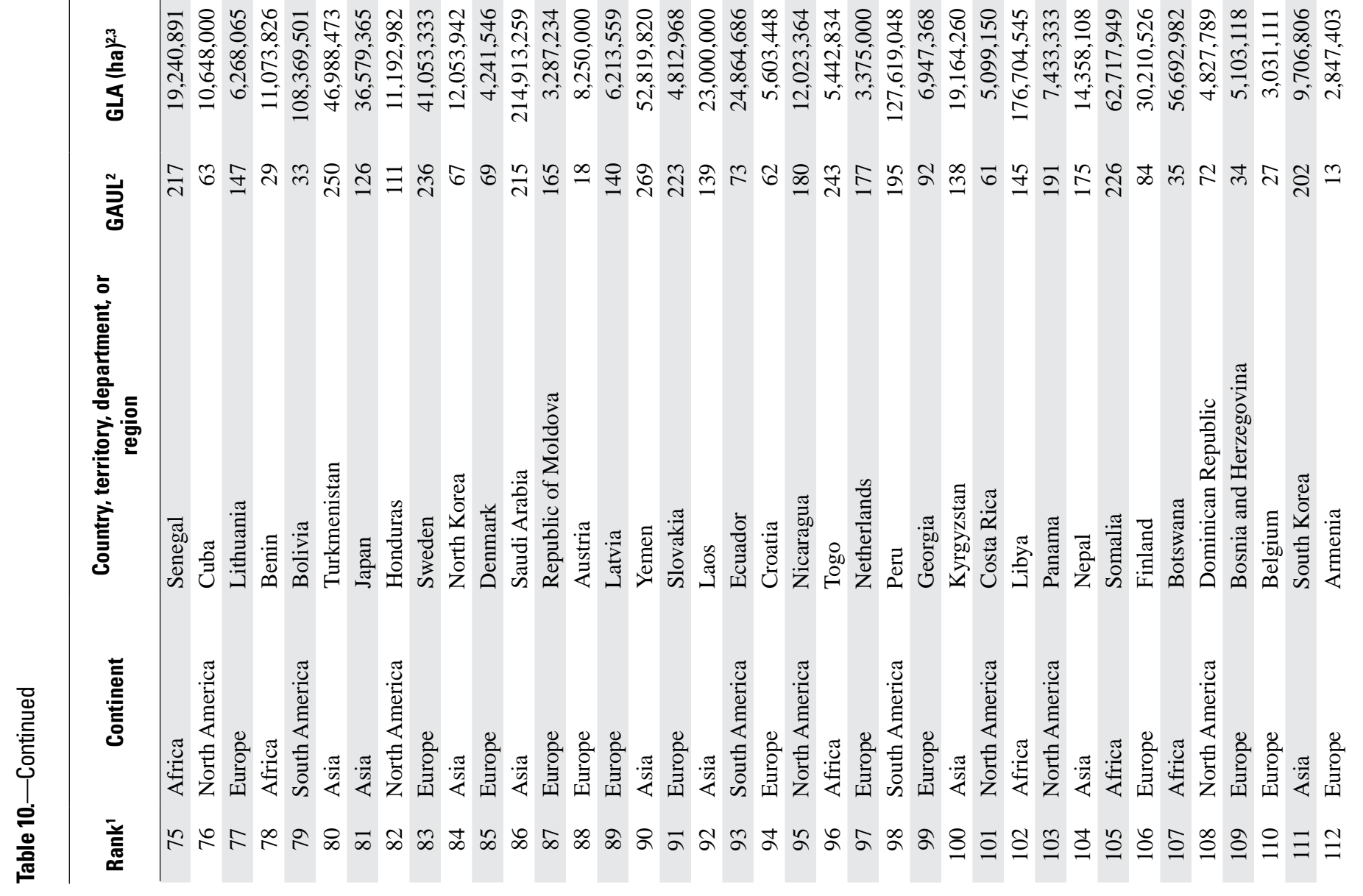


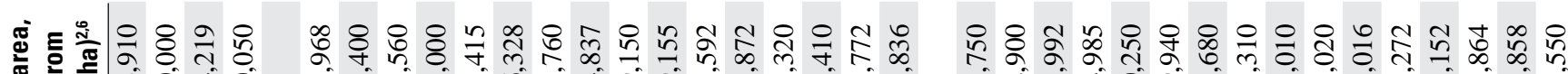

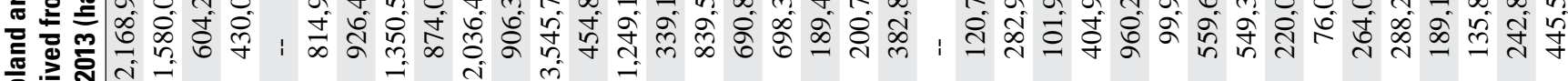





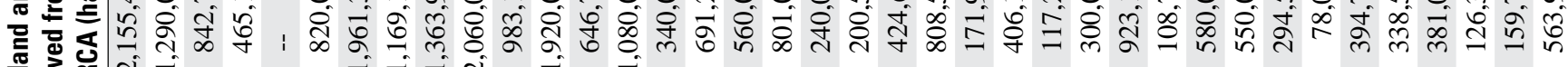

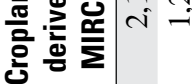

むळ



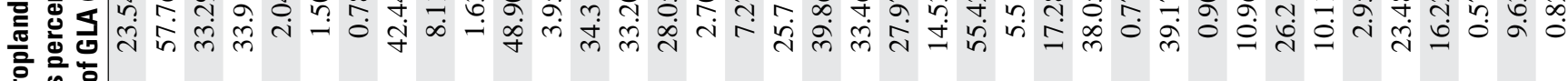
훈 兵



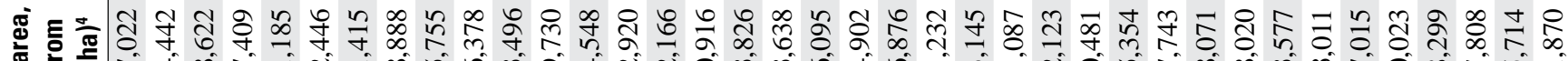

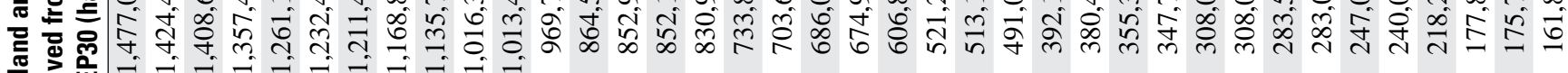
은 릉 岂

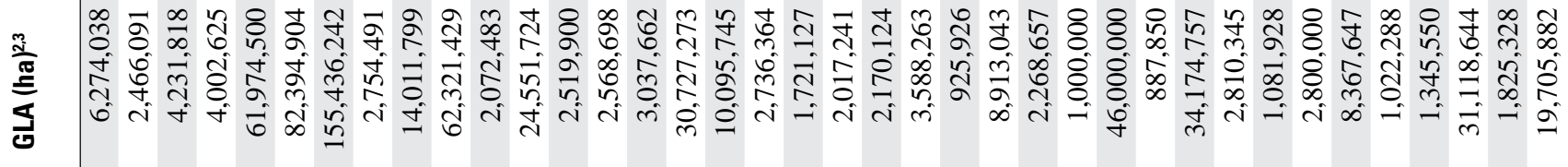

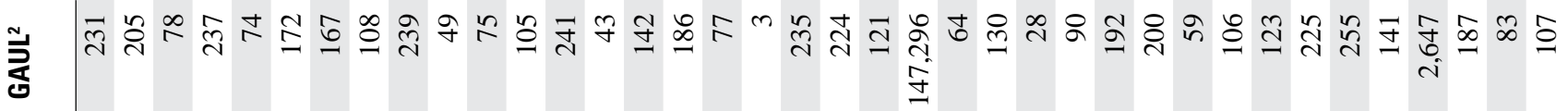
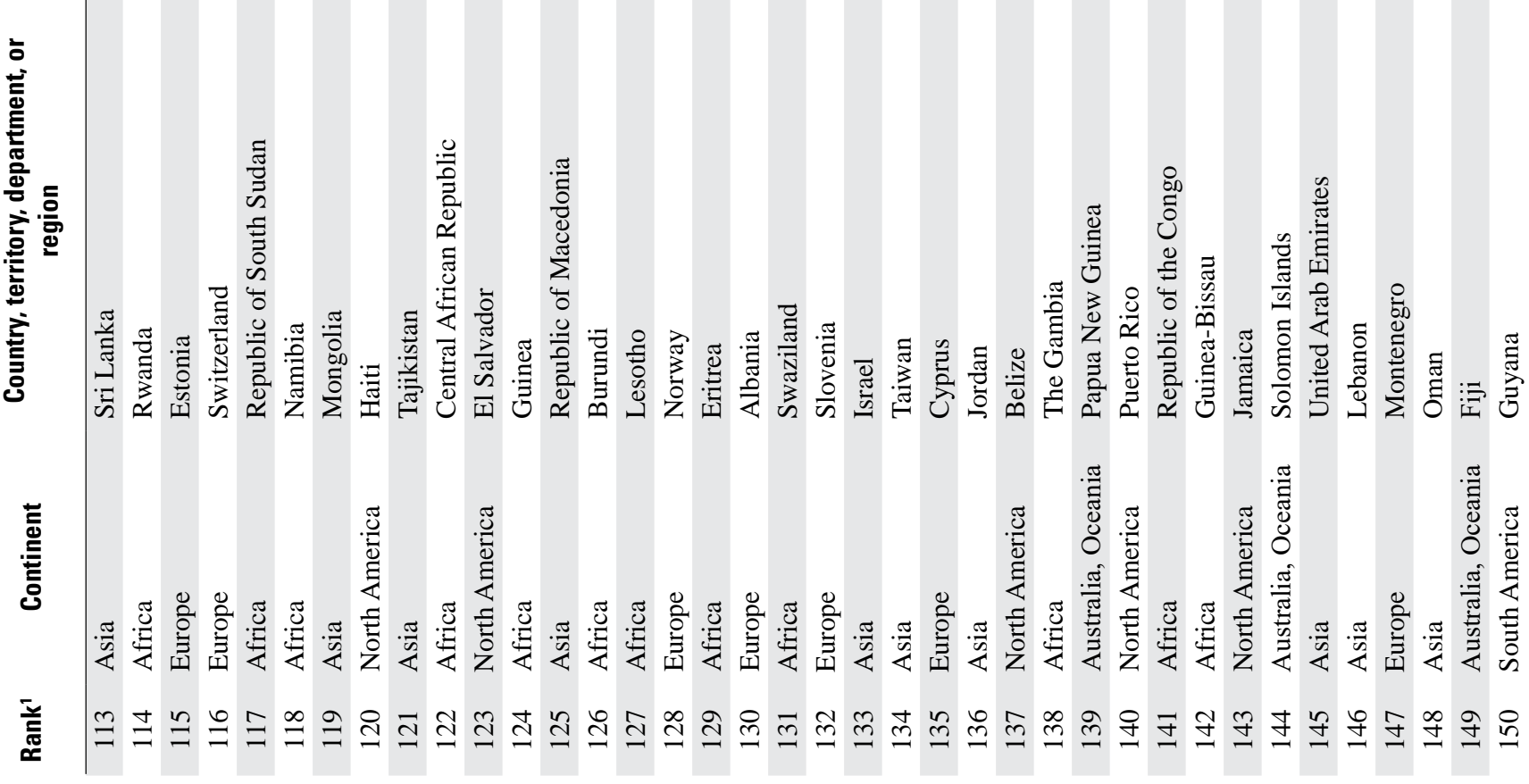

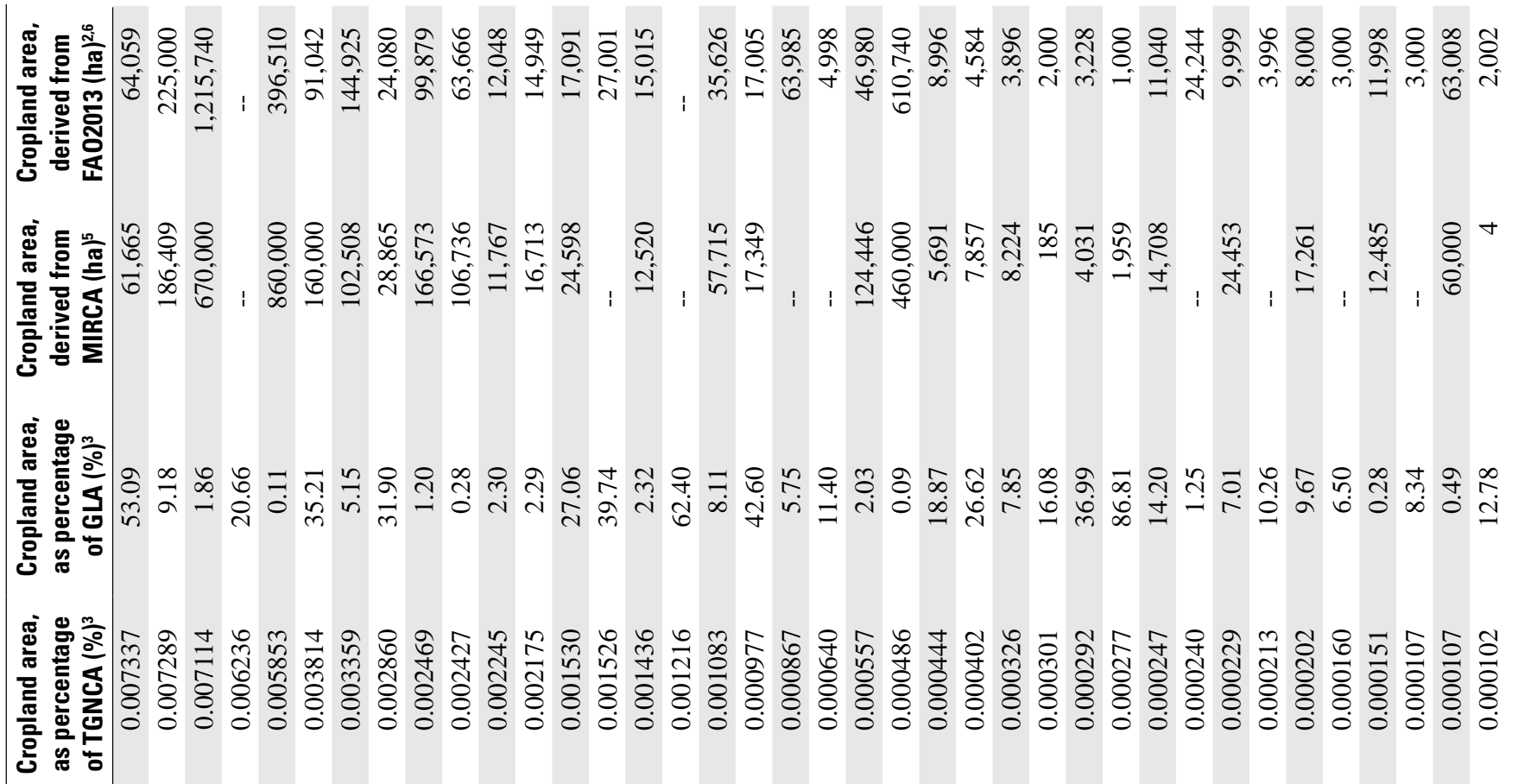

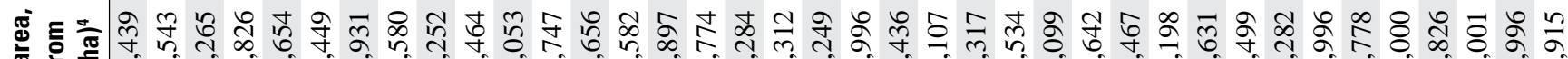


흔

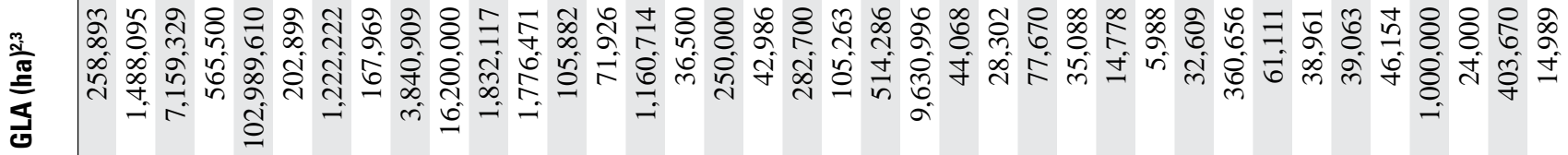

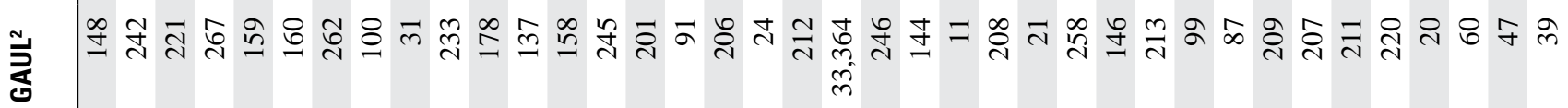
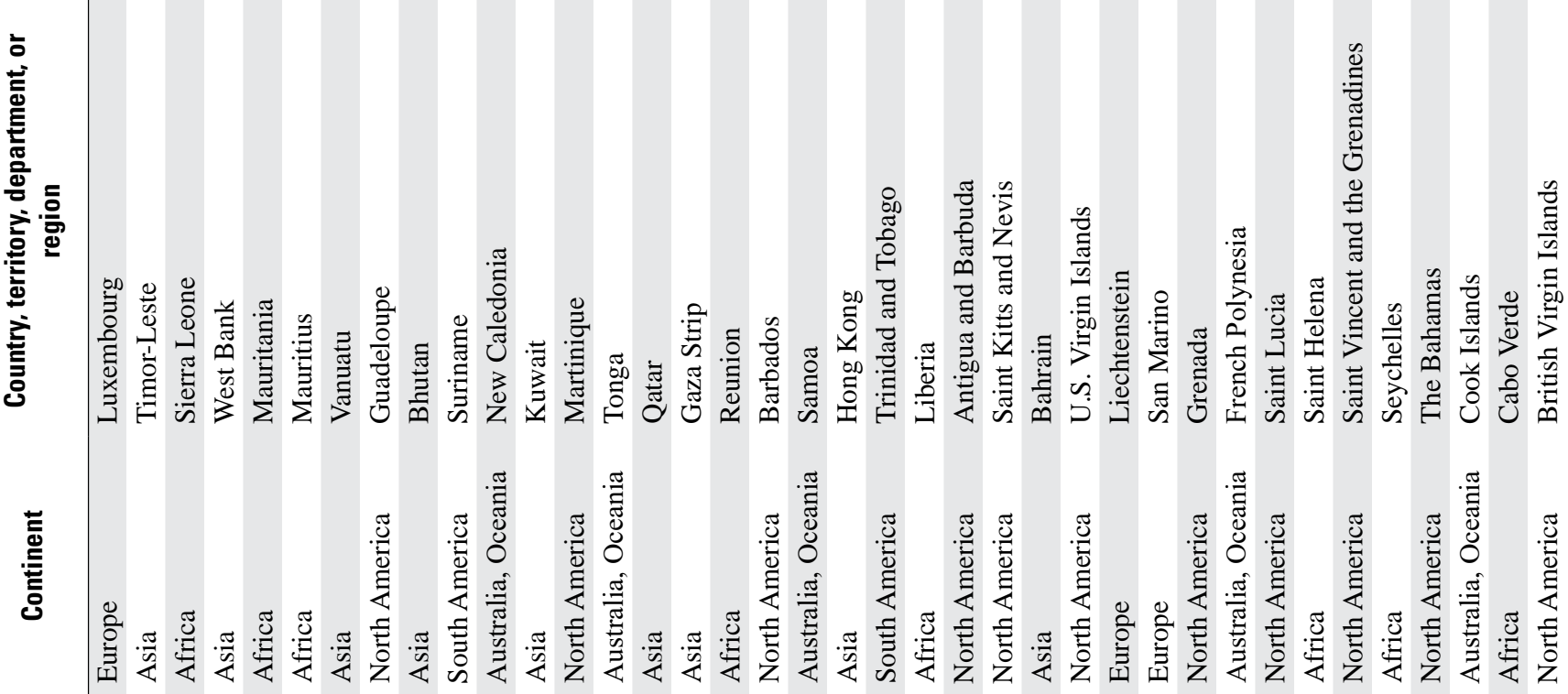

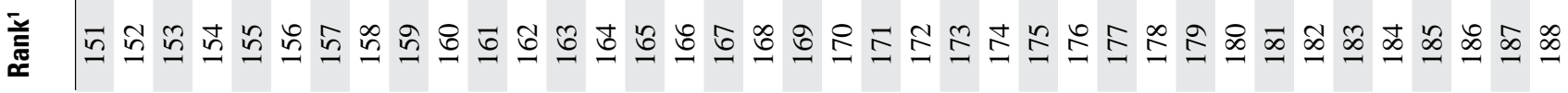





离

\section{흥 응}

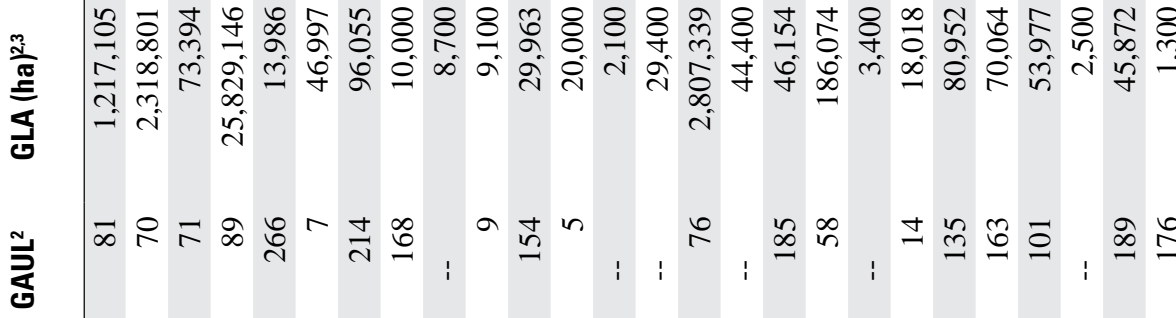
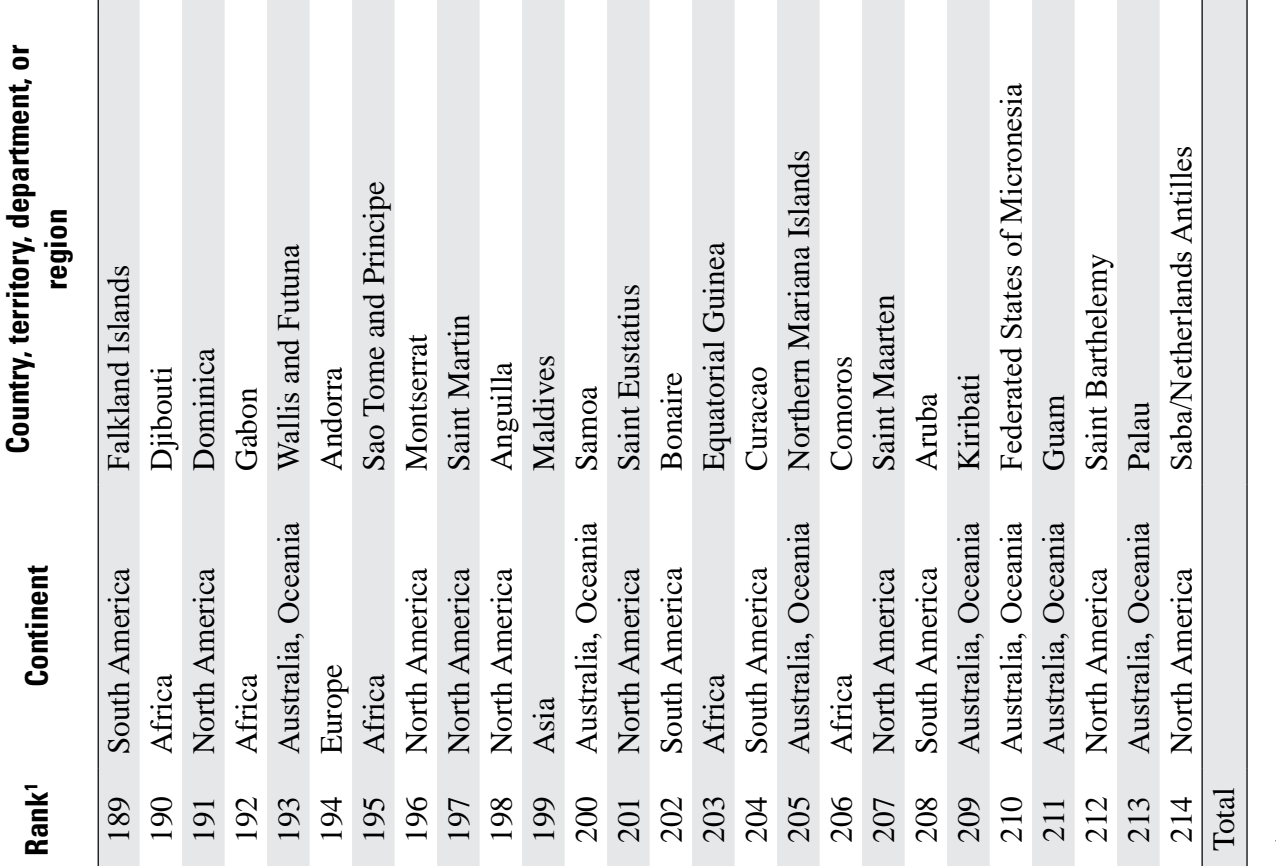
The following are the strengths of the GCEP30 product produced for the nominal-year 2015, compared to the much coarser resolution, nominal-1-km-resolution product GIAM (Thenkabail and others, 2009a, 2011) and GMRCA (Biradar and others, 2009), which were produced for the nominal-year 2000 (fig. 14):

- Capturing missing cropland areas (fig. 14);

- Avoiding the mapping of noncropland as cropland (fig. 14); and

- Capturing fine cropland fractions (fig. 14).

\section{Cropland Areas of the Countries, Territories, Departments, and Regions Derived from GCEP30}

Cropland areas of 214 countries, territories, departments, and regions (table 10) were calculated from GCEP30 using the United Nations' global administrative unit layer (GAUL) boundaries (FAO, 2015). The 10 largest countries ${ }^{26}$ in terms of cropland area as a percentage of the total GNCA (1.873 Bha), in

\footnotetext{
${ }^{26}$ In this section and in the sections that follow, the term "country" (or "countries") is used to refer to countries, territories, departments, and regions.
}

order of ranking, were India, 179.8 Mha (9.6 percent); United States, 167.8 Mha (8.95 percent); China, 165.2 Mha (8.82 percent); Russia, 155.8 Mha (8.32 percent); Brazil, 64 Mha (3.42 percent); Ukraine, 43.4 Mha (2.32 percent); Canada, 42.9 Mha (2.29 percent); Argentina, 38.4 Mha (2.05 percent); Indonesia, 37.4 Mha (2 percent); and Nigeria, 35.7 Mha (1.91 percent). These 10 countries have 50 percent (937 Mha) of the GNCAs; four of them (India, United States, China, and Russia) alone encompass 670 Mha (or 36 percent of the GNCA). The distribution of agricultural cropland as a percentage of the GNCA (1.873 Bha) for each country in the world is depicted in figure 15.

A significant proportion of the croplands of India and China have cropping intensities of greater than 1 , and an overwhelming proportion of cropland in the United States and Russia have crops only during one season in a year, mainly as a result of climate limitations; however, cropping intensities are not reported in this study.

An interesting statistic is the extent of cropland in each country as a percentage of their geographic area (table 10); 18 have 60 percent or more of their geographic area that are cropland. Of these 18, three (Republic of Moldova, San Marino, and Hungary) have over 80 percent of their area that are cropland, four (Denmark, Ukraine, Ireland, and Bangladesh) have 70 to 80 percent


C

F
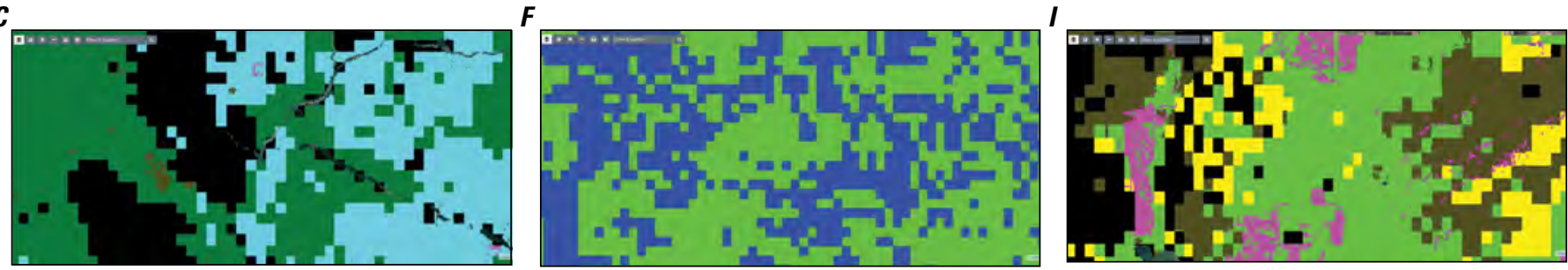

Figure 14. Screen captures of close-up views of cropland areas mapped near $(A, B, C)$ Rio Paraná, Brazil; $(D, E, F)$ Rānchi, India; and $(G, H, I)$ Tashkent, Uzbekistan. $A, D, G$, Unmapped Landsat 30-m-resolution images for reference; white pixels show snowcapped peaks. $B, E, H$, Same areas as $A, D$, and $G$, showing cropland (green shading) mapped from global cropland-extent product at 30-m resolution (GCEP30; see fig. 7) for nominal-year 2015; note that GCEP30 captured missing cropland, separated cropland from noncropland, and clearly mapped cropland fractions. $C, F$, I, Same areas as $A, D$, and $G$, showing cropland (green, blue, brown, yellow and magenta pixels) mapped from coarser resolution (1 km) GIAM/GMRCA product for nominal-year 2000; note that GIAM/GMRCA either missed cropland or mapped significant areas of noncropland as cropland by failing to separate smaller fragments; black pixels show areas where no cropland was mapped. Base map images from Google Earth (used with permission). 


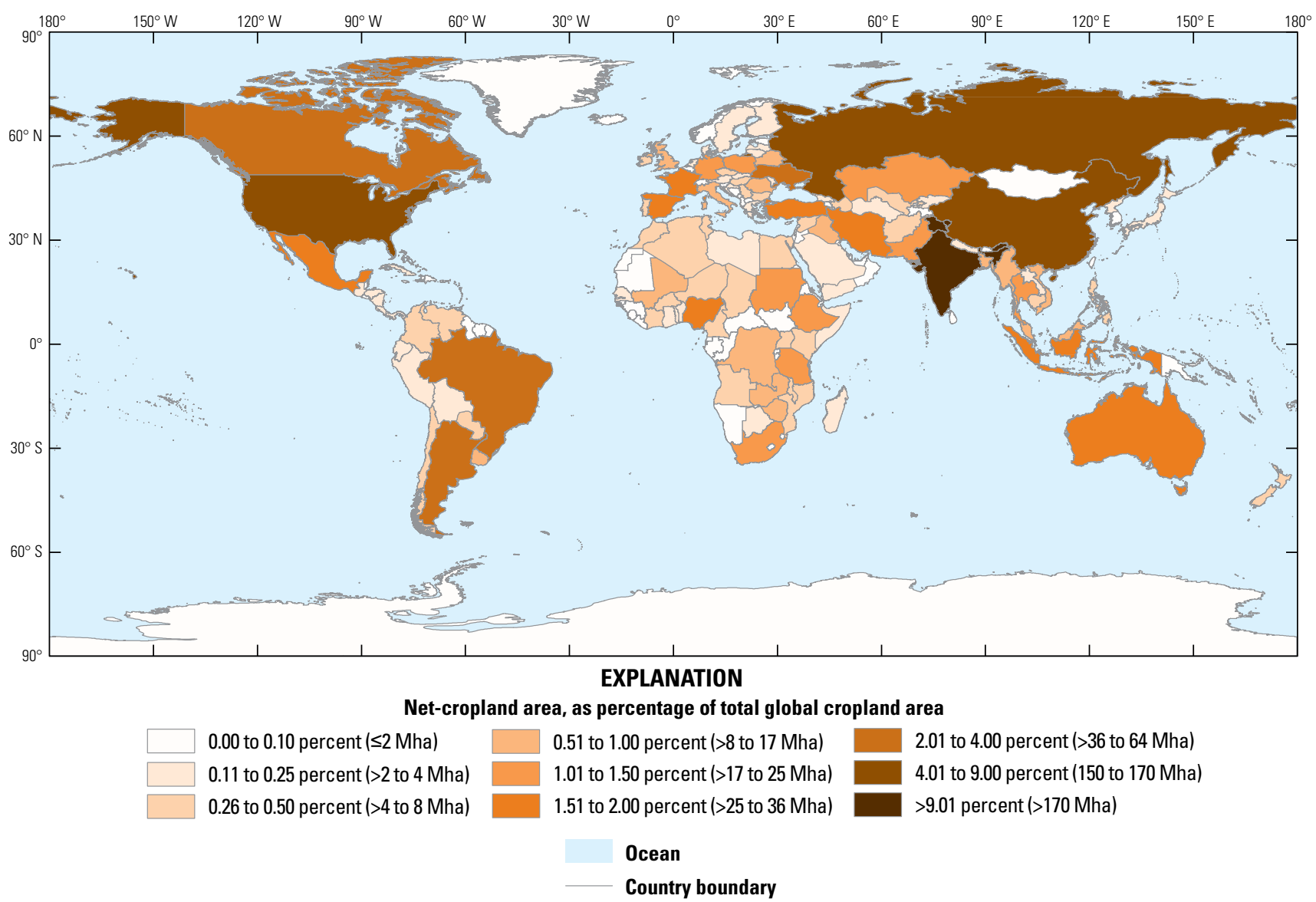

Figure 15. Map showing net-cropland area by country, as percentage of total global net cropland area (GNCA; 1.873 billion hectares), calculated using global cropland-extent product at 30-m resolution (GCEP30) for nominal-year 2015. Also shown are cropland areas (in million hectares [Mha], in parentheses) by country. Note that no countries have cropland areas of between $>64$ and $\leq 150$ Mha. Country boundaries from Food and Agricultural Organization of the United Nations (2015).

that are cropland, and 11 (Uruguay, Netherlands, United Kingdom, Spain, Lithuania, Poland, Gaza Strip, Czechia, Italy, India, and Azerbaijan) have 60 to 70 percent that are cropland. European and South Asian countries can be considered agricultural centers of the world when it comes to the percentage of a country's geographic area that is cropland (fig. 16). Even though countries such as the United States, China, and Russia have high percentages of cropland areas - ranking 2nd, 3rd, and 4th in the world, respectively their croplands as a percentage of their country's geographic area are relatively very low, with 18.3 percent for the United States, 17.7 percent for China, and 9.5 percent for Russia. Most African and South American countries have less than 15 percent of a country's geographic area that are cropland (fig. 16).

The dominant countries in order of ranking for cropland areas in hectares per person are Uruguay ( $3.4 \mathrm{ha} /$ person), Kazakhstan (1.47 ha/person), Australia (1.47 ha/person), Paraguay (1.39 ha/person), Lithuania (1.38 ha/person), Latvia (1.35 ha/person), Canada (1.2 ha/person), Belarus (1.12 ha/person), Ireland (1.1 ha/person), Belize (1.09 ha/person), and Russia (1.09 ha/person) (fig. 17). In comparison, other countries that have large areas of cropland overall but have relatively low areas of cropland per person are United States ( $0.52 \mathrm{ha} /$ person),
France (0.49 ha/person), Germany ( 0.25 ha/person), United Kingdom (0.24 ha/person), India (0.14 ha/person), and China (0.12 ha/person).

\section{Cropland Areas of the Countries, Territories, Departments, and Regions in Different Continents Derived from GCEP30}

Food-security assessments require cropland studies of countries in each continent. Huge disparities exist in cropland extent (fig. 7) and in cropland areas of countries in different continents (tables 11 through 16).

Of the 56 countries in Africa, the six countries that have greater than 5 percent of the total net-cropland area (TNCA) of Africa (313.1 Mha) (table 11) are Nigeria (11.4 percent [of the TNCA of Africa]), Ethiopia (8.2 percent), Sudan (7.3 percent), Tanzania (7.2 percent), South Africa (6.4 percent), and Democratic Republic of the Congo (5.2 percent). However, although cropland areas are very important, other factors also need to be considered when assessing a country's food security. For example, although Egypt has only 1.6 percent of the TNCA of Africa, its croplands 


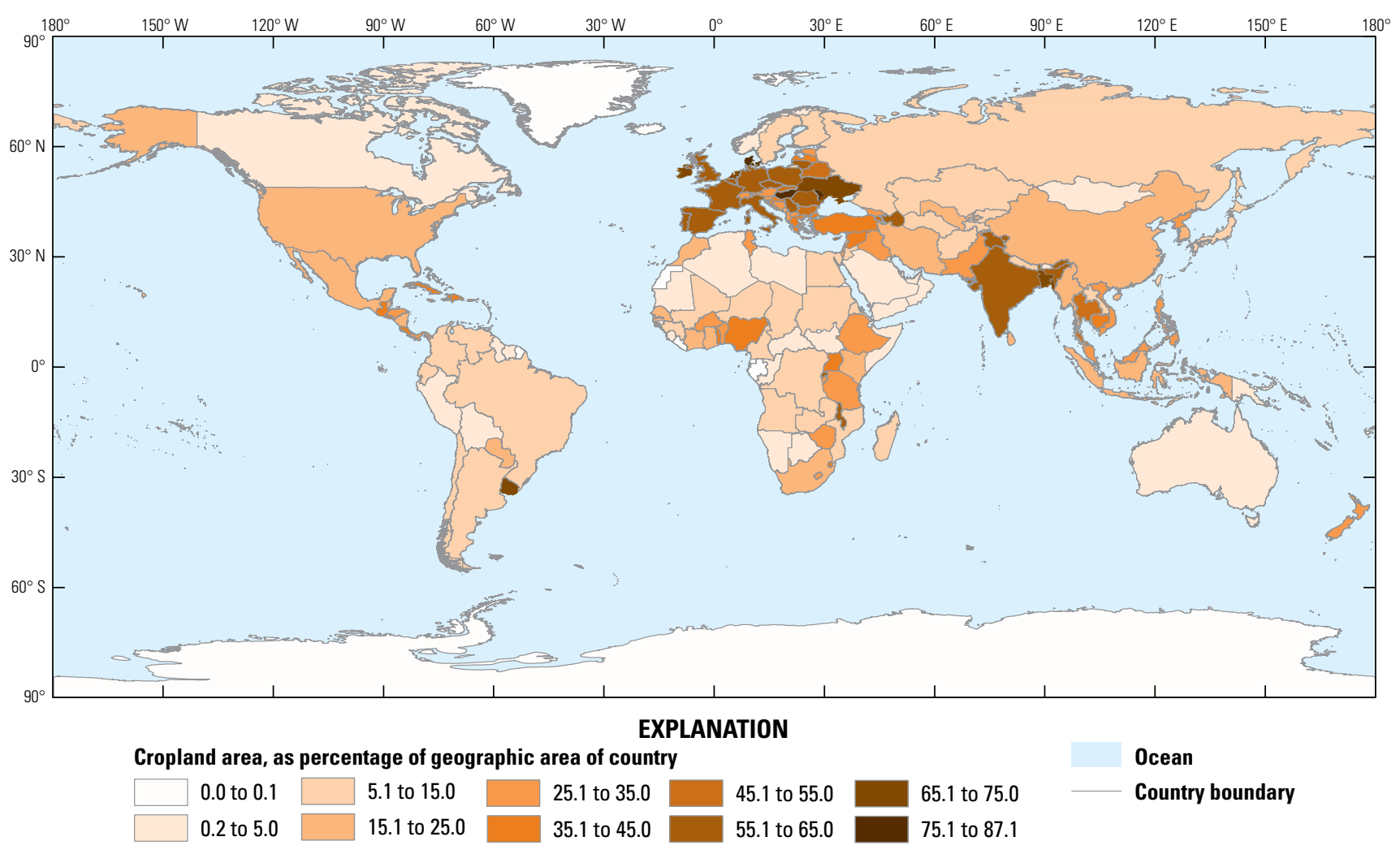

Figure 16. Map showing net-cropland area by country, as percentage of total geographic area of country, calculated using global cropland-extent product at 30-m resolution (GCEP30) for nominal-year 2015. Country boundaries from Food and Agricultural Organization of the United Nations (2015).

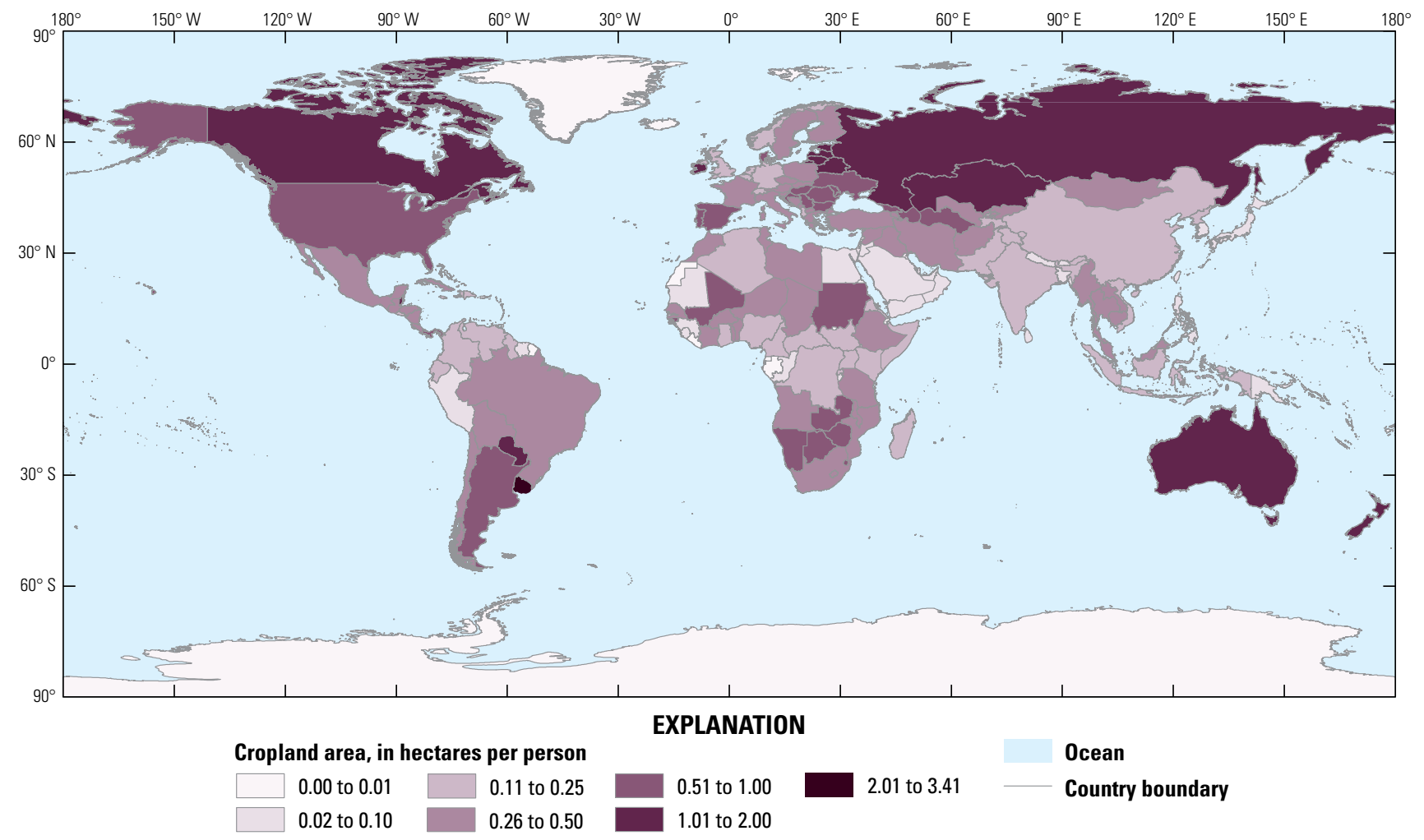

Figure 17. Map showing net-cropland area, in hectares per person, by country, derived using global cropland-extent product at 30-m resolution (GCEP30) for nominal-year 2015. Country boundaries from Food and Agricultural Organization of the United Nations (2015). 
Table 11. Cropland areas for countries, territories, departments, and regions in Africa, derived from Landsat 30-m-resolution global cropland-extent map.

[Abbreviations: FAO, Food and Agricultural Organization of United Nations; GAUL, global administrative unit layer; GCEP30, global cropland-extent product at 30-m resolution; ha, hectare]

\begin{tabular}{|c|c|c|c|c|}
\hline Rank $^{1}$ & GAUL $^{2}$ & Country, territory, department, or region & Cropland area $(\mathrm{ha})^{3}$ & $\begin{array}{c}\text { Cropland area, as percentage of } \\
\text { continent area }(\%)\end{array}$ \\
\hline 1 & 182 & Nigeria & $35,665,573$ & 11.39 \\
\hline 2 & 79 & Ethiopia & $25,702,434$ & 8.21 \\
\hline 4 & 257 & Tanzania & $22,565,660$ & 7.21 \\
\hline 5 & 227 & South Africa & $19,908,137$ & 6.36 \\
\hline 8 & 271 & Zimbabwe & $12,306,345$ & 3.93 \\
\hline 9 & 270 & Zambia & $9,695,708$ & 3.10 \\
\hline 10 & 133 & Kenya & $9,230,487$ & 2.95 \\
\hline 11 & 169 & Morocco & $8,977,359$ & 2.87 \\
\hline 12 & 4 & Algeria & $8,809,874$ & 2.81 \\
\hline 16 & 42 & Burkina Faso & $7,369,059$ & 2.35 \\
\hline 17 & 253 & Uganda & $7,191,386$ & 2.30 \\
\hline 18 & 8 & Angola & $6,321,044$ & 2.02 \\
\hline 19 & 50 & Chad & $6,310,254$ & 2.02 \\
\hline 20 & 45 & Cameroon & $5,201,012$ & 1.66 \\
\hline 21 & 152 & Malawi & $5,201,012$ & 1.66 \\
\hline 22 & 248 & Tunisia & $5,045,471$ & 1.61 \\
\hline 23 & 40,765 & Egypt & $4,991,208$ & 1.59 \\
\hline 24 & 150 & Madagascar & $4,629,921$ & 1.48 \\
\hline 25 & 94 & Ghana & $4,623,888$ & 1.48 \\
\hline 33 & 74 & Republic of South Sudan & $1,261,185$ & 0.40 \\
\hline 34 & 172 & Namibia & $1,232,446$ & 0.39 \\
\hline 35 & 49 & Central African Republic & $1,016,378$ & 0.32 \\
\hline 36 & 105 & Guinea & 969,730 & 0.31 \\
\hline 37 & 43 & Burundi & 852,920 & 0.27 \\
\hline 38 & 142 & Lesotho & 852,166 & 0.27 \\
\hline 39 & 77 & Eritrea & 733,826 & 0.23 \\
\hline 40 & 235 & Swaziland & 686,095 & 0.22 \\
\hline 41 & 90 & The Gambia & 380,481 & 0.12 \\
\hline 42 & 59 & Republic of the Congo & 308,071 & 0.10 \\
\hline 43 & 106 & Guinea-Bissau & 308,020 & 0.10 \\
\hline 44 & 221 & Sierra Leone & 133,265 & 0.04 \\
\hline 45 & 159 & Mauritania & 109,654 & 0.04 \\
\hline 46 & 160 & Mauritius & 71,449 & 0.02 \\
\hline 47 & 206 & Reunion & 20,284 & 0.01 \\
\hline 48 & 144 & Liberia & 9,107 & 0.00 \\
\hline 49 & 207 & Saint Helena & 3,996 & 0.00 \\
\hline
\end{tabular}


Table 11.-Continued

\begin{tabular}{|c|c|c|c|c|}
\hline Rank $^{1}$ & GAUL ${ }^{2}$ & Country, territory, department, or region & Cropland area (ha) ${ }^{3}$ & $\begin{array}{c}\text { Cropland area, as percentage of } \\
\text { continent area }(\%)\end{array}$ \\
\hline 50 & 220 & Seychelles & 3,000 & 0.00 \\
\hline 51 & 47 & Cabo Verde & 1,996 & 0.00 \\
\hline 53 & 89 & Gabon & 1,654 & 0.00 \\
\hline 54 & 214 & Sao Tome and Principe & 1,055 & 0.00 \\
\hline Total & & & $313,103,091$ & 100.00 \\
\hline
\end{tabular}

${ }^{1}$ Ranked by cropland area (as derived from global cropland-extent product at 30-m resolution [GCEP30] data).

${ }^{2}$ From Food and Agricultural Organization of the United Nations (2015).

${ }^{3}$ From this study. Derived from GCEP30 data for nominal year 2015, except for Argentina, Australia, Brazil, Kazakhstan, and New Zealand. For these five countries, GCEP30 has cropland extent plus managed pastures because these countries have large areas of croplands that are adjacent to, and intermingle with, managed pastures; however, cropland areas reported for all countries (including these five countries) in this table and elsewhere in this report do not include managed pastures.

are located in the Nile Delta, which has rich soils and is heavily irrigated by the Aswan Dam throughout the year, and it has grown crops throughout the year (1-3 crops per year), leading to high levels of productivity. On the other hand, Ethiopia has 8.2 percent of the TNCA of Africa, but its cropland areas are primarily rainfed, have poorer soils, and have lower productivity.

Of the 46 countries in Asia, the four countries that have greater than 5 percent of the TNCA of Asia (617.5 Mha) (table 12) are India (29.1 percent [of the TNCA of Asia]), China (26.8 percent), Indonesia (6.1 percent), and Iran (5.4 percent). India and China together have 56 percent of Asia's croplands, and they also are the world's largest countries in terms of irrigated areas and, hence, have higher crop productivity and also intensity. Asia as a whole also is highly irrigated (Thenkabail and others, 2009a, b, 2011). Although some countries have low cropland areas, such as
Pakistan (3.4 percent), Iraq (2 percent), and certain Central Asian countries (Kazakhstan, Kyrgyzstan, Tajikistan, Turkmenistan, and Uzbekistan) (table 12), all of them have extensive irrigation, allowing them double or triple cropping in a year and relatively high productivity. Food-security assessments need to consider these factors as well, and so further work is needed to establish other products such as irrigated versus rainfed, cropping intensity, crop types, cropland fallows, and crop productivity (Estel and others, 2015; Conrad and others, 2016).

Of the 17 countries of Australia and Oceania, which together contain 44.1 Mha of croplands, 98 percent are in Australia and New Zealand (79.6 and 18.4 percent, respectively) alone (table 13). These countries have an equal proportion of pastureland and rangeland (that is, area not mapped as cropland) (Teluguntla and others, 2017b).

Table 12. Cropland areas for countries, territories, departments, and regions in Asia, derived from Landsat 30-m-resolution global cropland-extent map.

[Abbreviations: FAO, Food and Agricultural Organization of United Nations; GAUL, global administrative unit layer; GCEP30, global cropland-extent product at 30-m resolution; ha, hectare]

\begin{tabular}{rrlrc}
\hline Rank $^{\mathbf{1}}$ & GAUL & Country, territory, department, or region & Cropland area (ha) & $\begin{array}{c}\text { Cropland area, as percentage of } \\
\text { continent area (\%) }\end{array}$ \\
\hline 1 & 115 & India & $179,800,110$ & 29.12 \\
\hline 2 & 147,295 & China & $165,228,334$ & 26.76 \\
\hline 3 & 116 & Indonesia & $37,441,996$ & 6.06 \\
\hline 4 & 117 & Iran & $33,063,882$ & 5.35 \\
\hline 5 & 132 & Kazakhstan & $25,885,023$ & 4.19 \\
\hline 6 & 240 & Thailand & $25,756,201$ & 4.17 \\
\hline 7 & 188 & Pakistan & $21,098,899$ & 3.42 \\
\hline 8 & 171 & Burma (Myanmar) & $14,239,195$ & 2.31 \\
\hline 10 & 118 & Iraq & $12,451,749$ & 2.02 \\
\end{tabular}


Table 12.-Continued

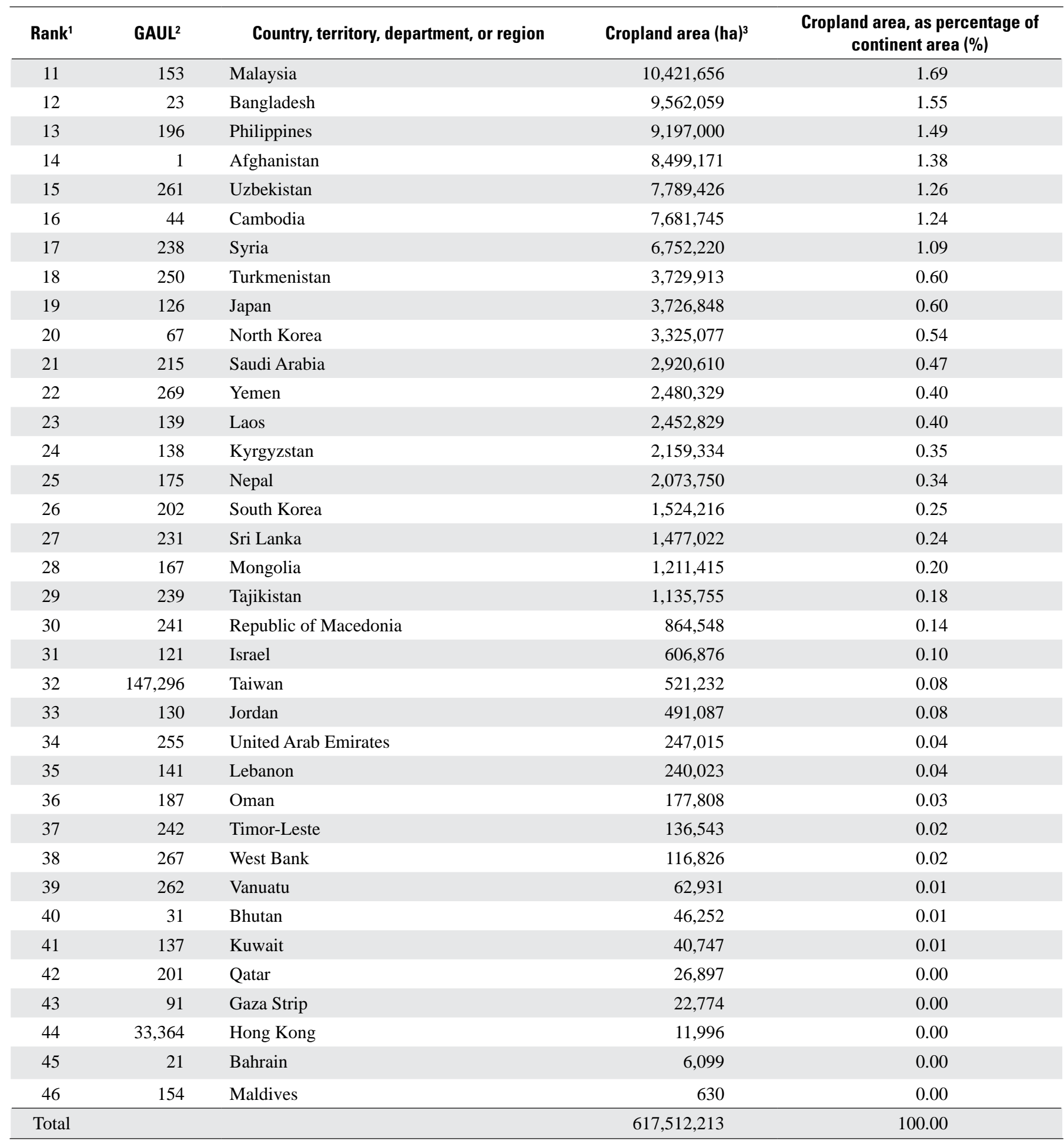

${ }^{1}$ Ranked by cropland area (as derived from global cropland-extent product at 30-m resolution [GCEP30] data).

${ }^{2}$ From Food and Agricultural Organization of the United Nations (2015).

${ }^{3}$ From this study. Derived from GCEP30 data for nominal year 2015, except for Argentina, Australia, Brazil, Kazakhstan, and New Zealand. For these five countries, GCEP30 has cropland extent plus managed pastures because these countries have large areas of croplands that are adjacent to, and intermingle with, managed pastures; however, cropland areas reported for all countries (including these five countries) in this table and elsewhere in this report do not include managed pastures. 
Table 13. Cropland areas for countries, territories, departments, and regions in Australia and Oceania, derived from Landsat 30-m-resolution global cropland-extent map.

[Abbreviations: FAO, Food and Agricultural Organization of United Nation; GAUL, global administrative unit layer; GCEP30, global cropland-extent product at 30-m resolution; ha, hectare]

\begin{tabular}{|c|c|c|c|c|}
\hline Rank $^{1}$ & GAUL $^{2}$ & Country, territory, department, or region & Cropland area $(\mathrm{ha})^{3}$ & $\begin{array}{c}\text { Cropland area, as percentage of } \\
\text { continent area (\%) }\end{array}$ \\
\hline 1 & 17 & Australia & $35,105,792$ & 79.56 \\
\hline 2 & 179 & New Zealand & $8,108,275$ & 18.38 \\
\hline 3 & 192 & Papua New Guinea & 355,354 & 0.81 \\
\hline 4 & 225 & Solomon Islands & 283,011 & 0.64 \\
\hline 5 & 83 & Fiji & 175,714 & 0.40 \\
\hline 6 & 178 & New Caledonia & 42,053 & 0.10 \\
\hline 7 & 245 & Tonga & 28,582 & 0.06 \\
\hline 8 & 212 & Samoa & 16,249 & 0.04 \\
\hline 9 & 87 & French Polynesia & 4,499 & 0.01 \\
\hline 10 & 60 & Cook Islands & 2,001 & 0.00 \\
\hline 11 & 266 & Wallis and Futuna & 1,487 & 0.00 \\
\hline 12 & 5 & American Samoa & 374 & 0.00 \\
\hline 13 & 185 & Northern Mariana Islands & 198 & 0.00 \\
\hline 14 & 135 & Kiribati & 87 & 0.00 \\
\hline 15 & 163 & Federated States of Micronesia & 65 & 0.00 \\
\hline 16 & 101 & Guam & 63 & 0.00 \\
\hline 17 & 189 & Palau & 44 & 0.00 \\
\hline Total & & & $44,123,848$ & 100.0 \\
\hline
\end{tabular}

${ }^{1}$ Ranked by cropland area (as derived from global cropland-extent product at 30-m resolution [GCEP30] data).

${ }^{2}$ From Food and Agricultural Organization of the United Nations (2015).

${ }^{3}$ From this study. Derived from GCEP30 data for nominal year 2015, except for Argentina, Australia, Brazil, Kazakhstan, and New Zealand. For these five countries, GCEP30 has cropland extent plus managed pastures because these countries have large areas of croplands that are adjacent to, and intermingle with, managed pastures; however, cropland areas reported for all countries (including these five countries) in this table and elsewhere in this report do not include managed pastures.

Of the 17 South American countries, which together contain 152 Mha of croplands, Brazil (42.1 percent) and Argentina (25.3 percent) together have 67.4 percent of croplands (table 14). An overwhelming proportion of these are rainfed cropland (Biradar and others, 2009).

Of the 44 European countries, which together contain 477 Mha of croplands, the five countries that have more than 5 percent of the continent as cropland areas (table 15) are Russia (32.6 percent), Ukraine (9.1 percent), Turkey (7.2 percent), France (6.7 percent), and
Spain (6.7 percent). Together they have 62.3 percent of cropland (table 13).

Of the 34 North American countries, which together contain 269 Mha of croplands, the three that contain 91.2 percent of all cropland (table 15) are United States (62.4 percent), Canada (16.0 percent), and Mexico (12.8 percent) (table 16). Both United States and Canada are the world's major producers of food, an overwhelming proportion of which comes from highly productive, technologically advanced, rainfed cropland (Biradar and others, 2009; Thenkabail and others, 2009a, 2011).

Table 14. Cropland areas for countries, territories, departments, and regions in South America, derived from Landsat 30-m-resolution global cropland-extent map.

[Abbreviations: FAO, Food and Agricultural Organization of United Nations; GAUL, global administrative unit layer; GCEP30, global cropland-extent product at 30-m resolution; ha, hectare; --, no GAUL number assigned]

\begin{tabular}{cclrr}
\hline Rank & GAUL & Country, territory, department, or region & Cropland area (ha) $)^{\mathbf{3}}$ & $\begin{array}{c}\text { Cropland area, as percentage of } \\
\text { continent area (\%) }\end{array}$ \\
\hline 1 & 37 & Brazil & $63,994,709$ & 42.1 \\
2 & 12 & Argentina & $38,383,784$ & 25.3 \\
\hline 3 & 260 & Uruguay & $11,709,192$ & 7.7 \\
\hline 4 & 194 & Paraguay & $9,238,047$ & 6.1 \\
5 & 263 & Venezuela & $7,630,606$ & 5.0 \\
\hline
\end{tabular}


Table 14.-Continued

\begin{tabular}{rrlrc}
\hline Rank & GAUL & Country, territory, department, or region & Cropland area (ha) & $\begin{array}{c}\text { Cropland area, as percentage of } \\
\text { continent area (\%) }\end{array}$ \\
\hline 6 & 57 & Colombia & $6,502,398$ & 4.3 \\
\hline 7 & 51 & Chile & $5,974,811$ & 3.9 \\
\hline 8 & 33 & Bolivia & $3,737,749$ & 2.5 \\
\hline 9 & 73 & Ecuador & $2,413,259$ & 1.6 \\
10 & 195 & Peru & $2,192,154$ & 1.4 \\
11 & 107 & Guyana & 161,870 & 0.1 \\
12 & 233 & Suriname & 45,464 & 0.0 \\
13 & 246 & Trinidad and Tobago & 10,436 & 0.0 \\
14 & 81 & Falkland Islands & 1,900 & 0.0 \\
15 & -- & Bonaire & 269 & 0.0 \\
16 & -- & Curacao & 244 & 0.0 \\
\hline 17 & 14 & Aruba & 98 & 0.0 \\
\hline Total & & & $151,996,990$ & 100.0 \\
\hline
\end{tabular}

${ }^{1}$ Ranked by cropland area (as derived from global cropland-extent product at 30-m resolution [GCEP30] data).

${ }^{2}$ From Food and Agricultural Organization of the United Nations (2015).

${ }^{3}$ From this study. Derived from GCEP30 data for nominal year 2015, except for Argentina, Australia, Brazil, Kazakhstan, and New Zealand. For these five countries, GCEP30 has cropland extent plus managed pastures because these countries have large areas of croplands that are adjacent to, and intermingle with, managed pastures; however, cropland areas reported for all countries (including these five countries) in this table and elsewhere in this report do not include managed pastures.

Table 15. Cropland areas for countries, territories, departments, and regions in Europe, derived from Landsat 30-m-resolution global cropland-extent map.

[Abbreviations: FAO, Food and Agricultural Organization of United Nations; GAUL, global administrative unit layer; GCEP30, global cropland-extent product at 30-m resolution; ha, hectare]

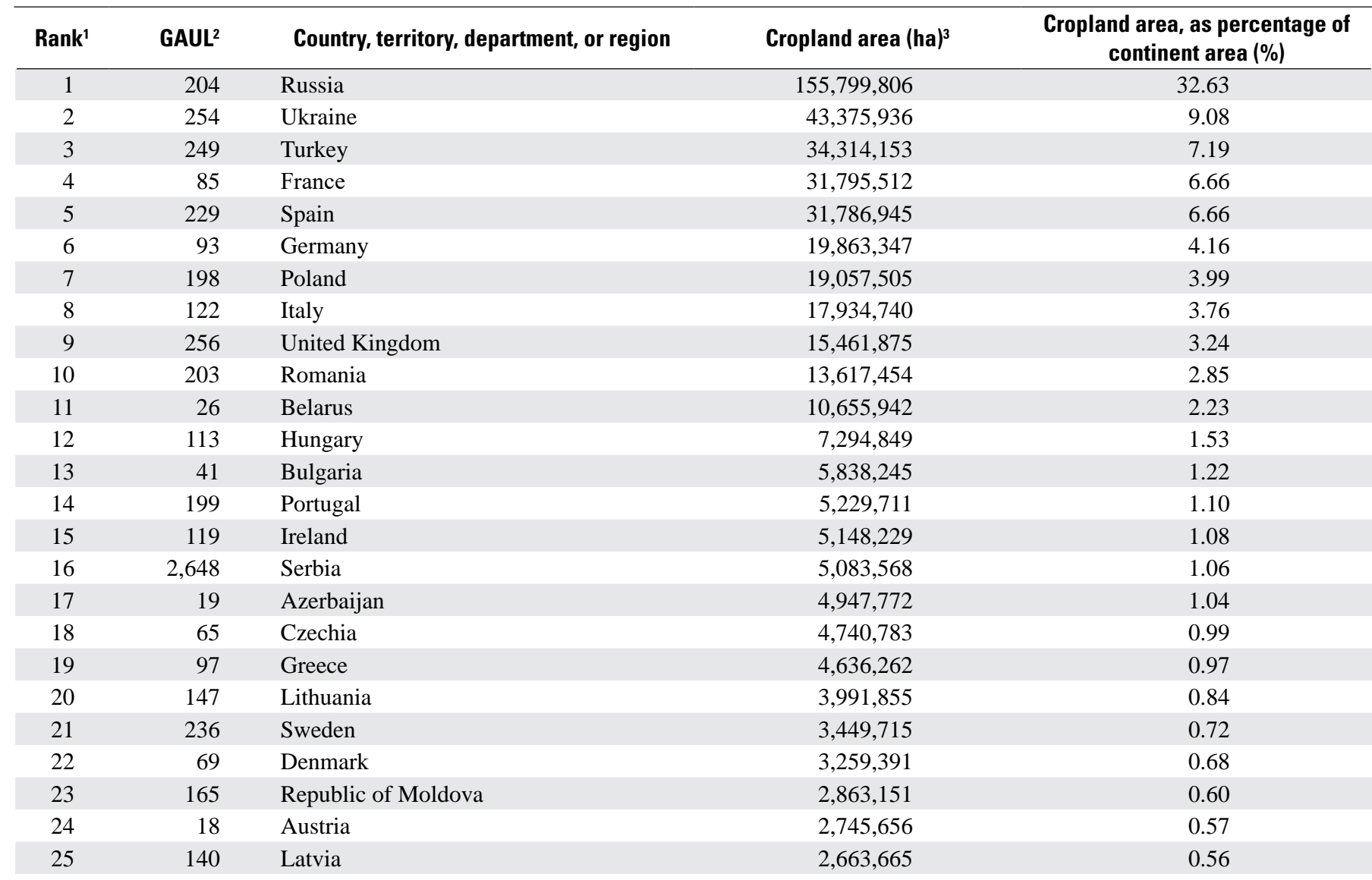


Table 15.-Continued



${ }^{1}$ Ranked by cropland area (as derived from global cropland-extent product at 30-m resolution [GCEP30] data).

${ }^{2}$ From Food and Agricultural Organization of the United Nations (2015).

${ }^{3}$ From this study. Derived from GCEP30 data for nominal year 2015, except for Argentina, Australia, Brazil, Kazakhstan, and New Zealand. For these five countries, GCEP30 has cropland extent plus managed pastures because these countries have large areas of croplands that are adjacent to, and intermingle with, managed pastures; however, cropland areas reported for all countries (including these five countries) in this table and elsewhere in this report do not include managed pastures.

Table 16. Cropland areas for countries, territories, departments, and regions in North America, derived from Landsat 30-m-resolution global cropland-extent map.

[Abbreviations: FAO, Food and Agricultural Organization of United Nations; GAUL, global administrative unit layer; GCEP30, global cropland-extent product at 30-m resolution; ha, hectare; --, no GAUL number assigned]

\begin{tabular}{|c|c|c|c|c|}
\hline $\operatorname{Rank}^{1}$ & GAUL $^{2}$ & Country, territory, department, or region & Cropland area (ha) ${ }^{3}$ & $\begin{array}{c}\text { Cropland area, as percentage of } \\
\text { continent area }(\%)\end{array}$ \\
\hline 1 & 259 & United States & $167,756,658$ & 62.35 \\
\hline 2 & 46 & Canada & $42,980,283$ & 15.97 \\
\hline 4 & 103 & Guatemala & $4,557,967$ & 1.69 \\
\hline 5 & 63 & Cuba & $4,156,564$ & 1.54 \\
\hline 8 & 61 & Costa Rica & $2,099,180$ & 0.78 \\
\hline 9 & 191 & Panama & $2,076,237$ & 0.77 \\
\hline 10 & 72 & Dominican Republic & $1,793,613$ & 0.67 \\
\hline 11 & 108 & Haiti & $1,168,888$ & 0.43 \\
\hline 12 & 75 & El Salvador & $1,013,496$ & 0.38 \\
\hline 16 & 100 & Guadeloupe & 53,580 & 0.02 \\
\hline 17 & 158 & Martinique & 28,656 & 0.01 \\
\hline 18 & 24 & Barbados & 18,312 & 0.01 \\
\hline 19 & 11 & Antigua and Barbuda & 8,317 & 0.00 \\
\hline
\end{tabular}


Table 16.-Continued

\begin{tabular}{cclcc}
\hline Rank & GAUL & Country, territory, department, or region & Cropland area (ha) $)^{\mathbf{3}}$ & $\begin{array}{c}\text { Cropland area, as percentage of } \\
\text { Continent area (\%) }\end{array}$ \\
\hline 20 & 208 & Saint Kitts and Nevis & 7,534 & 0.00 \\
\hline 21 & 258 & U.S. Virgin Islands & 5,642 & 0.00 \\
\hline 22 & 99 & Grenada & 4,631 & 0.00 \\
\hline 23 & 209 & Saint Lucia & 4,282 & 0.00 \\
\hline 24 & 211 & Saint Vincent and the Grenadines & 3,778 & 0.00 \\
\hline 25 & 20 & The Bahamas & 2,826 & 0.00 \\
\hline 26 & 39 & British Virgin Islands & 1,915 & 0.00 \\
\hline 27 & 71 & Dominica & 1,685 & 0.00 \\
\hline 28 & 168 & Montserrat & 855 & 0.00 \\
\hline 29 & -- & Saint Martin & 703 & 0.00 \\
\hline 30 & 9 & Anguilla & 680 & 0.00 \\
\hline 31 & -- & Saint Eustatius & 368 & 0.00 \\
\hline 32 & -- & Saint Maarten & 123 & 0.00 \\
\hline 33 & -- & Saint Barthelemy & 63 & 0.00 \\
\hline 34 & 176 & Saba/Netherlands Antilles & 26 & 0.00 \\
\hline Total & & & $269,065,358$ & 100.00 \\
\hline
\end{tabular}

${ }^{1}$ Ranked by cropland area (as derived from global cropland-extent product at 30-m resolution [GCEP30] data).

${ }^{2}$ From Food and Agricultural Organization of the United Nations (2015).

${ }^{3}$ From this study. Derived from GCEP30 data for nominal year 2015, except for Argentina, Australia, Brazil, Kazakhstan, and New Zealand. For these five countries, GCEP30 has cropland extent plus managed pastures because these countries have large areas of croplands that are adjacent to, and intermingle with, managed pastures; however, cropland areas reported for all countries (including these five countries) in this table and elsewhere in this report do not include managed pastures.

\section{Comparison of GCEP30-Derived Cropland Areas by Continent with Cropland Areas from Other Statistical Sources}

The UN's FAOSTAT (http://www.fao.org/faostat/en/\#data) is the official entity that provides countrywise statistics internationally on food and agriculture. A comparison of countrywise statistics on cropland areas reported in FAOSTAT with that derived from GCEP30 (fig. 18) showed that GCEP30 explained 93 percent of the variability in countrywise cropland data reported by FAOSTAT. In addition, the slope of the predicting line is 0.89 (fig. 18). When all 214 countries are considered, GCEP30 reports 14.4 percent greater areas compared to FAOSTAT (table 10; see also, fig. 18). Similarly, a strong relation exists between GCEP30 and the monthly irrigated and rainfed crop areas for the year 2000 (MIRCA2000) (Monfreda and others, 2008; Portmann and others, 2010; also, some additional statistics for year 2015 were from Stefan Siebert [coauthor of Portmann and others, 2010], University of Göttingen, written commun., 2016), as shown in figure 19 $\left(R^{2}=0.97\right.$; slope $\left.=1.02\right)$. When all 214 countries are considered, GCEP30 reported 19 percent greater cropland areas compared to MIRCA2000 (table 10; fig. 19).

The GCEP30 product also can determine areas of very small subregions. We obtained subnational statistics on states or provinces of a few countries (United States, China, Thailand, Philippines, Indonesia, and South Korea) and compared these statistics with cropland areas derived from GCEP30. A high degree of correlation exists between the two sets of data (fig. 20), with the exception of a few provinces in Indonesia and China where GCEP30 had higher estimates.
Districts of India derived from GCEP30 were compared with national statistics of India (fig. 21). GCEP30-derived district cropland areas explained 84 percent of the variability in data and had a slope of 1.12 .

GCEP30-derived areas provide higher estimates by between 14.4 and 19 percent relative to international and national statistics (table 10; figs. 17 through 20), possibly owing to one or more of the following reasons:

- Objective imagery-based estimates versus subjective national statistics. - National or international statistics are derived using various approaches such as visual estimates collected and collated at various administrative units or a combination of visual estimates, geographic information systems (GIS) data and methods, and (or) satellite imagery. In contrast, GCEP30 primarily used time-series Landsat 30-m-resolution imagery.

- Spatial resolution of imagery.-Differences in spatial resolution of imagery used in different studies have a huge effect on how areas are estimated. Coarser resolution imagery involving 1 to $10 \mathrm{~km}$ ( 1 pixel $=100$ or 10,000 ha, respectively) such as in GIAM and GMRCA require area computation using subpixel fractions (Thenkabail and others, 2007a). In comparison, GCEP30 used high-resolution imagery from Landsat at $30-\mathrm{m}$ resolution $(1$ pixel $=0.09 \mathrm{ha}$ ).

- Methods and approaches used.-GCEP30 used machine learning, a large collection of reference-training and -validation data, and cloud computing, as opposed to the visual estimates, GIS data and methods, and coarser resolution imagery used in other studies. 
Figure 18. Graph comparing netcropland areas, in millions of hectares (Mha), for various countries (dots), showing their areas derived from global cropland-extent product at 30-m resolution (GCEP30) for nominalyear 2015 versus those from Food and Agricultural Organization of the United Nations (FAO) (FA0, 2020). Dashed line shows best-fit equation of GCEP30 versus $F A O$ cropland areas; solid line shows where 1:1 relation of GCEP30 versus $F A O$ cropland areas would plot.

Figure 19. Graph comparing netcropland areas, in millions of hectares (Mha), for various countries (dots), showing their areas derived from global cropland-extent product at 30-m resolution (GCEP30) for nominalyear 2015 versus those from monthly irrigated and rainfed crop areas (MIRCA) database statistics (Portmann and others, 2010). Dashed line shows best-fit equation of GCEP30 versus MIRCA cropland areas; solid line shows where 1:1 relation of GCEP30 versus MIRCA cropland areas would plot.
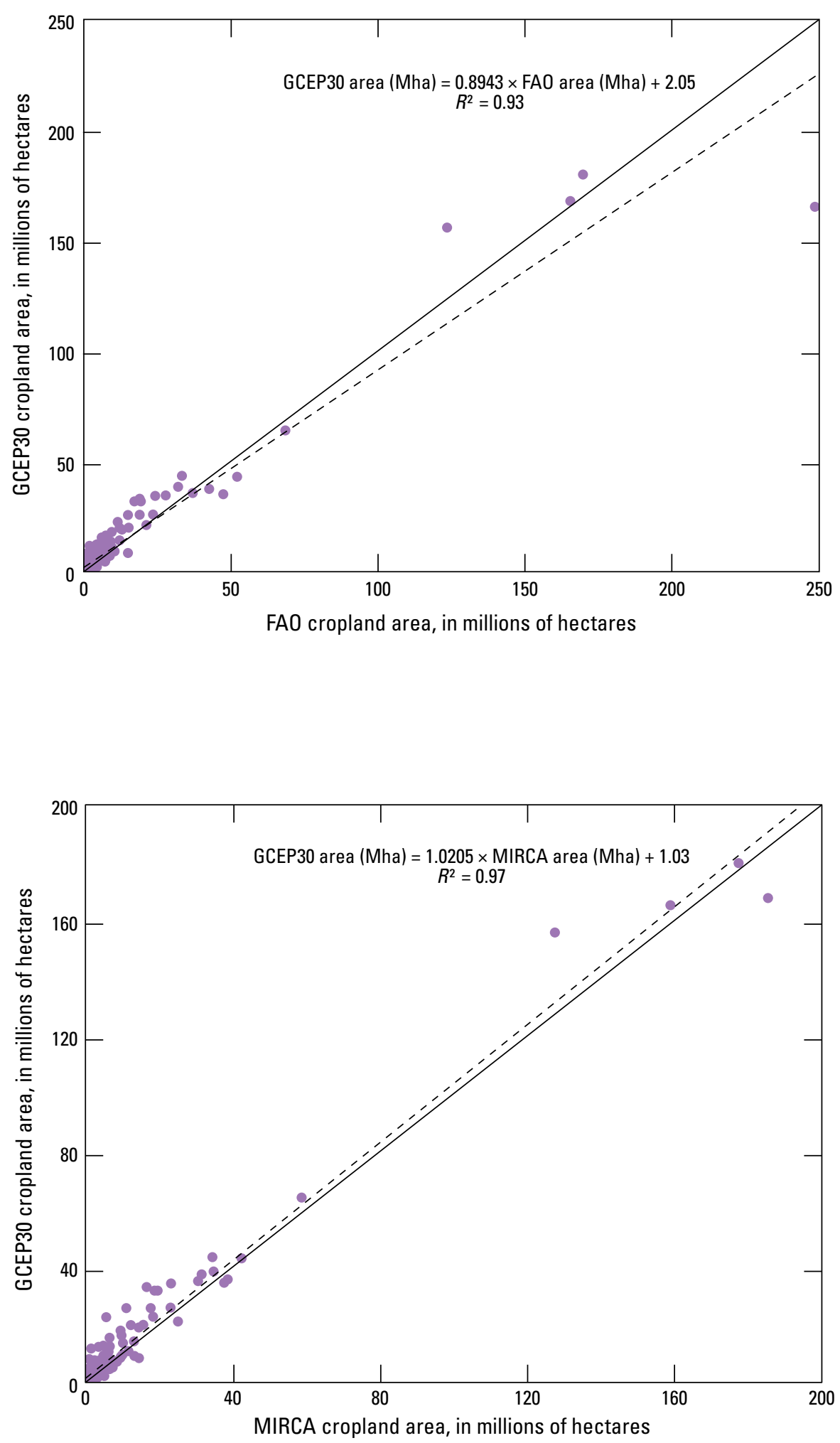

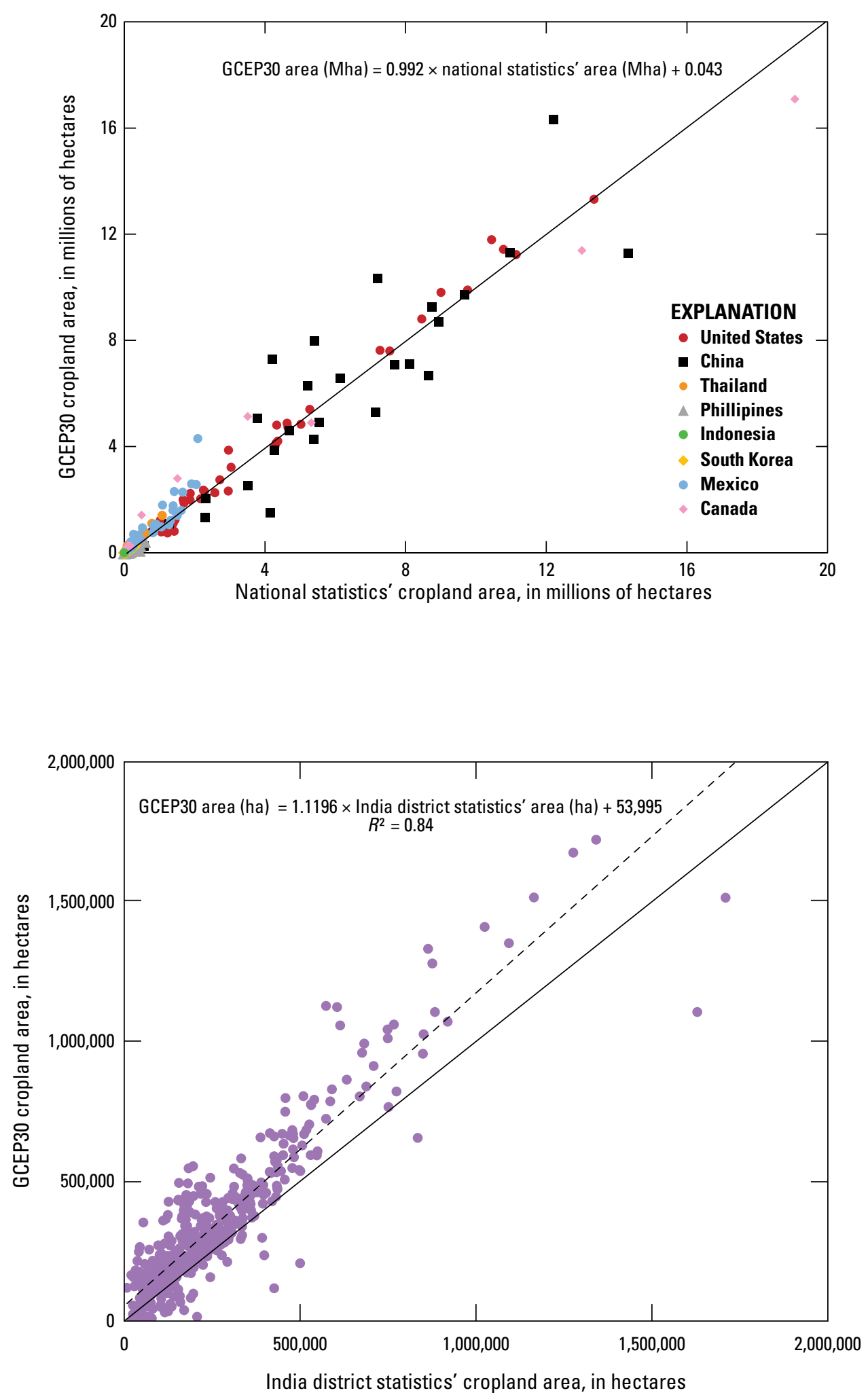

Figure 20. Graph comparing subnational (that is, states, provinces, or regions within nations) net-cropland areas, in millions of hectares (Mha), within various countries, showing areas derived from global cropland-extent product at 30-m resolution (GCEP30) for nominal-year 2015 versus those from national statistics provided by various national agencies. Best-fit equation defines relation of GCEP30 versus national statistics' cropland areas; diagonal line shows where 1:1 relation of GCEP30 versus national statistics' cropland areas would plot.

Figure 21. Graph comparing net-cropland areas, in hectares (ha), for districts in India (dots), showing areas derived from global cropland-extent product at $30-\mathrm{m}$ resolution (GCEP30) for nominal-year 2015 versus those from India districts' statistics. Dashed line shows best-fit equation of GCEP30 versus India district statistics' cropland areas; solid line shows where 1:1 relation of GCEP30 versus India district statistics' cropland areas would plot. 


\section{Significant Findings}

This study produced the world's first 30-m-resolution Landsat-satellite-data-derived global cropland-extent product for the year 2015. This was an extremely complex effort involving many novel data, methods, and approaches, such as petabytescale Landsat time-series big data, analysis ready data (ARD) that were seamlessly stitched for the world on GEE, collection and collation of very large reference-training and -validation data hub, development of MLAs and object-oriented algorithms in the GEE cloud, and cloud computing.

The global cropland-extent product at 30-m resolution (GCEP30) captured 83.4 percent of all cropland, with an overall accuracy of 91.7 percent. In comparison, the overall accuracies of four coarse-resolution global land-cover datasets (Bicheron and others, 2009; Friedl and others, 2010; Yu and others, 2013a, b; Chen and others, 2015) varied between 61.26 percent and 80.63 percent (Chen and others, 2017; Xu and others, 2019; Nabil and others, 2020). Relative to the coarser resolution cropland products, GCEP30 delineated cropland from noncropland with great precision, captured fragmented croplands, established higher accuracies, and provided greater details of each farm.

Thenkabail and others (2009a, 2011) and Biradar and others (2009) reported global agricultural NCAs as 1.529 Bha for the year 2000. In this study, NCAs are reported to be 1.873 Bha for the year 2015, an increase of 22.5 percent (344 Mha). During 2015, the world population increased by about 20 percent, from 6.122 billion in 2000 to 7.358 billion in 2015 (UN, 2018, 2019). Therefore, the global population increase of 20 percent is compensated by the global cropland-area increase of 22.5 percent. Notably, this increase is also tied to the data, methods, and approaches used. This study used 30-m-resolution Landsat time-series data, as opposed to that of Thenkabail and others (2009a, 2011) and Biradar and others (2009), who used 1- to 10-km-resolution data. GCEP30 captures fragmented croplands and, thus, has greater precision and accuracies in capturing cropland; its ability to capture real areas—as opposed to the subpixel areas (Thenkabail and others, 2007a) of GIAM and GMRCA — also is a significant factor.

GCEP30-derived cropland areas of the year 2015 (fig. 7; table 10; see also, www.croplands.org) were compared with cropland areas of the year 2000 that were derived by taking the average of three studies (FAOSTAT, MIRCA2000, and GIAM and GMRCA) for 10 leading agricultural countries (table 17). These 10 countries (table 17) occupy about 50 percent of the world's cropland areas and 52 percent of its population (table 17). Cropland areas in these countries only increased by 1.8 percent (from 913 Mha in 2000 to 930 Mha in 2015), whereas the population grew by 15.5 percent (from 3.3 to 3.8 billion, an increase of 517 million people) (table 17). From 2000 to 2015, cropland areas of United States and Canada decreased about 2 percent, despite the population of United States increasing by about 14 percent (from 282 to 321 million) and Canada’s population increasing by about 13 percent (from 31 to 35 million). However, United States exported about $\$ 135$ billion (U.S. dollars) worth of agricultural products in 2015 that included grains, feeds, and soybeans (Jiang and others, 2015). In both countries, food production per unit area increased, as did virtual food (that is, food imported from other countries), thus maintaining food security, despite a population increase and only a minor increase in cropland. Furthermore, for food and nutritional variety, these countries ensure food security and nutrition diversity by virtual food trade (Tramberend and others, 2019).

Notable changes have occurred in croplands in many countries. For example, China and India have the highest areas of agricultural cropland in the world, and together they have 35 percent of the world's population. China's population increased by 10 percent between 2000 and 2015 (1.24 to 1.37 billion; UN, 2019); however, China's cropland areas decreased by 18.9 percent (38.4 Mha, from 203.6 to 165.2 Mha) (table 17). This decrease was validated by Shi and others (2016), who reported a decrease of 33 Mha during about the same time period. Most studies (see, for example, Huang and others, 2017) anticipated that China will increase its food and feed imports in the coming decade because its overall food self-sufficiency is likely to decrease from 94.5 percent in 2015 to about 91 percent by 2025 . China became the country that has the highest amount of food imports in 2011, and, in the year 2017, it imported 53.48 million tons of food and beverage, which had a value of $\$ 58.28$ billion (U.S. dollars) (Trade Commissioner Service, 2019).

Cropland-area decreases are the main cause of China's decrease in food self-sufficiency. The reasons for China's decrease in cropland area are urban expansion in cropland areas and the abandonment of cropland owing to demographic changes, with rural populations moving into urban areas (Shi and others, 2016; see also, fig. 22, this report).

In contrast, India's cropland areas increased by 8.5 percent (14 Mha, from 165.7 Mha in 2000 to 179.8 Mha in 2015) (table 17). During the same time period, India's population increased by about 20 percent, from 1.04 billion in 2000 to 1.25 billion in 2015 (UN, 2019). The causes of this increase (fig. 23) can be attributed to the expansion of cropland to hitherto noncropland areas and the ability of the GCEP30 product to capture fragmented cropland areas.

India had a population increase of about 20 percent and an 8.5 percent (14 Mha) increase in cropland areas from 2000 to 2015 (table 17), whereas China had a population increase of 10 percent and an 18.9 percent (38.4 Mha) decrease in cropland areas from 2000 to 2015. Zhou and others (2016) and Zhang and others (2017) validated this trend by showing that China's rice areas decreased by 18 percent between 2000 and 2015, whereas India's rice areas increased by 19 percent between 2000 and 2015. It is worth noting that India has achieved exportable levels of surplus wheat and rice (Shikha and Srinivasan, 1999). However, about 20 percent of India's population lives on less than $\$ 1.90$ (U.S. dollars) a day. In addition, the country houses one quarter of all undernourished people in the world (World Food Program USA, 2020); India has 190.7 million undernourished people, which was 14.5 percent of the population in 2015 (FAO and others, 2017).

Of the 10 largest cropland-area countries, four countries (Ukraine, Nigeria, Russia, and Indonesia) showed an 18 to 


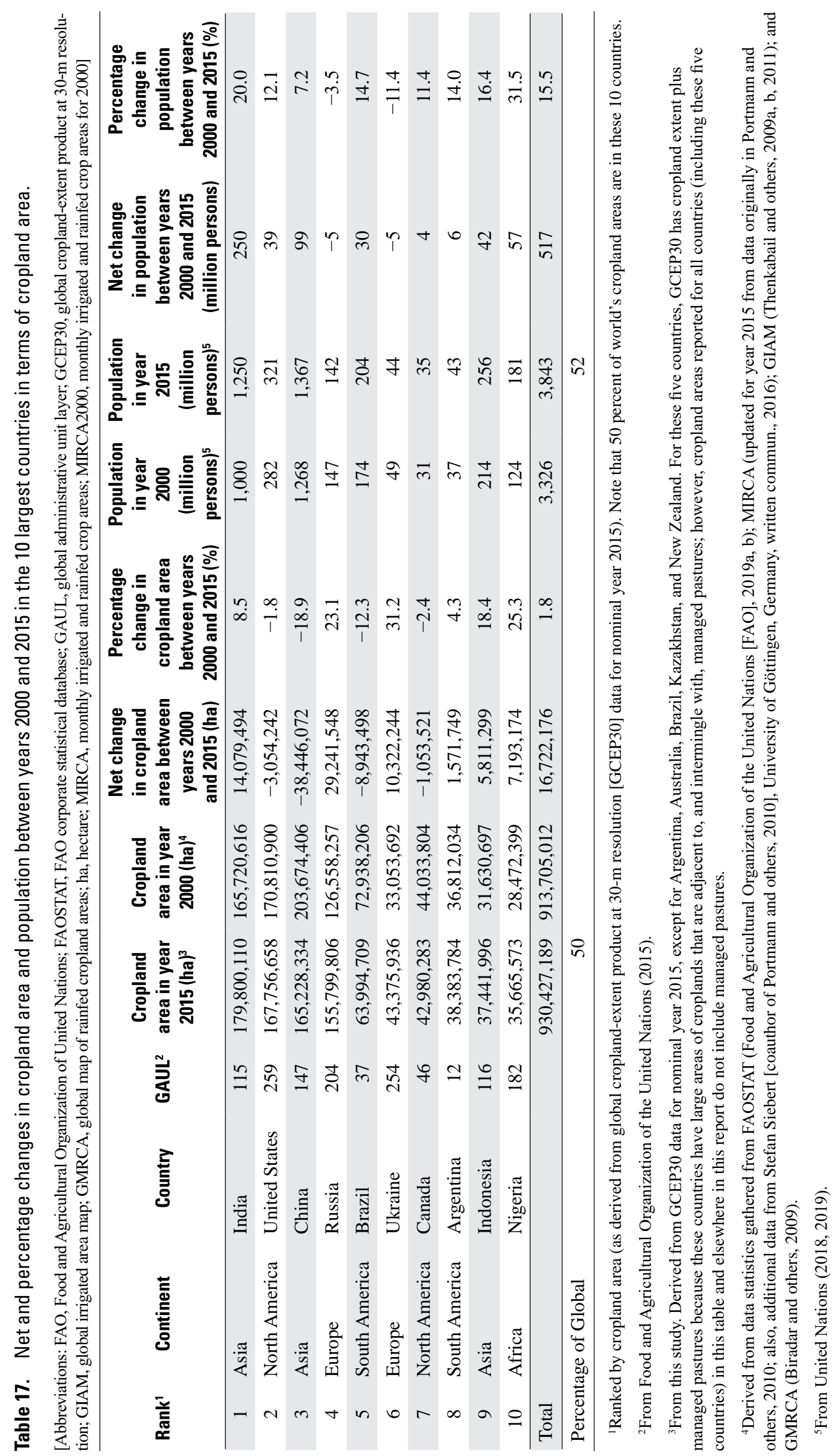



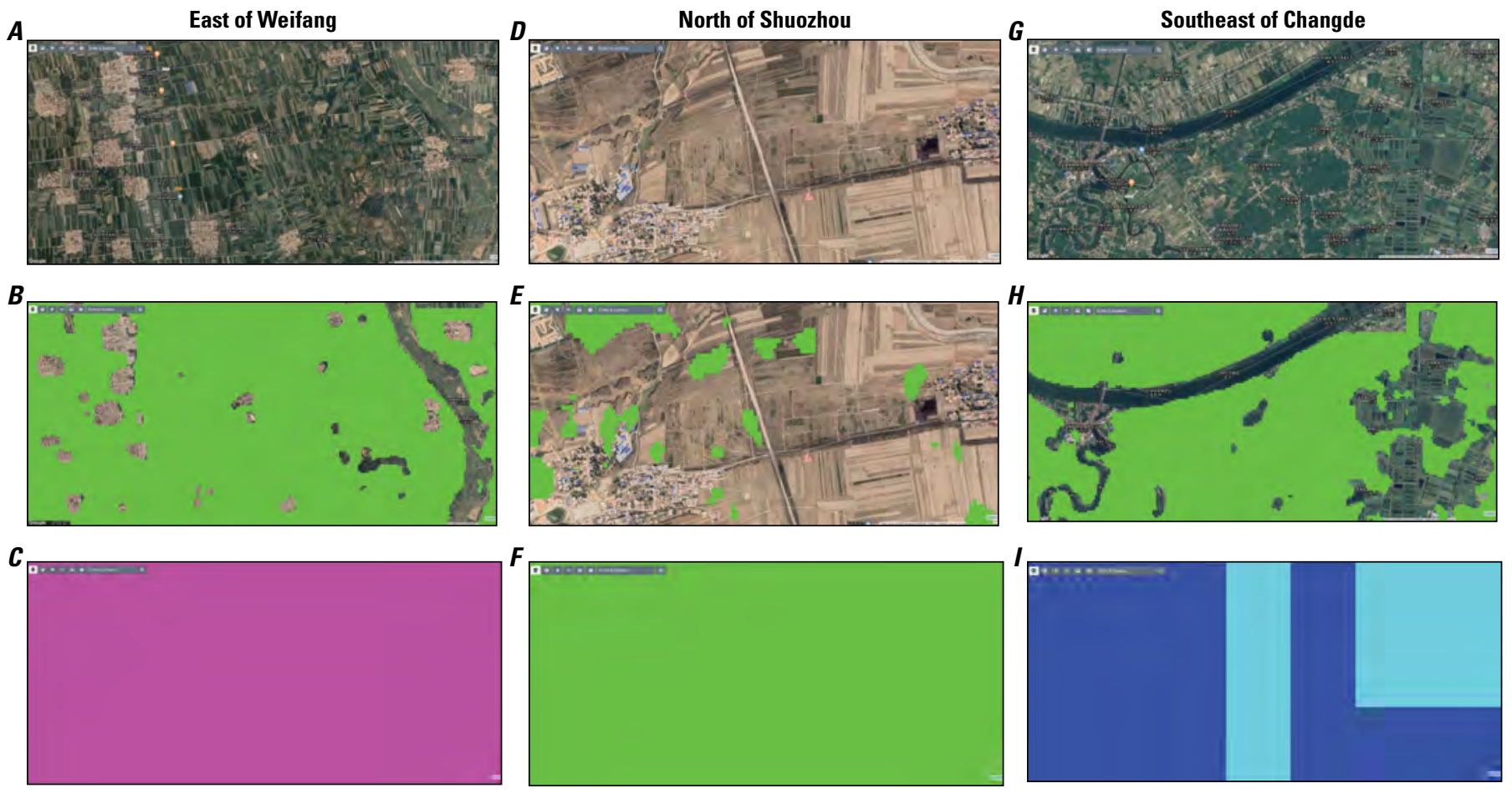

Figure 22. Screen captures of close-up views of cropland areas mapped in China $(A, B, C$, east of Weifang; $D, E$, $F$, north of Shuozhou; and $G$, $H$, I, southeast of Changde), illustrating some causes of cropland decreases in China. $A, D, G$, Unmapped Landsat submeter- to 5-m-resolution images for reference. $B, E, H$, Same areas as $A, D$, and $G$, showing cropland (green shading) mapped from global cropland-extent product at 30-m resolution (GCEP30; see fig. 7) for nominal-year 2015. C, F, I, Same areas as $A, D$, and $G$, showing cropland (green, blue, and magenta pixels) mapped from coarser resolution (1 km) GIAM/GMRCA product for nominal-year 2000. Top images $(A, B, C)$ show urban expansion captured by GCEP30 $(B)$ but missing in GIAM/GMRCA $(C)$ : in $B$, significant cropland areas have been urbanized; in $C$, entire area was mapped as cropland. Center images $(D, E, F)$ show abandoned cropland captured by GCEP30 ( $E$ ) but missing in GIAM/GMRCA (F): in $E$, some cropland areas have been urbanized or abandoned; in $F$, entire area was mapped as cropland. Bottom images $(G, H$, $\Lambda$ ) show cropland separated from aquaculture captured by GCEP30 $(H)$ but missing in GIAM/GMRCA (I): in $H$, some cropland areas are now aquaculture; in $I$, entire area was mapped as cropland. Base map images from Google Earth (used with permission).

31 percent increase in cropland areas by the year 2015 when compared to 2000. Cropland areas in Ukraine and Russia increased by 31 and 23 percent, respectively, between 2000 and 2015 (table 17). In Ukraine, cropland increased by 10.3 Mha between 2000 and 2015, from 33 to 43.3 Mha (table 17). However, the dissolution of the Union of Soviet Socialist Republics (USSR) in 1991 resulted in large-scale abandonment of croplands: by the year 2005, 4 to 9.2 Mha had been abandoned (Alcantara and others, 2012, 2013; State Statistics Service of Ukraine, 2013). Following the dissolution of the USSR, Russia had the largest area (32.2 Mha) of abandoned farmland, followed by Ukraine (9.2 Mha), Belarus (3.4 Mha), Poland (1.5 Mha), Romania (1.0 Mha), Lithuania (0.9 Mha), and Latvia (0.6 Mha) (Alcantara and others, 2013). Belarus had the highest abandonment rate (34 percent), followed by Latvia (27.6 percent), Lithuania (23.7 percent), and Russia (22.5 percent) (table 1). Ukraine, Republic of Moldova, and Estonia also had high abandonment rates (20.5 percent, 18.9 percent, and 16.8 percent, respectively) (Alcantara and others, 2013). Starting in 2005, significant portions of these croplands in Russia and Ukraine apparently were recultivated; however, in this study we map cropland fallows (which includes abandoned croplands) as cropland. Therefore, it is not known exactly how much of the croplands mapped by GCEP30 in Ukraine were actually cultivated with annual crops or plantations or left fallow. Russia's population decreased by 3.5 percent and that of Ukraine decreased by 11.4 percent during the same time period (2000-2015).

In Nigeria, NCAs increased by 25 percent (7.2 Mha) (table 17). In Africa, an increase in cropland of 11 Mha occurred between 2000 and 2013 (Cotillon and Tappan, 2016), and in Nigeria, the population increased by 31 percent during the same period. Indonesia had an increase in NCAs of 18 percent (5.8 Mha) between 2000 and 2015 (table 17), and in the same period, its population grew by 16 percent. Thus, these increases in cropland areas were crucial to maintaining food security.

Trends in two South American countries are noteworthy: in Argentina, both population and cropland areas increased by about 4 percent (1.5 Mha), and in Brazil, the population increased by 14.7 percent while cropland decreased by 12.3 percent (8.9 Mha) (table 17). The decrease in cropland in Brazil probably is due to the abandonment of croplands from earlier forest clearings or pastureland conversions. 



Figure 23. Screen captures of close-up views of cropland areas mapped in India $(A, B, C$, Rajasthan; $D, E, F$, Chhattisgarh; and $G, H, I$, Kerala), illustrating some causes of cropland increases in India. $A, D, G$, Unmapped Landsat submeter- to 5-m-resolution images for reference. $B, E, H$, Same areas as $A, D$, and $G$, showing cropland (green shading) mapped from global cropland-extent product at 30-m resolution (GCEP30; see fig. 7) for nominal-year 2015 in which cropland fractions are clearly distinguished from noncropland fractions. $C, F, I$, Same areas as $A, D$, and $G$, showing noncropland (brown pixels) mapped from coarser resolution (1 km) GIAM/GMRCA product for nominal-year 2000. In $B$, most of area was mapped as cropland; in $C$, entire area was mapped as noncropland. In $E$, significant areas were mapped as cropland; in $F$, entire area was mapped as noncropland. In $H$, cropland areas are fragmented; in $I$, entire area was mapped as noncropland. Base map images from Google Earth (used with permission).

In figure 23, noncropland areas are clearly separated from cropland areas in three distinct instances in GCEP30, compared to the reference images, whereas, in the global irrigated area map (GIAM) and global map of rainfed cropland areas (GMRCA) products, the entire area (cropland and noncropland) is mapped as a single class (that is, a minor cropland fraction). The ability of GCEP30 to better (that is, more precisely than from coarser resolution images) delineate croplands from noncroplands leads to more reliable and accurate estimates of cropland areas.

However, it must be noted that not all perceived changes are actual changes. The GCEP30 used the highest known spatial resolution ( 1 pixel $=0.09$ ha) to map cropland areas, which resulted in the ability to capture cropland fractions and small farms. Consistent application of methods and approaches using a large high-quality reference training and validation data of the world helps in establishing a uniform accuracy assessment. In comparison, a number of differences were evident in previous studies relative to GCEP30, including the type of data used (remote sensing versus non-remote sensing), the spatial resolution (30 m [1 pixel = 0.09 ha] versus, for example, $250 \mathrm{~m}$ [ 1 pixel $=6.25$ ha]), the methods and approaches used, the uncertainties and the definitions of the products produced, and the misreporting of statistics by some countries.

\section{Conclusions}

There were five significant or novel achievements of this study. First, this study created a Landsat-satellite-derived global cropland-extent product at 30-meter (m) resolution (GCEP30), which has the highest spatial resolution (1 pixel = 0.09 hectares [ha]) of any other global cropland product to date (2021). Second, the product was the result of a paradigm shift in producing cropland-extent maps that included petabyte-scale computing, the development of large reference-training and validation data hub for machine learning, the use of pixel-based supervised machine-learning algorithms in conjunction with the object-based recursive hierarchical segmentation, and the use of software and computing on the Google Earth Engine (GEE) cloud-computing platform.

Third, the study derived cropland areas for every country in the world for the year 2015 using the highest known resolution 
product (GCEP30). Fourth, very comprehensive accuracy assessments were performed that were based on rich global-validation datasets for the 74 agroecological zones (AEZs) of the world.

Fifth, the study provided several comparative statistics such as cropland area per person per country, cropland area per country, cropland areas as percentage of the geographic area of the country, and spatial and temporal changes in cropland area, all of which would benefit global food and water security assessments and analysis.

The GCEP30 products, which can be viewed at full resolution at www.croplands.org, can be downloaded from the Land Processes Distributed Active Archive Center (U.S. Geological Survey and National Aeronautics and Space Administration, 2017; https://lpdaac.usgs.gov/news/release-of-gfsad-30-meter-croplandextent-products/). The GCEP30 data have been used by over 100 countries and have been downloaded, on average, by about 20 countries per month since their release four years ago.

\section{References Cited}

Alcantara, C., Kuemmerle, T., Baumann, M., Bragina, E.V., Griffiths, P., Hostert, P., Knorn, J., Müller, D., Prishchepov, A.V., Schierhorn, F., Sieber, A., and Radeloff, V.C., 2013, Mapping the extent of abandoned farmland in Central and Eastern Europe using MODIS time series satellite data: Environmental Research Letters, v. 8, no. 3, 9 p., https://doi. org/10.1088/1748-9326/8/3/035035.

Alcantara, C., Kuemmerle, T., Prishchepov, A.V., and Radeloff, V.C., 2012, Mapping abandoned agriculture with multi-temporal MODIS satellite data: Remote Sensing of Environment, v. 124, p. 334-347.

Badami, M.G., and Ramankutty, N., 2015, Urban agriculture and food security-A critique based on an assessment of urban land constraints: Global Food Security, v. 4, p. 8-15.

Banfield, R.E., Hall, L.O., Bowyer, K.W., and Kegelmeyer, W.P., 2007, A comparison of decision tree ensemble creation techniques: IEEE Transactions on Pattern Analysis and Machine Intelligence, v. 29, no. 1, p. 173-180.

Bartholomé, E., and Belward, A.S., 2005, GLC2000—A new approach to global land cover mapping from Earth observation data: International Journal of Remote Sensing, v. 26, no. 9, p. 1959-1977, https://doi.org/10.1080/0143116 0412331291297.

Becker-Reshef, I., Justice, C., Sullivan, M., Vermote, E., Tucker, C., Anyamba, A., Small, J., Pak, E., Masuoka, E., Schmaltz, J., Hansen, M., Pittman, K., Birkett, C., Williams, D., Reynolds, C., and Doorn, B., 2010, Monitoring global croplands with coarse resolution earth observations-The global agriculture monitoring (GLAM) project: Remote Sensing, v. 2, no. 6, p. 1589-1609.
Bicheron, P., Defourny, P., Brockmann, C., Schouten, L., Vancutsem, C., Huc, M., Bontemps, S., Leroy, M., Achard, F., Herold, M., Ranera, F., and Arino, O., 2009, GLOBCOVER products description and validation report: Medias France/ Postel, 47 p., accessed June 2017 at http://due.esrin.esa.int/files/ GLOBCOVER_Products_Description_Validation_Report I2.1.pdf.

Biradar, C.M., Thenkabail, P.S., Noojipady, P., Li, Y., Dheeravath, V., Turral, H., Velpuri, M., Gumma, M.K., Gangalakunta, O.R.P., Cai, X.L., Xiao, X., Schull, M.A., Alankara, R.D., Gunasinghe, S., and Mohideen, S., 2009, A global map of rainfed cropland areas (GMRCA) at the end of last millennium using remote sensing: International Journal of Applied Earth Observation and Geoinformation, v. 11, no. 2, p. 114-129, https://doi.org/10.1016/j.jag.2008.11.002.

Bodirsky, B.L., Rolinski, S., Biewald, A., Weindl, I., Popp, A., and Lotze-Campen, H., 2015, Global food demand scenarios for the 21st century: PloS ONE, v. 10, no. 11, e0139201, 27 p.

Brown, J.C., Kastens, J.H., Coutinho, A.C., de Castro Victoria, D., and Bishop, C.R., 2013, Classifying multiyear agricultural land use data from Mato Grosso using time-series MODIS vegetation index data: Remote Sensing of Environment, v. 130, p. 39-50.

Campbell, B.M., Thornton, P., Zougmoré, R., van Asten, P., and Lipper, L., 2014, Sustainable intensification-What is its role in climate smart agriculture?: Current Opinion in Environmental Sustainability, v. 8, p. 39-43.

Chen, J., Chen, J., Liao, A., Cao, X., Chen, L., Chen, X., He, C., Han, G., Peng, S., Lu, M., Zhang, W., Tong, X., and Mills, J., 2015, Global land cover mapping at $30 \mathrm{~m}$ resolution-A POK-based operational approach: ISPRS Journal of Photogrammetry and Remote Sensing, v. 103, p. 7-27.

Chen, X.-Y., Lin, Y., Zhang, M., Yu, L., Li, H.-C., and Bai, Y.-Q., 2017, Assessment of the cropland classifications in four global land cover datasets - A case study of Shaanxi Province, China: Journal of Integrative Agriculture, v. 16, no. 2, p. 298-311, https://doi.org/10.1016/S2095-3119(16)61442-9.

Congalton, R., Yadav, K., McDonnell, K., Poehnelt, J., Stevens, B., Gumma, M., Teluguntla, P., and Thenkabail, P., 2017, GFSAD30VAL v001 - Global food security-support analysis data (GFSAD) cropland extent 2015 validation $30 \mathrm{~m}$ : U.S. Geological Survey-National Aeronautics and Space Administration Land Processes Distributed Active Archive Center website, https://doi.org/10.5067/MEaSUREs/GFSAD/ GFSAD30VAL.001.

Congalton, R.G., 2015, Assessing positional and thematic accuracies of maps generated from remotely sensed data, chap. 29 in Thenkabail, P.S., ed., Remotely sensed data characterization, classification, and accuracies, vol. I of Remote sensing handbook-Three volume set: Boca Raton, Fla., London, United Kingdom, and New York, N.Y., CRC Press/Taylor \& Francis Group, p. 583-602. 
Congalton, R.G., and Green, K., 2009, Assessing the accuracy of remotely sensed data-Principles and practices (2d ed.): Boca Raton, Fla., CRC Press, 200 p., https://doi. org/10.1201/9781420055139.

Congalton, R.G., Gu, J., Yadav, K., Thenkabail, P., and Ozdogan, M., 2014, Global land cover mapping-A review and uncertainty analysis: Remote Sensing, v. 6, no. 12, p. 12,070-12,093.

Conrad, C., Lamers, J.P.A., Ibragimov, N., Löw, F., and Martius, C., 2016, Analysing irrigated crop rotation patterns in arid Uzbekistan by the means of remote sensing-A case study on post-Soviet agricultural land use: Journal of Arid Environments, v. 124, p. $150-159$.

Corrado, S., and Sala, S., 2018, Food waste accounting along global and European food supply chains - State of the art and outlook: Waste Management, v. 79, p. 120-131, https://doi. org/10.1016/j.wasman.2018.07.032.

Cotillon, S.E., and Tappan, G.G., 2016, Landscapes of West Africa-A window on a changing world: Garretson, S.D., U.S. Geological Survey, Earth Resources Observation and Science (EROS) Center, Monograph, 219 p., https://pubs.er.usgs.gov/ publication/70176549.

Dalin, C., and Konar, M., 2019, Virtual water trade among world countries associated with food trade, in Ferranti, P., Berry, E.M., and Anderson, J.R., eds., Encyclopedia of Food Security and Sustainability: Amsterdam, Netherlands, Elsevier, p. 74-81, https://doi.org/10.1016/B978-0-08-100596-5.22500-6.

Dalin, C., Konar, M., Hanasaki, N., Rinaldo, A., and RodriguezIturbe, I., 2012, Evolution of the global virtual water trade network: Proceedings of the National Academy of Sciences, v. 109, no. 16, p. 5989-5994, https://doi.org/10.1073/ pnas.1203176109.

Defourny, P., Schouten, L., Bartalev, S., Bontemps, S., Cacetta, P., de Wit, A.J.W., Di Bella, C., Gérard, B., Giri, C., Gond, V., Hazeu, G.W., Heinimann, A., Herold, M., Jaffrain, G., Latifovic, R., Lin, H., Mayaux, P., Mücher, C.A., Nonguierma, A., Stibig, H.-J., Van Bogaert , E., Vancutsem, C., Bicheron, P., Leroy, M., and Arino, O., 2009, Accuracy assessment of a $300 \mathrm{~m}$ global land cover map - The GlobCover experience: Stresa, Italy, 33rd International Symposium on Remote Sensing of Environment, 5 p., https://edepot.wur.nl/14725.

Defourny, P., Bontemps, S., Lamarche, C., Brockmann, C., Boettcher, M., Wevers, J., and Kirches, G., 2017, Land cover CCI-Product user guide, version 2.5: UCL-Geomatics, 91 p., accessed June 2017 at http://maps.elie.ucl.ac.be/CCI/ viewer/download/ESACCI-LC-PUG-v2.5.pdf.

DeFries, R.S., and Chan, J.C.-W., 2000, Multiple criteria for evaluating machine learning algorithms for land cover classification from satellite data: Remote Sensing of Environment, v. 74, no. 3, p. 503-515.
Delzeit, R., Zabel, F., Meyer, C., and Václavík, T., 2017, Addressing future trade-offs between biodiversity and cropland expansion to improve food security: Regional Environmental Change, v. 17, no. 5, p. 1429-1441, https:// doi.org/10.1007/s10113-016-0927-1.

Deng, C., and Wu, C., 2013, The use of single-date MODIS imagery for estimating large-scale urban impervious surface fraction with spectral mixture analysis and machine learning techniques: ISPRS Journal of Photogrammetry and Remote Sensing, v. 86, p. 100-110.

Depenbusch, L., and Klasen, S., 2019, The effect of bigger human bodies on the future global calorie requirements: PLoS One, v. 14, no. 12, 15 p., https://doi.org/10.1371/ journal.pone.0223188.

Dheeravath, V., Thenkabail, P.S., Chandrakantha, G., Noojipady, P., Reddy, G.P.O., Biradar, C.M., Gumma, M.K., and Velpuri, M., 2010, Irrigated areas of India derived using MODIS 500 $\mathrm{m}$ time series for the years 2001-2003: ISPRS Journal of Photogrammetry and Remote Sensing, v. 65, no. 1, p. 42-59, https://doi.org/10.1016/j.isprsjprs.2009.08.004.

Dong, J., Xiao, X., Kou, W., Qin, Y., Zhang, G., Li, L., Jin, C., Zhou, Y., Wang, J., Biradar, C., Lui, J., and Moore, B., III, 2015, Tracking the dynamics of paddy rice planting area in 1986-2010 through time series Landsat images and phenology-based algorithms: Remote Sensing of Environment, v. 160, p. 99-113.

Duarte, R., Pinilla, V., and Serrano., A., 2019, Long term drivers of global virtual water trade - A trade gravity approach for 1965-2010: Ecological Economics, v. 156, p. 318-326, https:// doi.org/10.1016/j.ecolecon.2018.10.012.

Duveiller, G., Lopez-Lozano, R., and Cescatti, A., 2015, Exploiting the multi-angularity of the MODIS temporal signal to identify spatially homogeneous vegetation coverA demonstration for agricultural monitoring applications: Remote Sensing of Environment, v. 166, p. 61-77.

Egorov, A.V., Hansen, M.C., Roy, D.P., Kommareddy, A., and Potapov, P.V., 2015, Image interpretation-guided supervised classification using nested segmentation: Remote Sensing of Environment, v. 165, p. 135-147.

Egorov, A.V., Roy, D.P., Zhang, H.K., Li, Z., Yan, L., and Huang, H., 2019, Landsat 4, 5 and 7 (1982 to 2017) analysis ready data (ARD) observation coverage over the conterminous United States and implications for terrestrial monitoring: Remote Sensing, v. 11, no. 447, 19 p.

Estel, S., Kuemmerle, T., Alcántara, C., Levers, C., Prishchepov, A., and Hostert, P., 2015, Mapping farmland abandonment and recultivation across Europe using MODIS NDVI time series: Remote Sensing of Environment, v. 163, p. 312-325. 
Feng, D., Zhao, Y., Yu, L., Li, C., Wang, J., Clinton, N., Bai, Y., Belward, A., Zhu, Z., and Gong, P., 2014, Circa 2014 African land-cover maps compatible with FROM-GLC and GLC2000 classification schemes based on multi-seasonal Landsat data: International Journal of Remote Sensing, v. 37, no. 19, p. 4648-4664.

Fischer, G., van Velthuizen, H., and Nachtergaele, F.O., 2000, Global agroecological zones assessment-Methodology and results: International Institute for Applied Systems Analysis, Interim Report IR-00-064, 314 p.

Foley, J.A., Ramankutty, N., Brauman, K.A., Cassidy, E.S., Gerber, J.S., Johnston, M., Mueller, N.D., O'Connell, C., Ray, D.K., West, P.C., Balzer, C., Bennett, E.M., Carpenter, S.R., Hill, J., Monfreda, C., Polasky, S., Rockström, J., Sheehan, J., Siebert, S., Tilman., D., and Zaks, D.P.M., 2011, Solutions for a cultivated planet: Nature, v. 478, p. 337-342, https://doi. org/10.1038/nature10452.

Food and Agricultural Organization of the United Nations [FAO], 2015, Global administrative unit layers (GAUL): Food and Agricultural Organization of the United Nations, FAO Map Catalog, available at https://data.apps.fao.org/map/catalog/ srv/eng/catalog.search\#/metadata/9c35ba10-5649-41c8-bdfceb78e9e65654.

Food and Agricultural Organization of the United Nations [FAO], 2017, The future of food and agriculture-Trends and challenges: Rome, Italy, Food and Agricultural Organization of the United Nations, 163 p., accessed March 2020 at http://www. fao.org/3/a-i6583e.pdf.

Food and Agricultural Organization of the United Nations [FAO], 2019a, Climate-smart agriculture and the Sustainable Development Goals-Mapping interlinkages, synergies and trade-offs and guidelines for integrated implementation: Rome, Italy, Food and Agricultural Organization of the United Nations, 144 p. [Also available at http://www.fao.org/publications/card/ en/c/CA6043EN/.]

Food and Agricultural Organization of the United Nations [FAO], 2019b, Main results and metadata by country (2006-2015) World programme for the Census of Agriculture 2010: Rome, Italy, Food and Agricultural Organization of the United Nations, FAO Statistical Development Series No. 17, 381 p.

Food and Agricultural Organization of the United Nations [FAO], 2020, FAOSTAT - Land Use: Rome, Italy, Food and Agricultural Organization of the United Nations website, http://www.fao.org/faostat/en/\#data/RL/visualize.

Food and Agricultural Organization of the United Nations, International Fund for Agricultural Development, United Nations Children's Emergency Fund, World Food Program, and World Health Organization [FAO and others], 2017, The state of food security and nutrition in the world 2017-Building resilience for peace and food security: Rome, Italy, Food and Agricultural Organization of the United Nations, $119 \mathrm{p}$.
Food and Agricultural Organization of the United Nations and International Institute of Applied System Analysis, 2012, Global agro-ecological zones (GAEZ ver. 3.0)-Model documentation: Laxenburg, Austria, and Rome, Italy, International Institute of Applied System Analysis (IIASA) and Food and Agricultural Organization of the United Nations (FAO), 179 p., accessed April 2020 at http://www.fao.org/nr/gaez/en/.

Forster, J., and Radulovich, R., 2015, Seaweed and food security, chap. 11 in Tiwari, B.K., and Troy, D.J., Seaweed sustainability: Amsterdam, Netherlands, Elsevier, p. 289-313, https://doi. org/10.1016/B978-0-12-418697-2.00011-8.

Friedl, M.A., and Brodley, C.E., 1997, Decision tree classification of land cover from remotely sensed data: Remote Sensing of Environment, v. 61, no. 3, p. 399-409.

Friedl, M.A., Sulla-Menashe, D., Tan, B., Schneider, A., Ramankutty, N., Sibley, A., and Huang, X., 2010, MODIS Collection 5 global land cover-Algorithm refinements and characterization of new datasets: Remote Sensing of Environment, v. 114, no. 1, p. 168-182, https://doi.org/10.1016/j.rse.2009.08.016.

Fritz, S., 2017, Book review, European landscape dynamicsCORINE land cover data: International Journal of Applied Earth Observation and Geoinformation, v. 59, p. 63-64, https:// doi.org/10.1016/j.jag.2017.02.020.

Fritz, S., See, L., McCallum, I., You, L., Bun, A., Moltchanova, E., Duerauer, M., Albrecht, F., Schill, C., Perger, C., Havlik, P., Mosnier, A., Thornton, P., Wood-Sichra, U., Herrero, M., Becker-Reshef, I., Justice, C., Hansen, M., Gong, P., Abdel Aziz, S., Cipriani, A., Cumani, R., Cecchi, G., Conchedda, G., Ferreira, S., Gomez, A., Haffani, M., Kayitakire, F., Malanding, J., Mueller, R., Newby, T., Nonguierma, A., Olusegun, A., Ortner, S., Rajak, D.R., Rocha, J., Schepaschenko, D., Schepaschenko, M., Terekhov, A., Tiangwa, A., Vancutsem, C., Vintrou, E., Wenbin, W., van der Velde, M., Dunwoody, A., Kraxner, F., and Obersteiner, M., 2015, Mapping global cropland and field size: Global Change Biology, v. 21, no. 5, p. 1980-1992.

Fritz, S., See, L., You, L., Justice, C., Becker-Reshef, I., Bydekerke, L., Cumani, R., Defourny, P., Erb, K., Foley, J., Gilliams, S., Gong, P., Hansen, M., Hertel, T., Herold, M., Herrero, M., Kayitakire, F., Latham, J., Leo, O., McCallum, I., Obersteiner, M., Ramankutty, N., Rocha, J., Tang, H., Thornton, P., Vancutsem, C., Van Der Velde, M., Wood, S., and Woodcock, C., 2013, The need for improved maps of global cropland: Eos, Transactions, American Geophysical Union, v. 94, no. 3, p. 31-32.

Fritz, S., See, L.M., and Rembold, F., 2010, Comparison of global and regional land cover maps with statistical information for the agricultural domain in Africa: International Journal of Remote Sensing, v. 31, no. 9, p. 2237-2256, https://doi. org/10.1080/01431160902946598.

Gbegbelegbe, S., Chung, U., Shiferaw, B., Msangi, S., and Tesfaye, K., 2014, Quantifying the impact of weather extremes on global food security - A spatial bio-economic approach: Weather and Climate Extremes, v. 4, p. 96-108. 
Geerken, R., Zaitchik, B., and Evans, J.P., 2005, Classifying rangeland vegetation type and coverage from NDVI time series using Fourier Filtered Cycle Similarity: International Journal of Remote Sensing, v. 26, no. 24, p. 5535-5554.

Gerland, P., Raftery, A.E., Ševčíková, H., Li, N., Gu, D., Spoorenberg, T., Alkema, L., Fosdick, B.K., Chunn, J., Lalic, N., Bay, G., Buettner, T., Heilig, G.K., and Wilmoth, J., 2014, World population stabilization unlikely this century: Science, v. 346, no. 6206, p. 234-237, https://doi. org/10.1126/science. 1257469 .

Giri, C., Zhu, Z., and Reed, B., 2005, A comparative analysis of the Global Land Cover 2000 and MODIS land cover data sets: Remote Sensing of Environment, v. 94, no. 1, p. 123-132.

Gislason, P.O., Benediktsson, J.A., and Sveinsson, J.R., 2006, Random Forests for land cover classification: Pattern Recognition Letters, v. 27, no. 4, p. 294-300.

Gong, P., Liu, H., Zhang, M., Li, C., Wang, J., Huang, H., Clinton, N., Ji, L., Li, W., Bai, Y., Chen, B., Xu, B., Zhu, Z., Yuan, C., Suen, H.P., Guo, J., Xu, N., Li, W., Zhao, Y., Yang, J., Yu, C., Wang, X., Fu, H., Yu, L., Dronova, I., Hui, F., Cheng, X., Shi, X., Xiao, F., Liu, Q., and Song, L., 2019, Stable classification with limited sample-Transferring a 30-m resolution sample set collected in 2015 to mapping 10-m resolution global land cover in 2017: Science Bulletin, v. 64, no. 6, p. 370-373, https://doi. org/10.1016/j.scib.2019.03.002.

Gong, P., Wang, J., Yu, L., Zhao, Y., Zhao, Y., Liang, L., Niu, Z., Huang, X., Fu, H., Liu, S., Li, C., Li, X., Fu, W., Liu, C., Xu, Y., Wang, X., Cheng, Q., Hu, L., Yao, W., Zhang, H., Zhu, P., Zhao, Z., Zhang, H., Zheng, Y., Ji, L., Zhang, Y., Chen, H., Yan, A., Guo, J., Yu, L., Wang, L., Liu, X., Shi, T., Zhu, M., Chen, Y., Yang, G., Tang, P., Xu, B., Giri, C., Clinton, N., Zhu, Z., Chen, J., and Chen, J., 2013, Finer resolution observation and monitoring of global land cover-First mapping results with Landsat TM and ETM+ data: International Journal of Remote Sensing, v. 34, no. 7, p. 2607-2654.

Gorelick, N., Hancher, M., Dixon, M., Ilyushchenko, S., Thau, D., and Moore, R., 2017, Google Earth Engine-Planetary-scale geospatial analysis for everyone: Remote Sensing of Environment, v. 202, p. 18-27.

Gumma, M., Thenkabail, P., Teluguntla, P., Oliphant, A., Xiong, J., Congalton, R., Yadav, K., Phalke, A., and Smith, C., 2017, GFSAD30SAAFGIRCE v001-Global food security-support analysis data (GFSAD) cropland extent 2015 South Asia, Afghanistan, Iran 30 m: U.S. Geological Survey-National Aeronautics and Space Administration Land Processes Distributed Active Archive Center website, https://doi.org/10.5067/ MEaSUREs/GFSAD/GFSAD30SAAFGIRCE.001.

Gumma, M.K., Nelson, A., Thenkabail, P.S., and Singh, A.N., 2011a, Mapping rice areas of South Asia using MODIS multitemporal data: Journal of Applied Remote Sensing, v. 5, 26 p., https://doi.org/10.1117/1.3619838.
Gumma, M.K., Thenkabail, P.S., Hideto, F., Nelson, A., Dheeravath, V., Busia, D., and Rala, A., 2011b, Mapping irrigated areas of Ghana using fusion of $30 \mathrm{~m}$ and $250 \mathrm{~m}$ resolution remote-sensing data: Remote Sensing, v. 3, no. 4, p. 816-835.

Gumma, M.K., Thenkabail, P.S., Maunahan, A., Islam, S., and Nelson, A., 2014, Mapping seasonal rice cropland extent and area in the high cropping intensity environment of Bangladesh using MODIS $500 \mathrm{~m}$ data for the year 2010: ISPRS Journal of Photogrammetry and Remote Sensing, v. 91, p. 98-113, https://doi.org/10.1016/j. isprsjprs.2014.02.007.

Gumma, M.K., Thenkabail, P.S., Muralikrishna, I.V., Velpuri, M.N., Gangadhararao, P.T., Dheeravath, V., Biradar, C.M., Acharya Nalan, S., and Gaur, A., 2011c, Changes in agricultural cropland areas between a water-surplus year and a water-deficit year impacting food security, determined using MODIS $250 \mathrm{~m}$ time-series data and spectral matching techniques, in the Krishna River basin (India): International Journal of Remote Sensing, v. 32, no. 12, p. 3495-3520, https://doi.org/10.1080/01431161003749485.

Gumma, M.K., Thenkabail, P.S., Teluguntla, P., Rao, M.N., Mohammed, I.A., and Whitbread, A.M., 2016, Mapping rice-fallow cropland areas for short-season grain legumes intensification in South Asia using MODIS $250 \mathrm{~m}$ timeseries data: International Journal of Digital Earth, v. 9, no. 10, p. 981-1003, https://doi.org/10.1080/17538947.2016 .1168489 .

Gumma, M.K., Thenkabail, P.S., Teluguntla, P.G., Oliphant, A., Xiong, J., Giri, C., Pyla, V., Dixit, S., and Whitbread, A.M., 2019, Agricultural cropland extent and areas of South Asia derived using Landsat satellite 30-m time-series big-data using random forest machine learning algorithms on the Google Earth Engine cloud: GIScience \& Remote Sensing, v. 57, no. 3, p. 1548-1603, https://doi.org/10.1080/ 15481603.2019.1690780.

Han, W., Yang, Z., Di, L., and Mueller, R., 2012, CropScape—A Web service based application for exploring and disseminating US conterminous geospatial cropland data products for decision support: Computers and Electronics in Agriculture, v. 84, p. 111-123, https://doi.org/10.1016/j.compag.2012.03.005.

Herold, M., Mayaux, P., Woodcock, C.E., Baccini, A., and Schmullius, C., 2008, Some challenges in global land cover mapping-An assessment of agreement and accuracy in existing $1 \mathrm{~km}$ datasets: Remote Sensing of Environment, v. 112, no. 5, p. 2538-2556.

Herold, M., Woodcock, C., di Gregorio, A., Mayaux, P., Belward, A., Latham, J., and Schmullius, C.C., 2006, A joint initiative for harmonization and validation of land cover datasets: IEEE Transactions on Geoscience and Remote Sensing, v. 44, no. 7, p. 1719-1727. 
High Level Panel of Experts, 2020, Impacts of COVID-19 on food security and nutrition-Developing effective policy responses to address the hunger and malnutrition pandemic: Rome, September 2020, Committee on World Food Security, High Level Panel of Experts on Food Security and Nutrition, https://www.fao.org/3/cb1000en/cb1000en.pdf.

Hoekstra, A.Y., and Mekonnen, M.M., 2012, The water footprint of humanity: Proceedings of the National Academy of Sciences of the United States of America (PNAS), v. 109, no. 9, p. 3232-3237.

Huang, J.-K., Wei, W., Cui, Q., and Xie, W., 2017, The prospects for China's food security and imports-Will China starve the world via imports?: Journal of Integrative Agriculture, v. 16, no. 12, p. 2933-2944, https://doi.org/10.1016/S20953119(17)61756-8.

Huang, Z., Hejazi, M., Tang, Q., Vernon, C.R., Liu, Y., Chen, M., and Calvin, K., 2019, Global agricultural green and blue water consumption under future climate and land use changes: Journal of Hydrology, v. 574, p. 242-256, https:// doi.org/10.1016/j.jhydrol.2019.04.046.

Imani, M., and Ghassemian, H., 2015, Two dimensional linear discriminant analyses for hyperspectral data: Photogrammetric Engineering \& Remote Sensing, v. 81, no. 10 , p. $777-786$.

International Food Policy Research Institute, 2020, 2020 Global food policy report-Building inclusive food systems: International Food Policy Research Institute, 110 p., https://www.ifpri.org/publication/2020-global-foodpolicy-report-building-inclusive-food-systems.

Jensen, J., 2007, Remote sensing of the environment-An Earth resource perspective ( $2 \mathrm{~d}$ ed.): London, United Kingdom, Pearson, 544 p.

Jiang, H., Cooke, B., and Heerman, K.E.R., 2015, Outlook for U.S. Agricultural Trade: U.S. Department of Agriculture, Economic Research Service, Outlook for U.S. Agricultural Trade No. (AES-90), 17 p., https://www.ers.usda.gov/ publications/pub-details/?pubid $=35801$.

Johansson, R., Luebehusen, E., Morris, B., Shannon, H., and Meyer, S., 2015, Monitoring the impacts of weather and climate extremes on global agricultural production: Weather and Climate Extremes, v. 10, part A, p. 65-71, https://doi. org/10.1016/j.wace.2015.11.003.

Kaptué Tchuenté, A.T., Roujean, J.-L., and De Jong, S.M., 2011, Comparison and relative quality assessment of the GLC2000, GLOBCOVER, MODIS and ECOCLIMAP land cover data sets at the African continental scale: International Journal of Applied Earth Observation and Geoinformation, v. 13, no. 2, p. 207-219.
Kastner, T., Rivas, M.J.I., Koch, W., and Nonhebel, S., 2012, Global changes in diets and the consequences for land requirements for food: Proceedings of the National Academy of Sciences, v. 109, no. 18, p. 6868-6872.

Kayatz, B., Harris, F., Hillier, J., Adhya, T., Dalin, C., Nayak, D., Green, R.F., Smith, P., and Dangour, A.D., 2019, "More crop per drop"-Exploring India's cereal water use since 2005: Science of The Total Environment, v. 673, p. 207-217, https://doi.org/10.1016/j.scitotenv.2019.03.304.

Kranjčić, N., Medak, D., Župan, R., and Rezo, M., 2019, Support Vector Machine accuracy assessment for extracting green urban areas in towns: Remote Sensing, v. 11, no. 6, p. 655.

Lal, R., 2014, Societal value of soil carbon: Journal of Soil and Water Conservation, v. 69, no. 6, p. 186A-192A.

Lal, R., Griffin, M., Apt, J., Lave, L., and Morgan, M.G., 2004, Managing soil carbon: Science, v. 304, no. 5669, p. 393.

Lark, T.J., Mueller, R.M., Johnson, D.M., and Gibbs, H.K., 2017, Measuring land-use and land-cover change using the U.S. Department of Agriculture's cropland data layer-Cautions and recommendations: International Journal of Applied Earth Observation and Geoinformation, v. 62, p. 224-235, https://doi. org/10.1016/j.jag.2017.06.007.

Laso Bayas, J.C., Lesiv, M., Waldner, F., Schucknecht, A., Duerauer, M., See, L., Fritz, S., Fraisl, D., Moorthy, I., McCallum, I., Perger, C., Danylo, O., Defourny, P., Gallego, J., Gilliams, S., Akhtar, I.U.H., Baishya, S.J., Baruah, M., Bungnamei, K., Campos, A., Changkakati, T., Cipriani, A., Das, K., Das, K., Das, I., Davis, K.F., Hazarika, P., Johnson, B.A., Malek, Z., Molinari, M.E., Panging, K., Pawe, C.K., Pérez-Hoyos, A., Sahariah, P.K., Sahariah, D., Saikia, A., Saikia, M., Schlesinger, P., Seidacaru, E., Singha, K., and Wilson., J.W., 2017, A global reference database of crowdsourced cropland data collected using the Geo-Wiki platform: Scientific Data, v. 4, no. 1, 11 p.

Leroux, L., Jolivot, A., Bégué, A., Lo Seen, D., and Zoungrana, B., 2014, How reliable is the MODIS land cover product for crop mapping sub-Saharan agricultural landscapes?: Remote Sensing, v. 6, no. 9, p. 8541-8564.

Liu, X., Yu, L., Li, W., Peng, D., Zhong, L., Li, L., Xin, Q., Lu, H., Yu, C., and Gong, P., 2018, Comparison of country-level cropland areas between ESA-CCI land cover maps and FAOSTAT data: International Journal of Remote Sensing, v. 39, no. 20,15 p.

Loveland, T.R., Reed, B.C., Brown, J.F., Ohlen, D.O., Zhu, Z., Yang, L., and Merchant, J.W., 2000, Development of a global land cover characteristics database and IGBP DISCover from $1 \mathrm{~km}$ AVHRR data: International Journal of Remote Sensing, v. 21, nos. 6-7, p. 1303-1330. 
Makate, C., 2019, Effective scaling of climate smart agriculture innovations in African smallholder agriculture-A review of approaches, policy and institutional strategy needs: Environmental Science \& Policy, v. 96, p. 37-51, https://doi. org/10.1016/j.envsci.2019.01.014.

Massey, R., 2017, Satellite remote sensing of cropland characteristics in $30 \mathrm{~m}$ resolution-The first North American continental-scale classification on high performance computing platforms: Flagstaff, Northern Arizona University, Ph.D. dissertation, $255 \mathrm{p}$.

Massey, R., Sankey, T., Yadav, K., Congalton, R., Tilton, J., and Thenkabail, P., 2017a, GFSAD30NACE v001-Global food security-support analysis data (GFSAD) cropland extent 2010 North America 30 m: U.S. Geological Survey-National Aeronautics and Space Administration Land Processes Distributed Active Archive Center website, https://doi. org/10.5067/MEaSUREs/GFSAD/GFSAD30NACE.001.

Massey, R., Sankey, T.T., Congalton, R.G., Yadav, K., Thenkabail, P.S., Ozdogan, M., and Sánchez Meador, A.J., 2017b, MODIS phenology-derived, multi-year distribution of conterminous U.S. crop types: Remote Sensing of Environment, v. 198, p. 490-503, https://doi.org/10.1016/j. rse.2017.06.033.

Massey, R., Sankey, T.T., Yadav, K., Congalton, R.G., and Tilton, J.C., 2018, Integrating cloud-based workflows in continental-scale cropland extent classification: Remote Sensing of Environment, v. 219, p. 162-179, https://doi.org/10.1016/j. rse.2018.10.013.

Matton, N., Sepulcre Canto, G., Waldner, F., Valero, S., Morin, D., Inglada, J., Arias, M., Bontemps, S., Koetz, B., and Defourny, P., 2015, An automated method for annual cropland mapping along the season for various globallydistributed agrosystems using high spatial and temporal resolution time series: Remote Sensing, v. 7, no. 10, p. 13,208-13,232.

Mekonnen, M.M., and Hoekstra, A.Y., 2014, Water footprint benchmarks for crop production-A first global assessment: Ecological Indicators, v. 46, p. 214-223, https://doi. org/10.1016/j.ecolind.2014.06.013.

Melgani, F., and Bruzzone, L., 2002, Support vector machines for classification of hyperspectral remote-sensing images: Toronto, Ontario, Canada, IEEE International Geoscience and Remote Sensing Symposium, v. 1, p. 506-508, https://doi. org/10.1016/j.ecolind.2014.06.013.

Molotoks, A., Stehfest, E., Doelman, J., Albanito, F., Fitton, N., Dawson, T.P., and Smith, P., 2018, Global projections of future cropland expansion to 2050 and direct impacts on biodiversity and carbon storage: Global Change Biology, v. 24, no. 12, p. 5895-5908, https://doi.org/10.1111/gcb.14459.
Monfreda, C., Ramankutty, N., and Foley, J.A., 2008, Farming the planet-2. Geographic distribution of crop areas, yields, physiological types, and net primary production in the year 2000: Global Biogeochemical Cycles, v. 22, 10 p., https:// doi.org/10.1029/2007GB002947.

Mountrakis, G., Im, J., and Ogole, C., 2011, Support vector machines in remote sensing - A review: ISPRS Journal of Photogrammetry and Remote Sensing, v. 66, no. 3, p. 247-259.

Nabil, M., Zhang, M., Bofana, J., Wu, B., Stein, A., Dong, T., Zeng, H., and Shang, J., 2020, Assessing factors impacting the spatial discrepancy of remote sensing based cropland products - A case study in Africa: International Journal of Applied Earth Observation and Geoinformation, v. 85, 14 p., https://doi.org/10.1016/j.jag.2019.102010.

National Aeronautics and Space Administration; Japan's Ministry of Economy, Trade, and Industry's Japan Spacesystems; and United States' and Japan's ASTER Science Team, 2019, ASTGTM v003-ASTER Global digital elevation model 1 arc second: U.S. Geological Survey-National Aeronautics and Space Administration Land Processes Distributed Active Archive Center website, accessed June 2021 at https://doi.org/10.5067/ASTER/ ASTGTM.003.

Nemani, R., Votava, P., Michaelis, A., Melton, F., and Milesi, C., 2011, Collaborative supercomputing for global change science: Eos, Transactions, American Geophysical Union, v. 92, no. 13, p. 109-110.

Niedertscheider, M., Kastner, T., Fetzel, T., Haberl, H., Kroisleitner, C., Plutzar, C., and Erb, K.-H., 2016, Mapping and analysing cropland use intensity from a NPP perspective: Environmental Research Letters, v. 11, no. 1, $12 \mathrm{p}$.

Nuccio, M.L., Paul, M., Bate, N.J., Cohn, J., and Cutler, S.R., 2018, Where are the drought tolerant crops? An assessment of more than two decades of plant biotechnology effort in crop improvement: Plant Science, v. 273, p. 110-119, https://doi.org/10.1016/j.plantsci.2018.01.020.

Odegard, I.Y.R., and van der Voet, E., 2014, The future of food-Scenarios and the effect on natural resource use in agriculture in 2050: Ecological Economics, v. 97, p. 51-59.

Oliphant, A., Thenkabail, P., Teluguntla, P., Xiong, J., Congalton, R., Yadav, K., Massey, R., Gumma, M., and Smith, C., 2017, GFSAD30SEACE v001—Global food security-support analysis data (GFSAD) Cropland Extent 2015 Southeast and Northeast Asia 30 m: U.S. Geological Survey-National Aeronautics and Space Administration Land Processes Distributed Active Archive Center website, https://doi.org/10.5067/MEaSUREs/GFSAD/ GFSAD30SEACE.001 
Oliphant, A.J., Thenkabail, P.S., Teluguntla, P., Xiong, J., Gumma, M.K., Congalton, R.G., and Yadav, K., 2019, Mapping cropland extent of Southeast and Northeast Asia using multi-year time-series Landsat 30-m data using a random forest classifier on the Google Earth Engine cloud: International Journal of Applied Earth Observation and Geoinformation, v. 81, p. 110-124, https://doi.org/10.1016/j. jag.2018.11.014.

Olofsson, P., Foody, G.M., Herold, M., Stehman, S.V., Woodcock, C.E., and Wulder, M.A., 2014, Good practices for estimating area and assessing accuracy of land change: Remote Sensing of Environment, v. 148, p. 42-57.

Osei-Owusu, A.K., Kastner, T., de Ruiter, H., Thomsen, M., and Caro, D., 2019, The global cropland footprint of Denmark's food supply 2000-2013: Global Environmental Change, v. 58, 13 p., https://doi.org/10.1016/j.gloenvcha.2019.101978.

Ozdogan, M., and Gutman, G., 2008, A new methodology to map irrigated areas using multi-temporal MODIS and ancillary data-An application example in the continental US: Remote Sensing of Environment, v. 112, no. 9, p. 3520-3537.

Peña-Arancibia, J.L., McVicar, T.R., Paydar, Z., Li, L., Guerschman, J.P., Donohue, R.J., Dutta, D., Podger, G.M., van Dijk, A.I.J.M., and Chiew, F.H.S., 2014, Dynamic identification of summer cropping irrigated areas in a large basin experiencing extreme climatic variability.: Remote Sensing of Environment, v. 154, p. 139-152.

Pérez-Hoyos, A., Rembold, F., Kerdiles, H., and Gallego, J., 2017, Comparison of global land cover datasets for cropland monitoring: Remote Sensing, v. 9, no. 1118, 24 p., https:/doi. org/10.3390/rs9111118.

Phalke, A., Ozdogan, M., Thenkabail, P., Congalton, R., Yadav, K., Massey, R., Teluguntla, P., Poehnelt, J., and Smith, C., 2017, GFSAD30EUCEARUMECE v001Global food security-support analysis data (GFSAD) cropland extent 2015 Europe, Central Asia, Russia, Middle East 30 m: U.S. Geological Survey-National Aeronautics and Space Administration Land Processes Distributed Active Archive Center website, https://doi.org/10.5067/ MEaSUREs/GFSAD/GFSAD30EUCEARUMECE.001.

Phalke, A.R., and Özdoğan, M., 2018, Large area cropland extent mapping with Landsat data and a generalized classifier: Remote Sensing of Environment, v. 219, p. 180-195.

Phalke, A.R., Özdoğan, M., Thenkabail, P.S., Erickson, T., Gorelick, N., Yadav, K., and Congalton, R.G., 2020, Mapping croplands of Europe, Middle East, Russia, and Central Asia using Landsat, Random Forest, and Google Earth Engine: ISPRS Journal of Photogrammetry and Remote Sensing, v. 167, p. 104-122.
Pittman, K., Hansen, M.C., Becker-Reshef, I., Potapov, P.V., and Justice, C.O., 2010, Estimating global cropland extent with multi-year MODIS data: Remote Sensing, v. 2, no. 7, p. 1844-1863.

Portmann, F.T., Siebert, S., and Döll, P., 2010, MIRCA2000Global monthly irrigated and rainfed crop areas around the year 2000 — A new high-resolution data set for agricultural and hydrological modeling: Global Biogeochemical Cycles, v. 24, no. 1, 24 p., https://doi.org/10.1029/2008GB003435.

Potapov, P., Hansen, M.C., Kommareddy, I., Kommareddy, A., Turubanova, S., Pickens, A., Adusei, B., Tyukavina, A., and Ying, Q., 2020, Landsat analysis ready data for global land cover and land cover change mapping: Remote Sensing, v. 12, no. 3, 24 p.

Qiang, W., Niu, S., Liu, A., Kastner, T., Bie, Q., Wang, X., and Cheng, S., 2020, Trends in global virtual land trade in relation to agricultural products: Land Use Policy, v. 92, 12 p., https://doi. org/10.1016/j.landusepol.2019.104439.

Qiu, B., Zhong, M., Tang, Z., and Wang, C., 2014, A new methodology to map double-cropping croplands based on continuous wavelet transform: International Journal of Applied Earth Observation and Geoinformation, v. 26, p. 97-104.

Qiu, S., He, B., Zhu, Z., Liao, Z., and Quan, X., 2017, Improving Fmask cloud and cloud shadow detection in mountainous area for Landsats 4-8 images: Remote Sensing of Environment, v. 199, p. 107-119, https://doi.org/10.1016/j. rse.2017.07.002.

Ramankutty, N., Evan, A., Monfreda, C., and Foley, J.A., 2008, Farming the planet-1. Geographic distribution of global agricultural lands in the year 2000: Global Biogeochemical Cycles, v. 22, no. 1, 19 p., https://doi. org/10.1029/2007GB002952.

Relf-Eckstein, J.E., Ballantyne, A.T., and Phillips, P.W.B., 2019, Farming reimagined - A case study of autonomous farm equipment and creating an innovation opportunity space for broadacre smart farming: NJAS - Wageningen Journal of Life Sciences, vols. 90-91, 23 p., https://doi.org/10.1016/j. njas.2019.100307.

Salmon, J.M., Friedl, M.A., Frolking, S., Wisser, D., and Douglas, E.M., 2015, Global rain-fed, irrigated, and paddy croplands-A new high resolution map derived from remote sensing, crop inventories and climate data: International Journal of Applied Earth Observation and Geoinformation, v. 38, p. 321-334, https://doi.org/10.1016/j.jag.2015.01.014.

Sankey, T.T., Massey, R., Yadav, K., Congalton, R.G., and Tilton, J.C., 2018, Post-socialist cropland changes and abandonment in Mongolia: Land Degradation \& Development, v. 29, no. 9, p. 2808-2821, https://doi.org/10.1002/ldr.2997. 
See, L., Fritz, S., You, L., Ramankutty, N., Herrero, M., Justice, C., Becker-Reshef, I., Thornton, P., Erb, K., Gong, P., Tang, H., van der Velde, M., Ericksen, P., McCallum, I., Kraxner, F., and Obersteiner, M., 2015, Improved global cropland data as an essential ingredient for food security: Global Food Security, v. 4, p. 37-45, https://doi.org/10.1016/j.gfs.2014.10.004.

Shah, S.H., Angel, Y., Houborg, R., Ali, S., and McCabe, M.F., 2019, A Random Forest machine learning approach for the retrieval of leaf chlorophyll content in wheat: Remote Sensing, v. 11 , no. 8, 26 p.

Shi, K., Chen, Y., Yu, B., Xu, T., Li, L., Huang, C., Liu, R., Chen, Z., and Wu, J., 2016, Urban expansion and agricultural land loss in China-A multiscale perspective: Sustainability, v. 8, no. 8, $16 \mathrm{p}$.

Shikha, J., and Srinivasan, P.V., 1999, Grain price stabilization in India - Evaluation of policy alternatives: Agricultural Economics, v. 21, no. 1, p. 93-108, https://www.sciencedirect. com/science/article/abs/pii/S0169515099000171.

Siebert, S., and Döll, P., 2010, Quantifying blue and green virtual water contents in global crop production as well as potential production losses without irrigation: Journal of Hydrology, v. 384, nos. 3-4, p. 198-217, https://doi.org/10.1016/j. jhydrol.2009.07.031.

Smith, P., Gregory, P.J., van Vuuren, D., Obersteiner, M., Havlík, P., Rounsevell, M., Woods, J., Stehfest, E., and Bellarby, J., 2010, Competition for land: Philosophical Transactions of the Royal Society of London B-Biological Sciences, v. 365, no. 1554, p. 2941-2957.

Somkuti, P., Bösch, H., Feng, L., Palmer, P.I., Parker, R.J., and Quaife, T., 2020, A new space-borne perspective of crop productivity variations over the US Corn Belt: Agricultural and Forest Meteorology, v. 281, 11 p., https://doi.org/10.1016/j. agrformet.2019.107826.

Soulard, C.E., Acevedo, W., Auch, R.F., Sohl, T.L., Drummond, M.A., Sleeter, B.M., Sorenson, D.G., Kambly, S., Wilson, T.S., Taylor, J.L., Sayler, K.L., Stier, M.P., Barnes, C.A., Methven, S.C., Loveland, T.R., Headley, R., and Brooks, M.S., 2014, Land cover trends dataset, 1973-2000: U.S. Geological Survey Data Series 844, 10 p., https://doi.org/10.3133/ds844.

State Statistics Service of Ukraine, 2013, UKRSTAT: Ukraine official website, http://www.ukrstat.gov.ua/.

Story, M., and Congalton, R.G., 1986, Accuracy assessment-A user's perspective: Photogrammetric Engineering and Remote Sensing, v. 52, no. 3, p. 397-399.

Sukara, E., 2014, Tropical forest biodiversity to provide food, health and energy solution of the rapid growth of modern society: Procedia Environmental Sciences, v. 20, p. 803-808.
Tatsumi, K., Yamashiki, Y., Torres, M.A.C., and Taipe, C.L.R., 2015, Crop classification of upland fields using Random forest of time-series Landsat 7 ETM+ data: Computers and Electronics in Agriculture, v. 115, p. 171-179.

Teluguntla, P., Thenkabail, P., Xiong, J., Gumma, M., Congalton, R., Oliphant, A., Sankey, T., Poehnelt, J., Yadav, K., Massey, R., Phalke, A., and Smith, C., 2017a, GFSAD30AUNZCNMOCE v001-Global food securitysupport analysis data (GFSAD) cropland extent 2015 Australia, New Zealand, China, Mongolia 30 m: U.S. Geological Survey-National Aeronautics and Space Administration Land Processes Distributed Active Archive Center website, https://doi.org/10.5067/MEaSUREs/ GFSAD/GFSAD30AUNZCNMOCE.001.

Teluguntla, P., Thenkabail, P., Xiong, J., Gumma, M., Giri, C., Milesi, C., Ozdogan, M., Congalton, R., Tilton, J., Sankey, T., Massey, R., Phalke, A., and Yadav, K., 2016, GFSAD1KCM v001-Global food security support analysis data (GFSAD) crop mask 2010 global $1 \mathrm{~km}$ : U.S. Geological Survey-National Aeronautics and Space Administration Land Processes Distributed Active Archive Center website, https://doi.org/10.5067/MEaSUREs/ GFSAD/GFSAD1KCM.001.

Teluguntla, P., Thenkabail, P.S., Oliphant, A., Xiong, J., Gumma, M.K., Congalton, R.G., Yadav, K., and Huete, A., 2018, A 30-m Landsat-derived cropland extent product of Australia and China using random forest machine learning algorithm on Google Earth Engine cloud computing platform: ISPRS Journal of Photogrammetry and Remote Sensing, v. 144, p. 325-340, https://doi.org/10.5067/ MEaSUREs/GFSAD/GFSAD1KCM.001.

Teluguntla, P., Thenkabail, P.S., Xiong, J., Gumma, M.K., Congalton, R.G., Oliphant, A., Poehnelt, J., Yadav, K., Rao, M., and Massey, R., 2017b, Spectral matching techniques (SMTs) and automated cropland classification algorithms (ACCAs) for mapping croplands of Australia using MODIS 250-m time-series (2000-2015) data: International Journal of Digital Earth, v. 10, no. 9, p. 944-977, https://doi.org/10. 1080/17538947.2016.1267269.

Teluguntla, P., Thenkabail, P.S., Xiong, J., Gumma, M.K., Giri, C., Milesi, C., Ozdogan, M., Congalton, R.G., Tilton, J., Sankey, T.T., Massey, R., Phalke, A., and Yadav, K., 2015, Global food security support analysis data at nominal $1 \mathrm{~km}$ (GFSAD1km) derived from remote sensing in support of food security in the twenty-first century - Current achievements and future possibilities, chap. 6 in Thenkabail, P.S., ed., Land resources monitoring, modeling, and mapping with remote sensing, vol. II of Remote sensing handbook-Three volume set: Boca Raton, Fla., London, United Kingdom, and New York, N.Y., CRC Press/Taylor \& Francis Group, p. 131-160. 
Thenkabail, P., Knox, J., Ozdogan, M., Gumma, M., Congalton, R., Wu, Z., Milesi, C., Finkral, A., Marshall, M., Mariotto, I., You, S., Giri, C., and Nagler, P., 2016, GFSAD1KCD v001 - Global food security support analysis data (GFSAD) crop dominance 2010 global 1 km: U.S. Geological SurveyNational Aeronautics and Space Administration Land Processes Distributed Active Archive Center website, https://doi. org/10.5067/MEaSUREs/GFSAD/GFSAD1KCD.001.

Thenkabail, P.S., 2012, Special issue foreword-Global croplands: Photogrammetric Engineering and Remote Sensing, v. 78, no. 8, p. 787-788.

Thenkabail, P.S., 2015a, Remote sensing data characterization, classification, and accuracies - Advances of the last 50 years and a vision for the future, chap. 31 in Thenkabail, P.S., ed., Remotely sensed data characterization, classification, and accuracies, vol. I of Remote sensing handbook - Three volume set: Boca Raton, Fla., London, United Kingdom, and New York, N.Y., CRC Press/Taylor \& Francis Group, p. 625-662.

Thenkabail, P.S., 2015b, Remote sensing of land resourcesMonitoring, modeling, and mapping advances of the last 50 years and a vision for the future, chap. 26 in Thenkabail, P.S., ed., Land resources monitoring, modeling, and mapping with remote sensing, vol. II of Remote sensing handbookThree volume set: Boca Raton, Fla., London, United Kingdom, and New York, N.Y., CRC Press/Taylor \& Francis Group, p. 791-832.

Thenkabail, P.S., 2015c, Remote sensing of water resources, disasters, and urban-Monitoring, modeling, and mapping advances over last 50 years and a vision for the future, chap. 25 in Thenkabail, P.S., ed., Remote sensing of water resources, disasters, and urban studies, vol. III of Remote sensing handbook - Three volume set: Boca Raton, Fla., London, United Kingdom, and New York, N.Y., CRC Press/ Taylor \& Francis Group, p. 615-658.

Thenkabail, P.S., Aneece, I., Teluguntla, P., and Oliphant, A., 2021, Hyperspectral narrowband data propel gigantic leap in the Earth remote sensing: Photogrammetric Engineering \& Remote Sensing, v. 87, no. 7, p. 461-467, http://www.asprs.org/a/ publications/pers/2021journals/07-21_July_Flipping_Public.pdf.

Thenkabail, P.S., Biradar, C.M., Noojipady, P., Cai, X., Dheeravath, V., Li, Y., Velpuri, M., Gumma, M., and Pandey, S., 2007a, Sub-pixel area calculation methods for estimating irrigated areas: Sensors, v. 7, no. 11, p. 2519-2538, https:// doi.org/10.3390/s7112519.

Thenkabail, P.S., Biradar, C.M., Noojipady, P., Dheeravath, V., Gumma, M., Li, Y.J., Velpuri, M., and Gangalakunta, O.R.P., 2009a, Global irrigated area maps (GIAM) and statistics using remote sensing, in Thenkabail, P., Lyon, G.J., Biradar, C.M., and Turral, H., eds., Remote sensing of global croplands for food security: Boca Raton, Fla., London, United Kingdom, and New York, N.Y., CRC Press/Taylor \& Francis Group, p. 41-120.
Thenkabail, P.S., Biradar, C.M., Noojipady, P., Dheeravath, V., Li, Y., Velpuri, M., Gumma, M., Gangalakunta, O.R.P., Turral, H., Cai, X., Vithanage, J., Schull, M.A., and Dutta, R., 2009b, Global irrigated area map (GIAM), derived from remote sensing, for the end of the last millennium: International Journal of Remote Sensing, v. 30, no. 14, p. 3679-3733.

Thenkabail, P.S., GangadharaRao, P., Biggs, T.W., Krishna, M., and Turral, H., 2007b, Spectral matching techniques to determine historical land-use/land-cover (LULC) and irrigated areas using time-series 0.1-degree AVHRR pathfinder datasets: Photogrammetric Engineering \& Remote Sensing, v. 73, no. 10, p. 1029-1040.

Thenkabail, P.S., Hanjra, M.A., Dheeravath, V., and Gumma, M., 2010, A holistic view of global croplands and their water use for ensuring global food security in the 21st century through advanced remote sensing and non-remote sensing approaches: Remote Sensing, v. 2, no. 1, p. 211-261, https:// doi.org/10.3390/rs2010211.

Thenkabail, P.S., Hanjra, M.A., Dheeravath, V., and Gumma, M.K., 2011, Global croplands and their water use from remote sensing and nonremote sensing perspectives, chap. 16 in Qihao, W., ed., Advances in environmental remote sensing - Sensors, algorithms, and applications: Boca Raton, Fla., London, United Kingdom, and New York, N.Y., CRC Press/Taylor \& Francis Group, p. 383-419.

Thenkabail, P.S., Knox, J.W., Ozdogan, M., Gumma, M.K., Congalton, R.G., Wu, Z., Milesi, C., Finkral, A., Marshall, M., Mariotto, I., You, S., Giri, C., and Nagler, P., 2012, Assessing future risks to agricultural productivity, water resources and food security_-How can remote sensing help?: Photogrammetric Engineering and Remote Sensing, v. 78, no. 8, p. 773-782.

Thenkabail, P.S., and Wu, Z., 2012, An automated cropland classification algorithm (ACCA) for Tajikistan by combining Landsat, MODIS, and secondary data: Remote Sensing, v. 4, no. 10, p. 2890-2918, http://www.mdpi.com/20724292/4/10/2890.

Tian, S., Zhang, X., Tian, J., and Sun, Q., 2016, Random forest classification of wetland landcovers from multi-sensor data in the arid region of Xinjiang, China: Remote Sensing, v. 8, no. $11,14 \mathrm{p}$.

Tilman, D., Balzer, C., Hill, J., and Befort, B.L., 2011, Global food demand and the sustainable intensification of agriculture: Proceedings of the National Academy of Sciences, v. 108, no. 50, p. 20,260-20,264.

Tilton, J.C., Tarabalka, Y., Montesano, P.M., and Gofman, E., 2012, Best merge region-growing segmentation with integrated nonadjacent region object aggregation: IEEE Transactions on Geoscience and Remote Sensing, v. 50, no. 11, p. 4454-4467. 
Trade Commissioner Service, 2019, Overview of China's food and beverage market: Government of Canada, Trade Commissioner Service website, accessed November 2019 at https://www.tradecommissioner.gc.ca/china-chine/marketfacts-faits-sur-le-marche/0003012.aspx?lang=eng.

Tramberend, S., Fischer, G., Bruckner, M., and van Velthuizen, H., 2019, Our common cropland-Quantifying global agricultural land use from a consumption perspective: Ecological Economics, v. 157, p. 332-341, https://doi. org/10.1016/j.ecolecon.2018.12.005.

Tripathi, A., Tripathi, D.K., Chauhan, D.K., Kumar, N., and Singh, G.S., 2016, Paradigms of climate change impacts on some major food sources of the world-A review on current knowledge and future prospects: Agriculture, Ecosystems \& Environment, v. 216, p. 356-373.

United Nations [UN], 2018, Population Division-World urbanization prospects 2018: United Nations website, accessed August 2019 at https://population.un.org/wup/ Download/.

United Nations [UN], 2019, Population Division-World population prospects 2019: United Nations website, accessed August 2019 at https://population.un.org/wpp/.

U.S. Geological Survey and National Aeronautics and Space Administration [USGS and NASA], 2017, Release of GFSAD 30 meter cropland extent products: U.S. Geological Survey-National Aeronautics and Space Administration Land Processes Distributed Active Archive Center website, accessed June 2021 at https://lpdaac.usgs. gov/news/release-of-gfsad-30-meter-cropland-extentproducts/.

Vancutsem, C., Marinho, E., Kayitakire, F., See, L., and Fritz, S., 2013, Harmonizing and combining existing land cover/ land use datasets for cropland area monitoring at the African continental scale: Remote Sensing, v. 5, no. 1, p. 19-41, https://doi.org/10.3390/rs5010019.

Velpuri, N.M., Thenkabail, P.S., Gumma, M.K., Biradar, C., Dheeravath, V., Noojipady, P., and Yuanjie, L., 2009, Influence of resolution in irrigated area mapping and area estimation: Photogrammetric Engineering \& Remote Sensing, v. 75, no. 12, 13 p.

Vos, R., Martin, W., and Laborde, D., 2020, As COVID-19 spreads, no major concern for global food security yet: International Food Policy Research Institute, IFPRI Blog, Issue Post, March 10, 2020.

Waldner, F., Fritz, S., Di Gregorio, A., and Defourny, P., 2015, Mapping priorities to focus cropland mapping activitiesFitness assessment of existing global, regional and national cropland maps: Remote Sensing, v. 7, no. 6, p. 7959-7986, https://doi.org/10.3390/rs70607959.
Waldner, F., Fritz, S., Di Gregorio, A., Plotnikov, D., Bartalev, S., Kussul, N., Gong, P., Thenkabail, P., Hazeu, G., Klein, I., Löw, F., Miettinen, J., Dadhwal, V.K., Lamarche, C., Bontemps, S., and Defourny, P., 2016, A unified cropland layer at $250 \mathrm{~m}$ for global agriculture monitoring: Data, v. 1, no. 3, 13 p.

Wang, J., Zhao, Y., Li, C., Yu, L., Liu, D., and Gong, P., 2015, Mapping global land cover in 2001 and 2010 with spatialtemporal consistency at $250 \mathrm{~m}$ resolution: ISPRS Journal of Photogrammetry and Remote Sensing, v. 103, p. 38-47.

Wassmann, R., Villanueva, J., Khounthavong, M., Okumu, B.O., Vo, T.B.T., and Sander, B.O., 2019, Adaptation, mitigation and food security-Multi-criteria ranking system for climate-smart agriculture technologies illustrated for rainfed rice in Laos: Global Food Security, v. 23, p. 33-40, https://doi.org/10.1016/j. gfs.2019.02.003.

Whitcraft, A.K., Becker-Reshef, I., and Justice, C.O., 2015a, A framework for defining spatially explicit earth observation requirements for a global agricultural monitoring initiative (GEOGLAM): Remote Sensing, v. 7, no. 2, p. 1461-1481.

Whitcraft, A.K., Vermote, E.F., Becker-Reshef, I., and Justice, C.O., 2015b, Cloud cover throughout the agricultural growing season-Impacts on passive optical earth observations: Remote Sensing of Environment, v. 156, p. 438-447.

Wilkinson, J., 2015, Food security and the global agrifood system-Ethical issues in historical and sociological perspective: Global Food Security, v. 7, p. 9-14.

World Food Program USA, 2020, India: United Nations World Food Program website, https://www.wfpusa.org/countries/ india/.

Wu, W., Yu, Q., You, L., Chen, K., Tang, H., and Liu, J., 2018, Global cropping intensity gaps-Increasing food production without cropland expansion: Land Use Policy, v. 76, p. 515525, https://doi.org/10.1016/j.landusepol.2018.02.032.

Wu, X.D., Guo, J.L., Li, C.H., Shao, L., Han, M.Y., and Chen, G.Q., 2019, Global socio-hydrology-An overview of virtual water use by the world economy from source of exploitation to sink of final consumption: Journal of Hydrology, v. 573, p. 794-810, https://doi.org/10.1016/j.jhydrol.2019.03.080.

Wu, Z., Thenkabail, P.S., Mueller, R., Zakzeski, A., Melton, F., Johnson, L., Rosevelt, C., Dwyer, J., Jones, J., and Verdin, J.P., 2014a, Seasonal cultivated and fallow cropland mapping using MODIS-based automated cropland classification algorithm: Journal of Applied Remote Sensing, v. 8, no. 1, 17 p., https:// doi.org/10.1117/1.JRS.8.083685.

Wu, Z., Thenkabail, P.S., and Verdin, J.P., 2014b, Automated cropland classification algorithm (ACCA) for California using multi-sensor remote sensing: Photogrammetric Engineering \& Remote Sensing, v. 80, no. 1, p. 81-90. 
Würtenberger, L., Koellner, T., and Binder, C.R., 2006, Virtual land use and agricultural trade-Estimating environmental and socio-economic impacts: Ecological Economics, v. 57, no. 4, p. 679-697.

Xie, Y., Lark, T.J., Brown, J.F., and Gibbs, H.K., 2019, Mapping irrigated cropland extent across the conterminous United States at $30 \mathrm{~m}$ resolution using a semi-automatic training approach on Google Earth Engine: ISPRS Journal of Photogrammetry and Remote Sensing, v. 155, p. 136-149, https://doi.org/10.1016/j. isprsjprs.2019.07.005.

Xiong, J., Thenkabail, P., Tilton, J., Gumma, M., Teluguntla, P., Congalton, R., Yadav, K., Dungan, J., Oliphant, A., Poehnelt, J., Smith, C., and Massey, R., 2017a, GFSAD30AFCE v001Global food security-support analysis data (GFSAD) cropland extent 2015 Africa 30 m: U.S. Geological Survey-National Aeronautics and Space Administration Land Processes Distributed Active Archive Center website, https://doi. org/10.5067/MEaSUREs/GFSAD/GFSAD30AFCE.001.

Xiong, J., Thenkabail, P.S., Gumma, M.K., Teluguntla, P., Poehnelt, J., Congalton, R.G., Yadav, K., and Thau, D., 2017b, Automated cropland mapping of continental Africa using Google Earth Engine cloud computing: ISPRS Journal of Photogrammetry and Remote Sensing, v. 126, p. 225-244, https://doi.org/10.1016/j.isprsjprs.2017.01.019.

Xiong, J., Thenkabail, P.S., Tilton, J.C., Gumma, M.K., Teluguntla, P., Oliphant, A., Congalton, R.G., Yadav, K., and Gorelick, N., 2017c, Nominal 30-m cropland extent map of continental Africa by integrating pixel-based and object-based algorithms using Sentinel-2 and Landsat-8 data on Google Earth Engine: Remote Sensing, v. 9, no. 10, 27 p., https://doi.org/10.3390/rs9101065.

Xu, Y., Yu, L., Feng, D., Peng, D., Li, C., Huang, X., Lu, H., and Gong, P., 2019, Comparisons of three recent moderate resolution African land cover datasets-CGLS-LC100, ESA-S2-LC20, and FROM-GLC-Africa30: International Journal of Remote Sensing, v. 40, no. 16, p. 6185-6202.

Xu, Y., Yu, L., Zhao, F.R., Cai, X., Zhao, J., Lu, H., and Gong, P., 2018, Tracking annual cropland changes from 1984 to 2016 using time-series Landsat images with a change-detection and post-classification approach-Experiments from three sites in Africa: Remote Sensing of Environment, v. 218, p. 13-31, https://doi.org/10.1016/j.rse.2018.09.008.

Yadav, K., 2019, Accuracies, errors, and uncertainties of global cropland products: Durham, University of New Hampshire, Ph.D. dissertation, 217 p., accessed November 2019 at https://scholars.unh.edu/dissertation/2465.

Yadav, K., and Congalton, R.G., 2018, Accuracy assessment of global food security-support analysis data (GFSAD) cropland extent maps produced at three different spatial resolutions: Remote Sensing, v. 10, no. 11, 28 p.
Yadav, K., and Congalton, R.G., 2019, Correction-Yadav. K. and Congalton. R. Accuracy assessment of global food securitysupport analysis data (GFSAD) cropland extent maps produced at three different spatial resolutions. Remote Sens. 2018, 10, 1800: Remote Sensing, v. 11, no. 6, 7 p.

Yu, L., Wang, J., Clinton, N., Xin, Q., Zhong, L., Chen, Y., and Gong, P., 2013a, FROM-GC-30 m global cropland extent derived through multisource data integration: International Journal of Digital Earth, v. 6, no. 6, p. 521-533.

Yu, L., Wang, J., and Gong, P., 2013b, Improving $30 \mathrm{~m}$ global land-cover map FROM-GLC with time series MODIS and auxiliary data sets - A segmentation-based approach: International Journal of Remote Sensing, v. 34, no. 16, p. 5851-5867.

Yu, Q., Hu, Q., van Vliet, J., Verburg, P.H., and Wu, W., 2018, GlobeLand30 shows little cropland area loss but greater fragmentation in China: International Journal of Applied Earth Observation and Geoinformation, v. 66, p. 37-45, https://doi.org/10.1016/j.jag.2017.11.002.

Zhang, G., Xiao, X., Biradar, C.M., Dong, J., Qin, Y., Menarguez, M.A., Zhou, Y., Zhang, Y., Jin, C., Wang, J., Doughty, R.B., Ding, M., and Moore, B., III, 2017, Spatiotemporal patterns of paddy rice croplands in China and India from 2000 to 2015: Science of the Total Environment, v. 579, p. 82-92, https://doi. org/10.1016/j.scitotenv.2016.10.223.

Zhang, G., Xiao, X., Dong, J., Kou, W., Jin, C., Qin, Y., Zhou, Y., Wang, J., Menarguez, M.A., and Biradar, C., 2015, Mapping paddy rice planting areas through time series analysis of MODIS land surface temperature and vegetation index data: ISPRS Journal of Photogrammetry and Remote Sensing, v. 106, p. 157-171.

Zhang, Z., Ma, X., and Zhong, J., 2015, Single-pixel imaging by means of Fourier spectrum acquisition: Nature Communications, v. 6, 6 p., https://doi.org/10.1038/ncomms7225.

Zheng, B., Myint, S.W., Thenkabail, P.S., and Aggarwal, R.M., 2015, A support vector machine to identify irrigated crop types using time-series Landsat NDVI data: International Journal of Applied Earth Observation and Geoinformation, v. 34, p. 103-112.

Zhong, L., Gong, P., and Biging, G.S., 2014, Efficient corn and soybean mapping with temporal extendability-A multi-year experiment using Landsat imagery: Remote Sensing of Environment, v. 140, p. 1-13.

Zhong, Y., Giri, C., Thenkabail, P., Teluguntla, P., Congalton, R., Yadav, K., Oliphant, A., Xiong, J., Poehnelt, J., and Smith, C., 2017, GFSAD30SACE v001—Global food security-support analysis data (GFSAD) cropland extent 2015 South America 30 m: U.S. Geological Survey-National Aeronautics and Space Administration Land Processes Distributed Active Archive Center website, https://doi.org/10.5067/MEaSUREs/GFSAD/ GFSAD30SACE.001. 
Zhou, Y., Xiao, X., Qin, Y., Dong, J., Zhang, G., Kou, W., Jin, C., Wang, J., and Li, X., 2016, Mapping paddy rice planting area in rice-wetland coexistent areas through analysis of Landsat 8 OLI and MODIS images: International Journal of Applied Earth Observation and Geoinformation, v. 46, p. $1-12$.

Zhu, Z., 2019, Science of Landsat analysis ready data: Remote Sensing, v. 11, no. 18, 4 p.
Zhu, Z., Wang, S., and Woodcock, C.E., 2015, Improvement and expansion of the Fmask algorithm - Cloud, cloud shadow, and snow detection for Landsats 4-7, 8, and Sentinel 2 images: Remote Sensing of Environment, v. 159, p. 269-277, https:// doi.org/10.1016/j.rse.2014.12.014.

Zhu, Z., and Woodcock, C.E., 2014, Continuous change detection and classification of land cover using all available Landsat data: Remote Sensing of Environment, v. 144, p. 152-171. 
Moffett Field Publishing Service Center, California

Manuscript approved August 31, 2021

Edited by Taryn A. Lindquist

Illustration support by JoJo Mangano

Layout by Cory Hurd 

